"FUNGEMIA POR LEVEDURAS: PERFIS FENOTÍPICOS E MOLECULARES E SENSIBILIDADE ANTIFÚNGICA DE AMOSTRAS ISOLADAS NO HOSPITAL DAS CLÍNICAS DE BOTUCATU, SÃO PAULO". Biomédicas da Universidade de São Paulo para obtenção do título de Doutor em Ciências (Microbiologia)

São Paulo 2008 


\section{"FUNGEMIA POR LEVEDURAS: PERFIS FENOTÍPICOS E MOLECULARES E SENSIBILIDADE ANTIFÚNGICA DE AMOSTRAS ISOLADAS NO HOSPITAL DAS CLÍNICAS DE BOTUCATU, SÃO PAULO".}

Tese apresentada ao Instituto de Ciências Biomédicas da Universidade de São Paulo para obtenção do título de Doutor em Ciências

Área de Concentração: Microbiologia Orientadora: Prof. Dra. Claudete Rodrigues Paula

São Paulo 2008 
DADOS DE CATALOGAÇÃO NA PUBLICAÇÃO (CIP)

Serviço de Biblioteca e Informação Biomédica do

Instituto de Ciências Biomédicas da Universidade de São Paulo

(c) reprodução total

Ruiz, Luciana da Silva.

Fungemia por leveduras: perfis fenotípicos e moleculares e sensibilidade antifúngica de amostras isoladas no Hospital das Clínicas de Botucatu, São Paulo / Luciana da Silva Ruiz. -- São Paulo, 2008.

Orientador: Claudete Rodrigues Paula.

Tese (Doutorado) - Universidade de São Paulo. Instituto de Ciências Biomédicas. Departamento de Microbiologia. Área de concentração: Microbiologia. Linha de pesquisa: Leveduras patogênicas.

Versão do título para o inglês: Fungemia by yeasts: molecular and phenotypic profiles and susceptibility to antifungal agents of samples isolated at Hospital das Clínicas de Botucatu, São Paulo, Brazil.

Descritores: 1. Micologia aplicada 2. Micologia médica 3 . Candida 4. Fungemia 5. Perfil molecular 6. Sensibilidade antifúngica I. Paula, Claudete Rodrigues II. Universidade de São Paulo. Instituto de Ciências Biomédicas. Programa de Pós-Graduação em Microbiologia III. Título. 


\section{UNIVERSIDADE DE SÃO PAULO \\ INSTITUTO DE CIÊNCIAS BIOMÉDICAS}

Candidato(a): $\quad$ Luciana da Silva Ruiz.

Título da Tese: $\quad$ Fungemia por leveduras: perfis fenotípicos e moleculares e sensibilidade antifúngica de amostras isoladas no hospital das clínicas de Botucatu, São Paulo.

Orientador(a): $\quad$ Claudete Rodrigues Paula.

A Comissão Julgadora dos trabalhos de Defesa da Tese de Doutorado, em sessão pública realizada a ..................., considerou

\section{( ) Aprovado(a) ( ) Reprovado(a)}

Examinador(a): Assinatura:

Nome:

Instituição:

Examinador(a): Assinatura:

Nome:

Instituição:

Examinador(a): Assinatura:

Nome:

Instituição:

Examinador(a): Assinatura:

Nome:

Instituição:

Presidente: Assinatura:

Nome:

Instituição: 
"Louvado seja Deus na natureza, Mãe gloriosa e bela da Beleza,

E com todas as suas criaturas;

Pelo irmão Sol, o mais bondoso E glorioso irmão pelas alturas, $\mathrm{O}$ verdadeiro, o belo, que ilumina

Criando a pura glória - a luz do dia!

Louvado seja pelas irmãs Estrelas, Pela irmã Lua que derrama o luar, Belas, claras irmãs silenciosas E luminosas, suspensas no ar.

Louvado seja pela irmã Nuvem que há-de

Dar-nos a fina chuva que consola;

Pelo Céu azul e pela Tempestade;

Pelo irmão Vento, que rebrama e rola.

Louvado seja pela preciosa,

Bondosa água, irmã útil e bela, Que brota humilde. É casta e se oferece

A todo o que apetece o gosto dela.

Louvado seja pela maravilha Que rebrilha no Lume, o irmão ardente, Tão forte, que amanhece a noite escura,

E tão amável, que alumia a gente.

Louvado seja pelos seus amores, Pela irmã madre Terra e seus primores, Que nos ampara e oferta seus produtos, Árvores, frutos, ervas, pão e flores.

Louvado seja pelos que passaram Os tormentos do mundo dolorosos, E, contentes, sorrindo, perdoaram; Pela alegria dos que trabalham, Pela morte serena dos bondosos.

Louvado seja Deus na mãe querida, A natureza que fez bela e forte:

Louvado seja pela irmã Vida

Louvado seja pela irmã Morte.

Amém" 


\title{
DEDICATÓRIA
}

\author{
À DEUS que se fez presente em amor e alegria em meu \\ coração.
}

Aos meus queridos pais Moacir e Janete pelo apoio, incentivo e carinho.

Às minhas irmãs Adriana e Mariana pela força e carinho.

Ao meu querido Wagner, pelo amor, carinho, paciência e companheirismo.

Ao meu filho Caio, que me trouxe a maior de todas as alegrias: a de ser mãe.

Te amo! 
"Por vezes sentimos que aquilo que fazemos não é senão uma gota de água no mar. Mas o mar seria menor se lhe faltasse uma gota".

(Madre Teresa de Calcutá) 


\section{AGRADECIMENTO ESPECIAL}

À minha orientadora, Claudete Rodrigues Paula, os maiores e mais sinceros agradecimentos. Pelo constante incentivo, sempre indicando a direção a ser tomada nos momentos de maior dificuldade. Sua orientação e confiança foi capaz de me fazer trilhar por um crescimento científico e profissional.

Mais que orientadora, considero-a uma amiga, uma mãe. Toda minha admiração por seu brilhantismo acadêmico se torna secundária quando contemplo seu lado humanista. Generosa, paciente, amiga, corajosa, exigente, crítica, criativa, ousada, alegre e compreensiva.

Muito obrigada por tudo!! 


\section{AGRADECIMENTOS}

À Prof. Dra. Maria de Fátima Sugizaki, pelos ensinamentos e amizade que levarei sempre comigo.

\#

Aos Profs. Drs. Augusto César Montelli e Prof. Dr. Walderez Gambale pela ajuda no ingresso da pós-graduação, bem como pelo inestimável auxílio como pesquisadores.

$$
\text { \# }
$$

Ao Hospital das Clínicas da Faculdade de Medicina e o Instituto de Biociências da UNESP de Botucatu, SP, em especial aos Profs. Drs. Maria de Fátima Sugizaki, Augusto César Montelli e Maria de Lourdes Ribeiro de Souza da Cunha por cederem as amostras de leveduras para a realização desta pesquisa.

\#

Aos amigos Flávia, Ériques, Elza, Georgea, Shirlei, Adriana, Mauro, Estela, Lília, Marcos, Mônica, Amanda, Débora, Fernanda, Fabiana, Carina, Carlos, Paulinha, Satiko, pelas palavras amigas nos momentos difíceis e de alegria.

\#

As secretárias do Departamento de Microbiologia, Alice, Naíde e Aninha, pela pronta assistência e atenção que me foram dedicadas.

\#

Aos funcionários da Seção de Esterilização do Departamento de Microbiologia do ICB II USP, pela assistência, atenção e carinho prestados.

\#

Às bibliotecárias pelos esclarecimentos fornecidos durante a confecção da tese.

\#

Aos pacientes do Hospital das Clínicas de Botucatu, SP pela contribuição, sem a qual este trabalho não seria possível. 
À FAPESP, pelo apoio financeiro concedido para a realização desta pesquisa (Processo $n^{\circ}$ 03/08987-7). 


\section{RESUMO}

RUIZ, L.S. Fungemia por leveduras: perfis fenotípicos e moleculares e sensibilidade antifúngica de amostras isoladas no Hospital das Clínicas de Botucatu, São Paulo. 2008. 111f. Tese (Doutorado em Ciências) - Instituto de Ciências Biomédicas, Universidade de São Paulo, São Paulo, 2008.

Neste trabalho, estudamos 70 amostras de Candida provenientes de sangue de pacientes internados em Hospital Público de Botucatu, SP.. Os objetivos deste estudo foram: reidentificar os isolados em micoteca por método tradicional e "kit" comercial (API 20C); identificar por técnicas fenotípicas e genotípicas (PCR), a presença de C. dubliniensis; determinar e comparar as concentrações inibitórias mínimas (CIMs) das amostras frente ao cetoconazol, fluconazol, itraconazol, voriconazol, 5-fluorcitosina, anfotericina-B e caspofungina ("E-test"), utilizando como meio o RPMI+MOPS; caracterizar molecularmente as amostras seqüenciais do mesmo paciente pela técnica de PFGE; estudar o perfil genotípico de todos os isolados de C. albicans e C. parapsilosis, por meio da técnica de microsatélites e comparar os resultados com a técnica de PFGE. O nível de concordância entre o método tradicional e o sistema API 20C foi de 93\% . Nenhum isolado de $C$. dubliniensis foi identificado no estudo. Em relação à sensibilidade antifúngica, as amostras de C. parapsilosis, C. albicans, C. tropicalis e C. glabrata apresentaram alta porcentagem de amostras sensíveis às sete drogas testadas. As amostras de $C$. guilliermondii, C. krusei e C. tropicalis apresentaram uma menor porcentagem de sensibilidade em relação ao fluconazol, 5-fluorcitosina e itraconazol. Com relação a anfotericina $\mathrm{B}$, a maioria dos isolados mostrou-se sensível. A análise molecular pela técnica de PFGE, mostrou seis perfis de cariótipos diferentes em 24 isolados de pacientes que possuíam mais de uma amostra isolada. Em relação à comparação das técnicas de PFGE e microssatélites, observamos que a última mostrou maior poder discriminatório para as amostras de C. albicans e C. parapsilosis.

Palavras-chave: Levedura. Candida sp. Fungemia. Sensibilidade antifúngica. Perfil molecular 


\begin{abstract}
RUIZ, L.S. Fungemia by yeasts: molecular and phenotypic profiles and susceptibility to antifungal agents of samples isolated at Hospital das Clínicas de Botucatu, São Paulo, Brazil. 2008. 111f. Thesis (Microbiology) - Institute of Biomedical Science, University os São Paulo, SP Ciências Biomédicas, Universidade de São Paulo, São Paulo, 2008.
\end{abstract}

This study, which involved 70 samples of Candida obtained from the blood of patients admitted at the Hospital das Clínicas of the city of Botucatu, state of São Paulo, Brazil, was aimed to: identify the isolates in a culture collection by the traditional method and by a commercial kit (API 20C); identify the presence of $C$. dubliniensis by phenotypic and genotypic (PCR) techniques; determine and compare the minimum inhibitory concentrations (MICs) of these samples in regard to ketoconazole, fluconazole, itraconazole, voriconazole, 5-fluorocytosine, amphotericin B and caspofungin ("E-test"), using RPMI 1640 + MOPS medium; molecularly characterize sequential samples from the same patient by the PFGE technique; study the genotypic profile of all the isolates of $C$. albicans and C. parapsilosis by means of the microsatellite technique and compare the results with those obtained by the PFGE technique. The level of agreement between the traditional method and the API $20 \mathrm{C}$ system was $93 \%$. No isolate of $C$. dubliniensis was identified in the study. In relation to antifungal susceptibility, the strains of C. parapsilosis, C. albicans, C. tropicalis and C. glabrata presented a high percentage of samples susceptible to the seven drugs tested. The samples of C. guilliermondii, C. krusei and $C$. tropicalis presented a lower percentage of susceptibility in regard to, fluconazole, 5fluorocytosine and itraconazole. Most of the isolates were susceptible to amphotericin B. The molecular analysis by the PFGE technique revealed six different karyotype profiles among 24 sequential samples. In the comparison between the PFGE and microsatellite techniques, the latter showed a greater discriminatory power for $C$. albicans and $C$. parapsilosis.

Key words: yeasts, Candida sp., fungemia, antifungal susceptibility, molecular profile. 


\section{LISTA DE ILUSTRAÇÕES}

Figura 1 - Esquema metodológico da fita de "Etest" (antifúngicos $=\mu \mathrm{g} / \mathrm{mL}) . \quad 40$

Figura 2 - Amplificação do fragmento de $175 \mathrm{pb}$ de 17 isolados de $C$. albicans, obtidos através da técnica de PCR utilizando-se primer CAL5/NL4CAL. Todas as amostras amplificaram o fragmento correspondente àquele de C. albicans. A - linha 1 padrão de peso molecular; linha 2 C. albicans ATCC 64548; linha 2 C. dubliniensis ATCC 777; linhas de 5 a 16 isolados em estudo; linha 17 controle negativo. B - linha 18 padrão de peso molecular; linha 19 C. albicans ATCC 64548; linha 20 C. dubliniensis ATCC 777; linhas 21 - 25 isolados estudados; linha 26 controle negativo.

Figura 3 - Cariótipos eletroforéticos de amostras de Candida isoladas do mesmo paciente (sangue). S: Padrão de peso molecular (Saccharomyces cerevisiae) (Kb); linhas 1-2: paciente 1; linhas 3-4: paciente 2; linhas 5-10: paciente 3; linhas 11-12: paciente 4; linhas 13-14: paciente 5; linhas 15-16: paciente 6; linhas 17-19: paciente 7; linhas 20-21: paciente 8; linhas 22-24: paciente 9 .

Figura 4 - Cariótipos eletroforéticos de 17 amostras de C. albicans isoladas de sangue. S: Padrão de peso molecular (Saccharomyces cerevisiae) (Kb); linhas 1-17: amostras de C. albicans...

Figura 5 - Cariótipos eletroforéticos de 29 amostras de C. parapsiolosis isoladas de sangue. S: Padrão de peso molecular (Saccharomyces cerevisiae) (Kb); linhas 1-17: amostras de C. parapsilosis..................................................... 


\section{LISTA DE TABELAS}

Tabela 1 - Interpretação do comportamento de cepas de Candida sp, segundo normas do CLSI (M27A2-2002), frente a concentração dos antifúngicos $\mu \mathrm{g} / \mathrm{mL}$

Tabela 2 - Locus microssatélites para caracterização de C. albicans, primers e descrição.

Tabela 3 - Locus microssatélites para caracterização de C. parapsilosis, primers e descrição.

Tabela 4 - Identificação de 70 leveduras do gênero Candida pelo método tradicional e sistema API 20C

Tabela 5 - Sensibilidade das espécies de Candida isoladas de sangue de pacientes internados no Hospital das Clinicas de Botucatu, São Paulo, frente aos antifúngicos estudados.

Tabela 6 - Sensibilidade in vitro de Candida isoladas de sangue frente a sete antifúngicos através do método comercial Etest (CIM $\mu \mathrm{g} / \mathrm{mL}$ )

Tabela 7 - Cariótipos obtidos das amostras de Candida associadas com o mesmo paciente.

Tabela 8 - Comprimentos de pares de bases, pela análise de PCR, de 17 isolados de Candida albicans, empregando-se os "primers" CEF3 e ERK1......

Tabela 9 - Comprimentos de pares de bases, pela análise de PCR, de 17 isolados de Candida albicans, empregando-se os "primers" CDC3, EF3 e HIS3. 
Tabela 10 - Comprimentos de pares de bases, pela análise de PCR, de 29 isolados de Candida parapsilosis, empregando-se os "primers" $A$, $B$ e $D$

Tabela 11 - Cariótipos obtidos das amostras de Candida albicans.

Tabela 12 - Cariótipos obtidos das amostras de Candida parapsilosis.............. 


\section{SUMÁRIO}

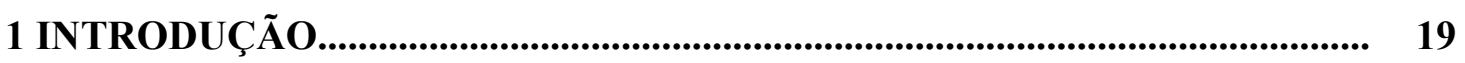

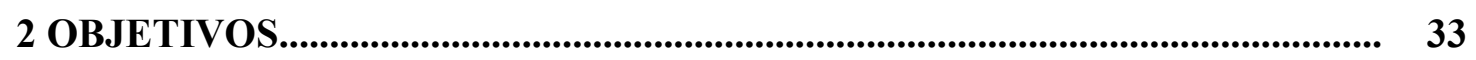

3 MATERIAL E MÉTODOS............................................................................. 35

3.1 Re-caracterização das Amostras de Leveduras..................................................... 35

3.2 Técnica para Diferenciação entre C. albicans $e$ C. dubliniensis............................ 35

3.2.1 Fenotipagem................................................................................................. 35

3.2.2 Genotipagem - Técnica de PCR........................................................................ 36

3.2.2.1 Extração do DNA............................................................................................ 36

3.2.2.2 Visualização do DNA Extraído......................................................................... 37

3.2.2.3 Reação de PCR...................................................................................................... 37

3.3 Teste de Sensibilidade aos Antifúngicos.............................................................. 38

3.3.2 Determinação da Concentração Inibitória Mínima (CIM) dos antifúngicos - kit "Etest" (AB Biodisk, Solna, Suécia).................................................................... 38

3.4 Perfis Genéticos das Amostras de Leveduras........................................................ 41

3.4.1 Cariotipagem - Eletroforese em Campo Pulsátil (PFGE)................................. 41

3.4.2 Téenica de Microssatélites......................................................................................... 43

3.4.2.1 Extração de DNA.................................................................................................... 43

3.4.2.2 Visualização do DNA Extraído........................................................................... 44

3.4.2.3 Análise dos Microssatélites.................................................................................. 45

3.4.2.4 Leitura e Interpretação dos Dados...................................................................... 48

3.4.3 Comparação entre as Técnicas de Microssatélites e Cariotipagem Aplicadas as Amostras de C. albicans e $C$. parapsilosis.............................................. 48

3.4.3.1 Análise Estatística.................................................................................................... 48 
4.1 Re-caracterização das Amostras de Leveduras..................................................... 51

4.2 Diferenciação entre $C$. albicans e $C$. dubliniensis.............................................. 51

4.3 Sensibilidade Antifúngica............................................................................... 54

4.4 Perfis Genéticos de Amostras de Leveduras.................................................... 59

4.4.1 Cariotipagem (Eletroforese em Campo Pulsátil) - Amostras Sequenciais... 59

4.4.2 Comparação entre as Técnicas de Microssatélites e Cariotipagem

Aplicadas as Amostras de $C$. albicans e $C$. parapsilosis.......................................... 62

4.4.2.1 Técnica de microssatélites................................................................................. 62

4.4.2.2 Técnica de PFGE............................................................................................... 66

4.5 Comparação entre os Perfis Genotípicos e Sensibilidade Antifúngica............. 70

5 DISCUSSÃO

5.1 Re-caracterização das Amostras de Leveduras...................................................... 72

5.2 Diferenciação entre $C$. albicans e $C$. dubliniensis................................................ 73

5.3 Sensibilidade Antifúngica........................................................................... 75

5.4 Perfis Genéticos de Amostras de Leveduras....................................................... 79

5.4.1 Cariotipagem (Eletroforese em Campo Pulsátil) - Amostras Sequenciais... 79

5.4.2 Comparação entre as Técnicas de Microssatélites e Cariotipagem

Aplicadas as Amostras de $C$. albicans e $C$. parapsilosis................................................. 81

6 CONCLUSÕES...................................................................................................... 86

REFERÊNCIAS BIBLIOGRÁFICAS.................................................................... 90

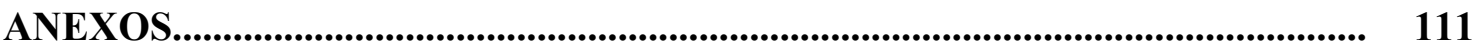


INTRODUC,ÃO 


\section{INTRODUÇÃO}

Nas últimas décadas houve inúmeros avanços na tecnologia disponível na área médica, representados pela introdução de diversos métodos diagnósticos e novas técnicas cirurgícas, disponibilidade de novos biomateriais para próteses, sondas e catéteres, avanços na quimioterapia de tumores, desenvolvimento de novos antibióticos e técnicas de transplante de órgãos. Estes avanços possibilitaram a maior sobrevida de doentes críticos (ARAUJO e COLOMBO, 1998).

Tais pacientes, frequentemente internados em unidades de terapia intensiva (UTIs), quando submetidos a procedimentos invasivos, quimioterapia ou antibioticoterapia, apresentam maior risco para aquisição de infecções nosocomiais, particularmente infecções fúngicas. Estes microorganismos, em outras épocas frequentemente considerados contaminantes ou colonizantes, passaram a ter caracteristicas oportunistas, tendo sido responsáveis por surtos de infecções hospitalares e também por causarem infecções de alta letalidade, particularmente nos imunossuprimidos, onde apresentam-se como infecções rapidamente progressivas, de difícil diagnóstico e refratárias a terapeutica (ARAUJO e COLOMBO, 1998; BONASSOLI e SVIDZINSKI, 2002; CAGGIANO et al., 2008).

A aquisição de infecções hospitalares depende de uma complexa interação entre hospedeiro susceptível e o agente infeccioso. Os fatores referentes ao patógeno incluem dose do inóculo suficiente para causar infecção, patogenicidade e infectividade. $O$ controle da infecção fúngica hospitalar requer o conhecimento do hospital como um complexo ecossistema (GHANNOUM e ABU-ELTEEN, 1990).

A colonização da pele ou da mucosa dos tratos gastrintestinal, genitourinário ou respiratório podem representar a primeira etapa no estabelecimento de infecções fúngicas sistêmicas. Estes sítios são considerados reservatórios de agentes responsáveis pela maioria de infecções hospitalares de origem endógena (JARVIS, 1995; WARREN e HAZEN, 1999).

A taxa de colonização em indivíduos hospitalizados é considerada mais alta do que na comunidade em geral. Procedimentos clínicos, a doença de base e uma 
permanência hospitalar prolongada contribuem para a rápida multiplicação de agentes colonizantes (JARVIS, 1996).

Com o objetivo de descrever a incidência e os padrões de infecções nosocomiais fúngicas, Yee-Chun Chen et al. (1997) realizaram um trabalho no Hospital da Universidade de Taiwan durante o período de 1981 à 1993. Verificaram que a taxa de infecção nosocomial fúngica aumentou de 0.9 infecções/1000 altas em 1981para 6.6 infecções/1000 altas em 1993. Foi observado um aumento das infecções na corrente sanguínea e do trato urinário.

Em um estudo multicêntrico no Chile, Silva et al. (2004) estudaram a prevalência de infecções fúngicas invasivas em 13 hospitais do país. No período de um ano um total de 130 pacientes com amostras fúngicas isoladas de sangue e outros sítios estéreis foram relatados. As infecções da corrente sanguínea representaram $83,5 \%$ do total de infecções nosocomiais, sendo que, todas as fungemias (61\% dos pacientes) foram ocasionadas por leveduras.

Nas últimas décadas, o número de espécies do gênero Candida de importância médica, vem aumentando progressivamente, constituindo um grupo dominante de infecções fúngicas nos hospitais (PAULA et al., 1999). Epécies de Candida são responsáveis por até $78 \%$ dos casos de infecções nosocomiais fúngicas (MAROL e YÜCESOY, 2007). Nota-se particularmente, um nítido aumento na incidência de infecções da corrente sangüínea causadas por estas leveduras principalmente por $C$. albicans (FRIDKIN e JARVIS, 1996; PFALLER, 1996; RODRIGUEZ-TUDELA e CUENCA-ESTRELA, 1999). Ela se tornou o quarto grupo de patógeno mais isolado de culturas de sangue (NG et al., 2000, YANG et al., 2003; FRIDKIN et al., 2006). A mortalidade associada à candidemia é de 20 a 40\%, e particularmente, de 18 a $80 \%$ em pacientes neutropênicos (PAGANO et al., 1999; WENZEL e GENNINGS, 2005).

Kossof et al. (1998) relatou que a taxa de candidemia de grupo neonatal em unidade de terapia intensiva aumentou de 2,5 no período de 1981-1985 para 4,6 a cada 1000 admissões no período de 1986-1990 e 28,5/1000 admissões de 1991-1995.

A Confederação Européia de Micologia Médica conduziu um estudo prospectivo e seqüencial em uma população hospitalar no período de setembro de 1997 a dezembro de 1999. Um total de 2089 casos de candidemia foram documentados em 106 instituições 
em sete países europeus. As taxas de candidemia foram de 0.20 a 0.38 por 1000 admissões (TORTORANO et al., 2004).

Acredita-se que a maioria dos casos de candidemia seja adquirida por via endógena, pela translocação do patógeno através do trato gastrointestinal, local onde há colonização por Candida spp em até $70 \%$ da população sadia. A maior parte das candidemias é precedida pelo evento da colonização pela mesma espécie de levedura, o que é considerado um fator de risco independente para o seu desenvolvimento (COLOMBO e GUIMARÃES, 2003). Métodos de genotipagem mostram a similaridade entre as cepas colonizantes e infectantes, comprovando a provável origem endógena da maioria das infecções por tais patógenos (NUCCI, 2001).

Infecções hematogênicas por Candida spp também podem ser adquiridas por via exógena, através do contato das mãos de profissionais de saúde, com pacientes portadores de cateteres vasculares em posição central, implante de próteses contaminadas, bem como pela administração parenteral de soluções contaminadas (WENZEL, 1995; PFALLER, 1996).

As espécies de Candida mais comumente isoladas de infecções sangüíneas, segundo vários autores, são: C. albicans, C. parapsilosis, C. tropicalis, C. guilliermondii, C. glabrata, C. krusei e C. lusitaniae (NG et al., 1999; LACAZ et al., 2002).

Embora $C$. albicans permaneça como a espécie de levedura mais comumente isolada de micoses superficiais e profundas, nos últimos anos, vem aumentando o número de infecções invasivas causadas por espécies não albicans (COLOMBO e GUIMARÃES, 2003).

Kao et al. (1999) observaram em hospitais das cidades de Atlanta e São Francisco (EUA), entre 1992 e 1993, que dos 837 casos de candidemias registrados, 47\% eram devido a espécies de Candida não albicans. Caggiano et al. (2008), realizaram um estudo observacional em hospitais na Itália durante 1998 a 2004. Os autores verificaram 155 casos de candidemia, sendo que $54,2 \%$ destes foram ocasionados por espécies não albicans. Outros trabalhos também têm relatado que de $40 \%$ à $50 \%$ das infecções nosocomiais sanguíneas são causadas por outras espécies de Candida (PFALLER et al., 1998; RUIZ et al., 2005). 
No Brasil, para avaliar a epidemiologia da candidemia, Colombo et al. (1999) realizaram um estudo em seis hopitais de São Paulo e Rio de Janeiro. Os autores registraram que dos 149 episódios de infecção, 63\% destes foram causados por espécies não-albicans. As espécies mais frequentemente identificadas foram C. albicans (37\%), C. parapsilosis (25\%), C. tropicalis (24\%), C. rugosa (5\%) e C. glabrata (4\%). Antunes et al. (2004), no período de agosto de 2002 a agosto de 2003, conduziram um estudo em hospital terciário de Porto Alegre, para determinar a distribuição das espécies de Candida associadas a candidemia. Os autores observaram que a maioria dos episódios $(51,6 \%)$ ocorreu por espécies outras que C. albicans.

Uma explicação para a emergência de espécies não albicans é a seleção de espécies menos susceptíveis pela pressão do uso de agentes antifúngicos. Diferenças espécie-específica na suscetibilidade ao fluconazol e outros agentes antifúngicos claramente existem e podem ser significativas para a emergência de espécies não albicans em algumas instituições (PFALLER et al., 1998).

Amostras de $C$. parapsilosis têm sido cada vez mais isoladas de sangue de pacientes hospitalizados (LEVIN et al., 1998; LEVY et al., 1998; MATSUMOTO et al., 2001), sendo que, nos EUA e Europa, é responsável por 7\% a 15\% das candidemias (VOSS et al., 1996). Fungemia devido a essa espécie de Candida geralmente está relacionada à presença de cateter venoso central bem como ao uso de nutrição parenteral (WEEMS, 1992).

Candida tropicalis possui considerável potencial biológico como agente oportunista, sendo relatada como o agente etiológico mais comum de candidemia em pacientes com neoplasias, sendo sua freqüência maior em leucemias e menor em tumores sólidos (WINGARD, 1995). Em países da América Latina, particularmente o Brasil, esta espécie é extremamente freqüente, mesmo entre pacientes não portadores de câncer, constituindo-se na segunda ou terceira principal causa de candidemia (COLOMBO et al., 1999; GOLDANI e MARIO, 2003).

Outra espécie não albicans que vem surgindo como importante patógeno hospitalar é $C$. glabrata, constituindo-se na segunda ou terceira espécie mais comum na maioria dos casos de candidemia relatados nos EUA e Europa (ABI-SAID et al., 1997). Isolados clínicos desta espécie apresentam menor sensibilidade ao fluconazol 
(DIEKEMA et al., 2002) conseqüentemente, um aumento nos índices de colonização/infecção por C. glabrata tem sido observado em diferentes grupos de pacientes expostos prolongadamente a este antifúngico (SAFRAN e DAWSON, 1997). No período de 1998 a 2000, Hajjeh et al. (2004), verificaram a incidência de infecções sanguíneas ocasionadas por espécies de Candida. Foram detectados 1143 casos, sendo que $C$. glabrata foi a segunda espécie mais isolada.

Existem variações geográficas significativas no padrão etiológico de infecções invasivas por Candida spp documentadas em vários países (COLOMBO e GUIMARÃES, 2003). Enquanto na América do Norte nota-se o predomínio de $C$. glabrata entre as espécies não albicans, na América do Sul, observa-se predomínio de $C$. parapsilosis e C. tropicalis (COLOMBO et al., 2003).

As peculiaridades apresentadas por diferentes espécies de Candida spp, do ponto de vista epidemiológico, justificam a necessidade de identificar-se às leveduras ao nível de espécie quando tais microrganismos estão associados a doenças sistêmicas. A identificação de leveduras é etapa fundamental para monitorização das taxas de infecção hospitalar bem como para identificação precoce de surtos de infecções por Candida (COLOMBO e GUIMARÃES, 2003).

Os métodos clássicos utilizados na identificação de patógenos leveduriformes, tais como Wicherman e técnicas auxanograficas, fazem uso de metodologias complexas e que consomem tempo (LIN et al., 1987). O aumento na incidência de infecções leveduriformes tem estimulado o desenvolvimento de sistemas comerciais automatizados e manuais acurados, tais como o Auxacolor, Mycotube, Candifast, Microring YT (MYT; Medical Wire \& Equipment Co., Victory Gardens, N.J.), o ID 32C (bioMérieux, Marcy l'Etoile, France) mais comumente utilizado em países da Europa, e o API 20C (bioMérieux Vitek, Inc., Hazelwood, Mo.), um sistema de identificação de levedura comumente utilizado nos EUA. Estes produtos devem possuir as seguintes características: (i) identificação rápida e precisa de leveduras isoladas de todos os tipos de espécimes clínicos; (ii) facilidade na manipulação e inoculação permitindo processamento rápido de mais de um isolado; e (iii) habilidade na identificação de isolados que são menos comumente recuperados de espécimes clínicos (RAMANI et al., 1998). 
O "kit" comercial para identificação de leveduras API 20C é um sistema miniaturizado do procedimento tradicional de assimilação de carboidratos, permitindo a identificação da levedura isolada dentro de 72 horas após incubação. É considerado por vários autores como um método de identificação rápido, de fácil execução e eficaz quando comparado ao método convencional e a outros sistemas (FENN et al., 1994; DAVEY et al., 1995; FRICKER-HIDALGO et al., 1996; RAMANI et al., 1998; ESPINEL-INGROFF et al., 1998).

Uma identificação rápida e eficaz de isolados leveduriformes torna-se cada vez mais importante uma vez que novos agentes antifúngicos com diferentes atividades junto a várias espécies vem sendo desenvolvidos e, além disso, leveduras patogênicas comuns, novas e emergentes associadas à infecções graves continuam a aumentar entre pacientes imunocomprometidos e neutropênicos (ESPINEL-INGROFF et al., 1998).

Um número progressivo de casos de doenças superficiais e invasivas relacionadas a espécies emergentes de Candida têm sido descrito, envolvendo isolamentos de C. kefyr, C. rugosa, C. famata, C. utilis, C. lipolytica, C. norvegensis, C. inconspícua, $C$. dubliniensis entre outras (COLEMAN et al., 1998).

Candida dubliniensis foi primeiramente identificada como uma nova espécie em 1995 em Dublin, na Irlanda (SULLIVAN et al., 1995). Desde então, infecções por esta levedura têm sido amplamente relatadas em um grande número de pacientes com AIDS e HIV positivos em todo mundo (MEYER et al., 2001).

No Brasil, C. dubliniensis foi isolada pela primeira vez em dois pacientes com AIDS no estado de São Paulo. Um paciente foi uma criança de três anos com candidíase orofaríngea (SANO et al., 2000) e o outro um paciente adulto (MILAN et al., 1999). Alves et al. (2001) relatou os primeiros três casos de isolamento de C. dubliniensis de pacientes com AIDS no Rio Grande do Sul.

Em indivíduos com AIDS e HIV positivos, amostras da espécie têm sido isoladas principalmente de cavidade oral (SULLIVAN et al., 1997; COLEMAN et al., 1997; JABRA-RITZ et al., 1999). No entanto, o isolamento em outros sítios anatômicos tem sido também relatado (SULLIVAN et al., 1995 e 1998), incluíndo face, feridas e trato respiratório (ODDS et al., 1998; POLACHECK et al., 2000). Um número limitado de amostras de $C$. dubliniensis tem sido também isolados do trato vaginal de mulheres HIV 
negativas com vaginite (Moran et al., 1997). Casos de fungemia por C. dubliniensis tem sido relatados em pacientes HIV negativos e positivos (SALESA et al., 2001; GOTTLIEB et al., 2001; TAN et al., 2002; SILVA et al., 2003).

A incidência de candidemia por $C$. dubliniensis ainda não é bem conhecida, principalmente devido à dificuldade de se distinguir esta espécie, uma vez que possui características morfológicas e bioquímicas similares a $C$. albicans (BRANDT et al., 2000). C. dubliniensis expressa o sorotipo A de C. albicans, e é capaz de formar tubos germinativos e abundantes clamidoconídios (SULLIVAN et al., 1995; COLEMAN et al., 1997; COLEMAN et al., 1997b; SULLIVAN e COLEMAN, 1998). Este alto grau de similaridade entre as duas espécies tem contribuído para a identificação de alguns isolados de C. dubliniensis como C. albicans (PINJON et al., 1998). Provavelmente, esta espécie tem estado presente na comunidade por um longo período de tempo, porém, sendo identificada como C. albicans (SCHORLING et al., 2000).

Assim, para uma maior compreensão dos aspectos clínicos e epidemiológicos desta espécie em infecções humanas, faz-se necessário o uso de testes rápidos e eficazes para identificação da mesma (PINJON et al., 1998). Desta maneira vários métodos de identificação de C. dubliniensis e discriminação de C.albicans têm sido relatados. Estes incluem: formação de clamidoconidios (SULLIVAN et al., 1995); padrão de assimilação de carboidratos (SALKIN et al., 1998); atividade de $\beta$-D-glucosidase (SCHOOFS et al., 1997); coloração colonial sobre diferentes meios tais como o "CHROMagar Candida", ágar Staib (STAIB e MORSCHHAUSER, 1999), ágar Niger (LEES e BARTON, 2003), ágar Tabaco (KHAN et al., 2004) entre outros; e, crescimento em ágar Sabouraud a $42^{\circ} \mathrm{C}$ (PINJON et al., 1998).

A importância de uma rápida identificação de patógenos, principalmente no contexto hospitalar, possivelmente tem contribuído para o desenvolvimento de meios diferenciais para a identificação presuntiva de leveduras (YÜCESOY e MAROL, 2003). Diferentes meios cromogênicos para isolamento e identificação de espécies de Candida estão disponíveis (LETSCHER et al., 2002). Estes meios baseiam-se na formação de diversas colorações coloniais com diferentes morfologias as quais resultam da clivagem de substratos cromogênicos por enzimas espécie-específicas (BAUTERS e NELIS, 2002). 
Atualmente, o meio cromogênico "CHROMagar Candida" tem sido utilizado, com resultados bem sucedidos, por vários pesquisadores na Europa e EUA para investigar a colonização oral por $C$. dubliniensis (SCHOOFS et al., 1997; SULLIVAN e COLEMAN, 1997), uma vez que a coloração verde escura de colônias sobre este meio, foi descrita como um marcador fenotípico desta espécie (COLEMAN et al., 1997).

Um marcador fenotípico também utilizado na identificação de $C$. dubliniensis e discriminação de C. albicans é a incapacidade deste organismo em crescer em altas temperaturas $\left(42^{\circ} \mathrm{C}\right)$. Por ser um teste barato e de fácil execução, gerando resultados após 48 horas de incubação com critérios claros de leitura, o mesmo tem sido utilizado por diferentes autores (KIRKPATRICK et al. 1998, TINTELNOT et al. 2000).

No entanto, variações individuais nas cepas têm sido relatadas para estas características fenotípicas (SULLIVAN et al., 1995; COLEMAN et al., 1997), fazendo-se necessário o estudo das características genotípicas.

Atualmente, existe uma ampla variedade de técnicas moleculares capazes de identificar C. dubliniensis, incluindo: testes de DNA utilizando análises com endonucleases de restrição, métodos baseados em eletroforese em campo pulsátil, testes de DNA utilizando sondas e métodos baseados no PCR. No entanto estes métodos possuem custo elevado, e dificilmente aplicados na rotina de identificação da maioria dos laboratórios de diagnóstico de microbiologia clínica (MANNARELLI e KURTZMAN 1998; KURZAI et al., 1999; SULLIVAN et al., 1999; PARK et al. 2000).

A identificação definitiva de C. dubliniensis ainda é um problema em laboratórios de rotina, portanto faz-se necessário o conhecimento das características fenotípicas e genotípicas do isolado para se obter uma etiologia final. Estudos da incidência realizados por laboratórios referência, também são necessários para uma melhor compreensão da epidemiologia desta nova espécie, principalmente na América do Sul, onde sua incidência ainda é pouco conhecida (COLOMBO et al., 2003).

Assim, é de fundamental importância identificar isolados clínicos corretamente durante o estágio inicial da infecção e principalmente se estiver relacionado com infecção hospitalar, em especial no caso de amostras de C. dubliniensis, por serem altamente resistentes ao fluconazol, e os isolados sensíveis têm a capacidade de desenvolver resistência à droga in vitro (SULLIVAN et al., 1997; MORAN et al., 1997). 
O uso terapêutico e profilático de agentes tais como anfotericina $\mathrm{B}$ e os azóis menos tóxicos, que são freqüentemente administrados por períodos prolongados, tem dado origem a casos alarmantes de resistência aos antifúngicos entre as espécies de Candida (WANGER et al., 1995; DROMER et al., 1997; DIAZ-GUERRA et al., 1998; LOZANO-CHIU et al., 1998; PFALLER et al., 1998a, 1998b).

Efeitos colaterais menos sérios e de fácil administração tem tornado os azólicos, drogas bastante atrativas. Com exceção do cetoconazol, o uso de imidazólicos está restrito ao tratamento de micoses superficiais, enquanto os triazólicos têm aplicações no tratamento de várias infecções fúngicas superficiais e sistêmicas (SHEEHAN et al., 1999). O fluconazol, uma droga menos tóxica que a anfotericina B, vem sendo a melhor alternativa como droga de escolha no tratamento de candidemia e várias infecções invasivas causadas por Candida em pacientes neutropênicos (REX et al., 2000). O aumento da ocorrência de espécies de Candida spp potencialmente resistentes às drogas azólicas (RICHARDS et al., 1999; PFALLER et al., 1999), levou ao desenvolvimento de novas drogas antifúngicas como o voriconazol que apresenta uma atividade de amplo espectro. O voriconazol é um novo derivado triazólico, mais solúvel que o fluconazol e vem mostrando resultados promissores contra espécies de Candida spp resistentes ao fluconazol (RUHNKE et al., 1997; PELLETIER et al., 2002).

$\mathrm{Na}$ busca de novos agentes antifúngicos com melhor tolerância e menor toxicidade do que a Anfotericina B, foi desenvolvida a caspofungina. Este antifúngico é uma equinocandina, e resultados de estudos revelam que o seu uso, em casos de candidiase invasiva e candidemia, tem equivalente eficácia a anfotericina $\mathrm{B}$, mas com efeitos tóxicos substancialmente menores (MORA-DUARTE et al., 2002).

No Brasil os principais grupos de antifúngicos utilizados contra Candida são os poliênicos, anfotericina B e os azólicos como cetoconazol e miconazol (imidazólicos) ou itraconazol, fluconazol e voriconazol (triazólicos).

O poliênico anfotericina B atua diretamente no ergosterol destruindo o gradiente de prótons da membrana fúngica (WHITE et al., 1998). Os azólicos interagem com a enzima lanosterol $14 \alpha$ demetilase, um citocromo P-450 que está envolvido na biossíntese do ergosterol. A inativação da enzima leva a acumulação de esteróis metilados, precursores do ergosterol, alterando a estrutura e função da membrana fúngica, causando 
significante inibição do crescimento do fungo (WHITE et al., 1998, GHANNOUM e RICE, 1999). As equinocandinas são drogas que inibem a síntese da beta-(1,3)-D glucana que é um componente da parede celular de muitos fungos filamentosos e de leveduras (ABUHAMMOUR et al., 2004).

A sensibilidade às drogas antifúngicas varia entre as diferentes espécies de Candida, o que realça a importância da identificação das espécies e determinação das CIMs dos antifúngicos (PFALLER et al., 1998c; SANDVEN et al., 1998; ST-GERMAIN et al., 2001).

Vários estudos de teste de sensibilidade aos antifúngicos tem sido realizados, uma vez que a incidência de infecções sérias com leveduras tem aumentado muito devido ao uso de agentes antimicrobianos de amplo espectro em pacientes imunocomprometidos e pacientes com AIDS (WEY et al., 1989; JARVIS et al., 1991).

Nos anos 90 tentou-se padronizar testes de sensibilidade antifúngica para leveduras para a obtenção de resultados rápidos, confiáveis e reprodutíveis que pudessem ser usados no monitoramento terapêutico (PFALLER e BARRY, 1994; SEWEL et al., 1994; COLOMBO et al., 1995a, 1995b; CORMICAN e PFALLER, 1996). A publicação do documento M27-A ("Clinical and Laboratory Standards Institute" - CLSI, 1997), foi um importante passo para a realização desses objetivos. Padronizou-se os métodos de macro e microdiluição em caldo para os testes de sensibilidade de Candida spp e Cryptococcus neoformans e definiu-se a interpretação de CIM (concentração inibitória mínima) para avaliar a eficácia da 5-fluorcitosina, fluconazol e itraconazol frente a isolados de Candida spp. A validação do método da microdiluição tem sido amplamente confirmado por estudos comparativos, embora vários parâmetros importantes, tais como o inoculo e o período de incubação, ainda estejam sendo discutidos (ARIKAN et al., 1997; CHRYSSANTHOU et al., 1997; CLANCY e NGUYEN, 1997; DAVEY et al., 1998 a, 1998b; REVANKAR et al., 1998; MARR et al., 1999).

Nos últimos anos, entretanto, um grande número de "kits" comerciais tem sido introduzidos como alternativas rápidas e de fácil utilização, principalmente em emergências médicas (PFALLER et al., 1998, ESPINEL-INGROFF et al., 1999, MARTIN-MAZUELOS et al., 1999). 
O "Etest" (AB Biodisk, Solna, Suécia) é um sistema comercial para testar a susceptibilidade antifúngica, baseado na difusão em meio sólido de diferentes concentrações de uma droga incorporada em tiras plásticas, e que permite a definição mais rapidamente da CIM da droga, tanto para bactérias como para fungos leveduriformes. Este método atualmente vem sendo muito utilizado pelos laboratórios, mostrando-se como uma prova mais rápida e de fácil realização em relação aos outros métodos já existentes (COLOMBO et al., 1995). Com a padronização da metodologia pode-se obter uma boa correlação com o método de referência (ESPINEL-INGROFF et al., 1996, PFALLER et al., 1996), embora menos de 50\% de concordância possa ocorrer para C. tropicalis e C. glabrata com relação ao fluconazol (SEWEL et al., 1994) e para cetoconazol e C. lusitaniae (FAVEL et al., 1999).

Avaliações preliminares do Etest sugerem uma similaridade de resultados com o método referência do CLSI (ESPINEL-INGROFF et al., 1996, POSTERARO et al., 2000; SILVA et al., 2002), sendo portanto, um método promissor para a execução dos testes de sensibilidade (COLOMBO et al., 1995).

Recentes avanços na biologia molecular têm permitido, através da análise do DNA genômico, o desenvolvimento de métodos moleculares para o estabelecimento de variações genéticas entre as amostras de leveduras, sendo estes métodos muito utilizados em investigações epidemiológicas, esclarecendo surtos hospitalares (PFALLER, 1995). A incorporação de métodos moleculares para a tipagem de patógenos nosocomiais têm contribuído nos esforços para estimar-se melhor a inter-relação entre as cepas. Estabelecer a clonalidade entre patógenos pode auxiliar na identificação da fonte (ambiental ou pessoal) do organismo, na distinção de cepas infecciosas de não infecciosas, na difrenciação entre uma recidiva e re-infecção, bem como no monitoramento da biodiversidade da população microbiana (CLEMONS et al, 1997; SINGH et al., 2006).

Vários métodos de tipagem molecular têm sido utilizados para diferenciar entre isolados de leveduras, uma vez que não existe um "gold standart". Entre eles incluim-se o RFLP(“Restriction Fragment Lengh Polymorphisms") utilizando-se enzimas de restrição, Eco RI, Hinfl e MspI (POIKONEN et al., 2001); o RFLP seguido da utilização de sondas de hibridização (TYLOR et al., 2003); o PCR do genoma inteiro através da análise do 
DNA polimórfico amplificado randomicamente-RAPD (SAMARANAYAKE et al., 2003), ou análise do polimorfismo do tamanho dos fragmentos do DNA amplificadosAFLP (BALL et al., 2004); a cariotipagem por PFGE ("Pulsed-Field Gel Eletrophoresis); fragmentos de PFGE gerados por endonucleases de restrição tais como SfiI (KANELlOPOULOU et al., 2001), SmaI, NotI, BssHII (RIEDERER et al., 1998), e a repetição de "tandens" curtos (STRs) ou microsatélites (SAMPAIO et al., 2003).

Exite um número importante de atributos para um esquema de tipagem de sucesso: a metodologia deve ser padronizada, sensível, específica, objetiva, e sujeita a avaliações críticas. Todos os sistemas de tipagem podem ser caracterizados em termos de tipabilidade, reprodutibilidade, poder discriminatório, manuseio e interpretação simples, e custo (SOLL, 2000)

Por mais de duas décadas a técnica de eletroforese em gel pulsado (PFGE) tem sido amplamente utilizada em análises epidemiológicas e no estudo da variedade de espécies de Candida, mostrando excelente poder discriminatório e reprodutibilidade (CHEN et al., 2005). O PFGE é uma técnica de eletroforese em gel de agarose que permite a separação de moléculas grandes de DNA, incluindo os cromossomos. Os cromossomos de diferentes isolados variam no tamanho, e cada amostra é caracterizada por um cariótipo. No entanto, o PFGE mostra-se uma técnica que consome muito tempo e de custo elevado (BRANCHINI et al., 1995).

Recentemente, a repetição de tandens curtos (STRs) ou microssatélites, também têm assumido um papel importante como marcadores moleculares de genomas eucariotos em diversas áreas, como na oncogenética, genética de populações e na caracterização e identificação de isolados (SAMPAIO et al., 2003). Estes ocorrem em milhares de cópias dispersas em todo o genoma, são geralmente constituídos por 1-6 nucleotídeos e exibem alto polimorfismo, transmissão codominante Mendeliana e tipagem por PCR (BOTTEREL et al., 2001). Alguns poucos lócus de microsatélites polimórficos tem sido identificados em relação ao genona de C. albicans, estando a maioria deles localizados próximos ou no interior de regiões codificadas e, exibindo um poder discriminatório entre 0.77 e 0.91 (LUNEL et al., 1998; METZGAR et al., 1998).

Os microssatélites são considerados marcadores estáveis, de fácil análise, adaptável à séries de ampla escala e com grande poder discriminatório, sendo utilizado 
como sistema de tipagem para investigar problemas clínicos, tais como a transmissão nosocomial de C. albicans (BOTTEREL et al., 2001).

Recentemente, alguns autores vêm utilizando os microssatélites como marcadores para diferenciar entre isolados de $C$. albicans e $C$. parapsilosis (DALLE et al., 2000; FUNDYGA et al., 2002; LOTT et a., 2003; LASKER et al., 2006).

Embora existam muitas técnicas disponíveis para a análise de amostras de uma população, ainda não há um método ideal. A escolha da técnica depende dos objetivos do estudo. 
OBJETIVOS 


\section{OBJETIVOS}

Com base nas considerações descritas quanto à importância das infecções fúngicas nosocomiais, principalmente por espécies de Candida, nota-se ainda inúmeras deficiências na habilidade de prevenção, diagnóstico precoce e correto bem como no tratamento das infecções por elas causados.

$\mathrm{Na}$ atualidade, infecções hospitalares por leveduras ocupam $3^{\circ} / 4^{\circ}$ lugar em várias Instituições Brasileiras, preocupando seriamente Órgãos Oficiais como a ANVISA.

Questões muito importantes relativas aos agentes etiológicos precisam ser melhor estudadas tais como a relação entre as cepas de episódios repetidos, patogenicidade das mesmas e, principalmente suscetibilidade às drogas antimicóticas e variações genotípicas.

Este trabalho teve como objetivos:

* Re-identificar os isolados de micoteca por método tradicional e "kit" comercial (API 20C), correlacionando-os para observar o nível de concordância;

Identificar, por métodos fenotípicos e moleculares (PCR), a possível presença de C. dubliniensis dentre as amostras de sangue identificadas inicialmente como $C$. albicans;

Determinar e comparar as concentrações inibitórias mínimas (CIMs) das amostras de leveduras isoladas de sangue, frente aos derivados azólicos: cetoconazol, fluconazol, itraconazol e voriconazol; frente a 5-fluorcitosina e caspofungina, e ao derivado poliênico anfotericina-B por meio da técnica de difusão em ágar ("Etest") utilizando-se meio RPMI + MOPS;

Verificar a diversidade genética dos isolados de leveduras do mesmo paciente (amostras sequenciais) por meio da técnica de cariotipagem (PFGE).

Estudar e comparar o perfil genotípico de isolados de $C$. albicans e $C$. parapsilosis de sangue, por meio da análise de marcadores microssatélites e cariotipagem (PFGE). 


\section{MATERIAL E MÉTODOS}




\section{MATERIAL E MÉTODOS}

Foram estudadas 70 amostras de leveduras isoladas de sangue no Hospital das Clínicas da Faculdade de Medicina de Botucatu-SP. A coleção de amostras inclui $31 C$. parapsilosis, 17 C. albicans, 10 C. tropicalis, 08 C. guilliermondii, 03 C. Krusei e uma C. glabrata. Estas amostras foram isoladas de pacientes internados neste hospital e fazem parte da Micoteca do Laboratório de Leveduras do ICBII da USP-São Paulo e do Laboratório de Micologia do IB da UNESP-Botucatu,SP. As amostras estão mantidas sob liofilização (freezer $-80^{\circ} \mathrm{C}$ ) e em óleo mineral.

\subsection{Re-caracterização das Amostras de Leveduras}

Método Tradicional: As leveduras isoladas foram re-estudadas quanto às suas características macroscópicas, microscópicas, reprodutivas e fisiológica, de acordo com os métodos preconizados por Kurtzman e Fell (1998) procedendo-se de modo geral, segundo protocolo (Anexo 01), utilizado para identificação de leveduras da Seção de Micologia do Departamento de Microbiologia do Instituto de Ciências Biomédicas USP, SP.

Método Comercial: A re-identificação dos isolados foi estudada pela reação de assimilação de açúcares através do "kit" comercial API 20C (bioMérieux Vitek, Inc., Hazelwood, Mo.). O procedimento foi realizado segundo instruções do fabricante.

\subsection{Técnica para Diferenciação entre $C$. albicans e $C$. dubliniensis}

\subsubsection{Fenotipagem}

As amostras de C. albicans foram cultivadas em ágar Sabouraud dextrose (DifcoDetroit, EUA) por 24 horas. Após incubação os isolados foram submetidos a: semeadura em meio CHROMagar Candida (CHROMagar, Microbiology, EUA) e incubação a $30^{\circ} \mathrm{C}$ por até cinco dias; e semeadura em ágar Sabouraud dextrose para testar sua capacidade de crescer a uma temperatura de $42^{\circ} \mathrm{C}$, segundo técnica descrita por Sullivan et al. (1995). 
A presença, na placa de CHROMagar, de colônias verde clara e o crescimento no ágar Sabouraud dextrose à $42^{\circ} \mathrm{C}$, indicaram que a amostra tratava-se de C. albicans. A presença de colônias verde escura e ausência de crescimento à $42^{\circ} \mathrm{C}$ são características típicas de C. dubliniensis.

Para estes testes forma utilizadas as cepas padrões: ATCC64548 (C. albicans) e 777 (C. dubliniensis).

\subsubsection{Genotipagem - Técnica de PCR}

\subsubsection{Extração do DNA (SCHERER e STEVENS, 1987)}

Amostras de C. albicans foram cultivadas em YPD ("Yeast Peptone Dextrose" Difco, Detroit, EUA) líquido, por 18 horas, a $37^{\circ} \mathrm{C}$, em tubos de ensaios estéreis, após o qual cada amostra foi recolhida e transferida para um tubo Eppendorf de 1,5 mL junto com 1,0 mL de tampão SET (Tris 20mM, EDTA 25mM, NaCl 75 mM, pH 8) para serem lavadas. Foram então adicionados $300 \mu \mathrm{L}$ de lisozima (Amersham-Pharmacia, EUA) em uma concentração de $3,0 \mathrm{mg} / \mathrm{mL}$ em tampão $\mathrm{SET}$, e os tubos foram incubados a $37^{\circ} \mathrm{C}$ durante sessenta minutos. À seguir, cerca de $25 \mu \mathrm{L}$ de RNase a 10,0 mg/mL (AmershamPharmacia, EUA) foi adicionada e a mistura foi incubada a $37^{\circ} \mathrm{C}$ por trinta minutos. Foram acrescentados então $50 \mu \mathrm{L}$ de SDS (Sodium dodecyl sulphate - Sigma, St. Louis, EUA) a $10 \%$ e $10 \mu \mathrm{L}$ de proteinase $\mathrm{K}$ a $10,0 \mathrm{mg} / \mathrm{mL}$ (Invitrogen, Brasil). A mistura foi incubada a $37^{\circ} \mathrm{C}$ por uma hora, após o qual cerca de $150 \mu \mathrm{L}$ de acetato de sódio (Merck, Germany) $3 \mathrm{M}$ foram acrescentados e a mistura foi mantida em banho de gelo durante dez minutos. Cerca de $500 \mu \mathrm{L}$ de uma mistura de fenol/clorofórmio/álcool isoamílico na proporção de 25:24:1 (Amersham-Pharmacia, EUA) foi adicionada, misturadas por inversão cerca de cinqüenta vezes e centrifugadas a $3.000 \mathrm{X}$ g por trinta minutos à temperatura ambiente. $\mathrm{O}$ sobrenadante foi transferido para outro tubo Eppendorf de 1,5 $\mathrm{mL}$. Foi então acrescentado $500 \mu \mathrm{L}$ de uma mistura de clorofórmio/álcool isoamílico (24:1), misturados por inversão cerca de cinqüenta vezes e centrifugados a $3.000 \mathrm{X}$ g por 15 minutos à temperatura ambiente. $\mathrm{O}$ sobrenadante foi transferido para outro tubo Eppendorf de 1,5 mL juntamente com igual volume de álcool isopropílico (AmershamPharmacia). O tubo foi invertido três ou quatro vezes e deixado por duas a três horas a - 
$20^{\circ} \mathrm{C}$. Os tubos foram então centrifugados durante trinta minutos a $3.000 \mathrm{X} \mathrm{g}$ e o sobrenadante foi descartado. Foi acrescentado etanol (Merck, Germany) a 70\%, e os tubos foram centrifugados a $3.000 \mathrm{X} \mathrm{g}$ durante 15 minutos. $\mathrm{O}$ sobrenadante foi descartado e o tubo foi secado a temperatura ambiente. O DNA presente no sedimento foi então ressuspendido em $25 \mu \mathrm{L}$ de tampão TE $1 \mathrm{X}$ (Tris 0,01M, EDTA $1 \mathrm{mM}, \mathrm{Ph} 7,5$ ). A quantificação do DNA extraído foi realizada por dosagem espectrofotométrica a $260 \mathrm{~nm}$ (Beckman DU640, EUA).

\subsubsection{Visualização do DNA extraído}

Géis de agarose a 0,8\% foram preparados em tampão TBE 1X (Tris 0,09M, ácido bórico 0,09M, EDTA 2mM, pH 8) que foi depositado em placa de acrílico apropriada, onde estava posicionado um pente de acrílico contendo oito espaçadores (Bio-Rad, EUA). Este foi coberto com tampão de corrida (TBE 1X) em cuba de eletroforese horizontal (Bio-Rad, EUA). Em cada poço do gel foi colocado cerca de $5 \mu \mathrm{L}$ de DNA e corante azul de bromofenol (V/V) (Invitrogen, Brasil), sendo que no primeiro poço foi aplicado marcador de peso molecular na seguinte proporção: $1 \mu \mathrm{L}$ do fago $\lambda$ digerido com HindIII (Amersham-Pharmacia), e $5 \mu \mathrm{L}$ de corante e $4 \mu \mathrm{L}$ de TE. A corrida foi realizada a $90 \mathrm{~V}$ por trinta minutos, até que o corante de corrida atingisse a extremidade oposta do gel. À seguir, o gel foi corado com brometo de etídio (Sigma, St. Louis, EUA) $2 \mu \mathrm{g} / \mathrm{mL}$ durante 15 minutos. A visualização da banda de DNA foi realizada com auxílio do equipamento GEL DOC 1000 sob iluminação de luz ultravioleta, com o programa "Molecular Analyst ${ }^{\mathrm{TM}}$ " (versão 1.4.1, Bio-Rad).

\subsubsection{Reação de PCR}

Foram utilizados dois pares de primers: um de C. dubliniensis e um de C. albicans (MANNARELLI et al., 1998). 
C. dubliniensis:

Sense: CDU2 5' AGT TAC TCT TTC GGG GGT GGC CT 3'

Anti-sense:NL4CAL 5'AAG ATC ATT ATG CCA ACA TCC TAG GTA AA 3'

C. albicans:

Sense: CAL5 5'TGT TGC TCT CTC GGG GGC GGC CG 3'

Anti-sense: NL4CAL 5'AAG ATC ATT ATG CCA ACA TCC TAG GTA AA 3'

Para o preparo do Mix de $25 \mu \mathrm{L}$ foram colocados em tubo Eppendorf, tampão com $2 \mathrm{mM}$ de $\mathrm{MgCl}_{2}$ (Biotools, Brasil), 0,2mM de dNTP (Biotools, Brasil), 0,5mM de cada primer (Invitrogen, Brasil), 1,2U de Taq Polimerase (Biotools, Brasil), $10 \mathrm{ng}$ de DNA da amostra e $\mathrm{H}_{2} \mathrm{O}$ miliq para completar o volume.

A amplificação foi realizada em termociclador (MJ Bio Research, EUA) com o seguinte programa: denaturação inicial de 3 minutos a $98{ }^{\circ} \mathrm{C}$ e 35 ciclos de 1 minuto a $95^{\circ} \mathrm{C}$ (denaturação), 1,5 minutos a $52{ }^{\circ} \mathrm{C}$ (anelamento), 1,5 minutos a $72{ }^{\circ} \mathrm{C}$ (extensão) e uma extensão final de 10 minutos a $72^{\circ} \mathrm{C}$. A presença de fragmento amplificado ou não foi analisada por eletroforese em gel de agarose a 1,2\%. Todas as análises incluíram um marcador de peso molecular de 100pb (Invitrogen, Brasil). Após a eletroforese, o gel foi corado com brometo de etídio (Sigma, St. Louis, EUA) $2 \mu \mathrm{g} / \mathrm{mL}$ e a vizualização dos fragmentos de DNA foi realizada com auxílio do equipamento GEL DOC 1000 sob

iluminação de luz ultravioleta, com o programa "Molecular Analyst" ${ }^{\mathrm{TM}}$ " (versão 1.4.1, Bio-Rad).

Para estes testes forma utilizadas as cepas padrões: ATCC64548 (C. albicans) e 777 (C. dubliniensis).

\subsection{Teste de Sensibilidade aos Antifúngicos}

3.3.1 Determinação da Concentração Inibitória Mínima (CIM) dos antifúngicos "kit" "Etest" (AB Biodisk, Solna, Suécia) 
Todas as leveduras isoladas do sangue foram estudadas frente a sete antifúngicos, para o estabelecimento da concentração inibitória mínima (CIM). Para isto utilizamos o "Etest" (AB Biodisk, Solna, Suécia), um teste comercial de sensibilidade a antifúngicos.

As fitas de "Etest" produzidas pela AB BIODISK (Solna, Suécia) são fitas plásticas com um gradiente definido e contínuo de antifúngico. Cada fita contém um gradiente de concentração correspondente a 0,016 a $256 \mu \mathrm{g} / \mathrm{mL}$ para fluconazol e 0,002 a $32 \mu \mathrm{g} / \mathrm{mL}$ para 5-fluorcitosina, cetoconazol, itraconazol, voriconazol e anfotericina B. As fitas de "Etest" foram armazenadas em freezer $-20^{\circ} \mathrm{C}$ até serem utilizadas. Todos os testes foram realizados empregando-se como cepas controle de qualidade Candida parapsilosis (ATCC 22019) e Candida krusei (ATCC 6258).

As leveduras foram previamente cultivadas em ágar Sabouraud-dextrose (Difco, Detroit, EUA) por 24 horas a $37^{\circ} \mathrm{C}$ e , a partir desses repiques foram feitas suspensões em salina estéril de acordo com a escala 0,5 de McFarland. O inóculo foi espalhado com auxílio de "swab" alginatado sobre a superfície do ágar contido em placas de Petri. O meio de cultura utilizado foi RPMI com $2 \%$ de glicose + MOPS, conforme recomendado pelo fabricante. As fitas foram colocadas cuidadosamente no centro da placa, sobre a superfície do ágar.

As placas foram então incubadas a $37^{\circ} \mathrm{C}$ durante 24 horas. A concentração inibitória mínima (CIM) foi considerada como a concentração que estava no ponto em que o limite da área de inibição do crescimento da levedura interceptava a fita de "Etest" (Figura 01). 


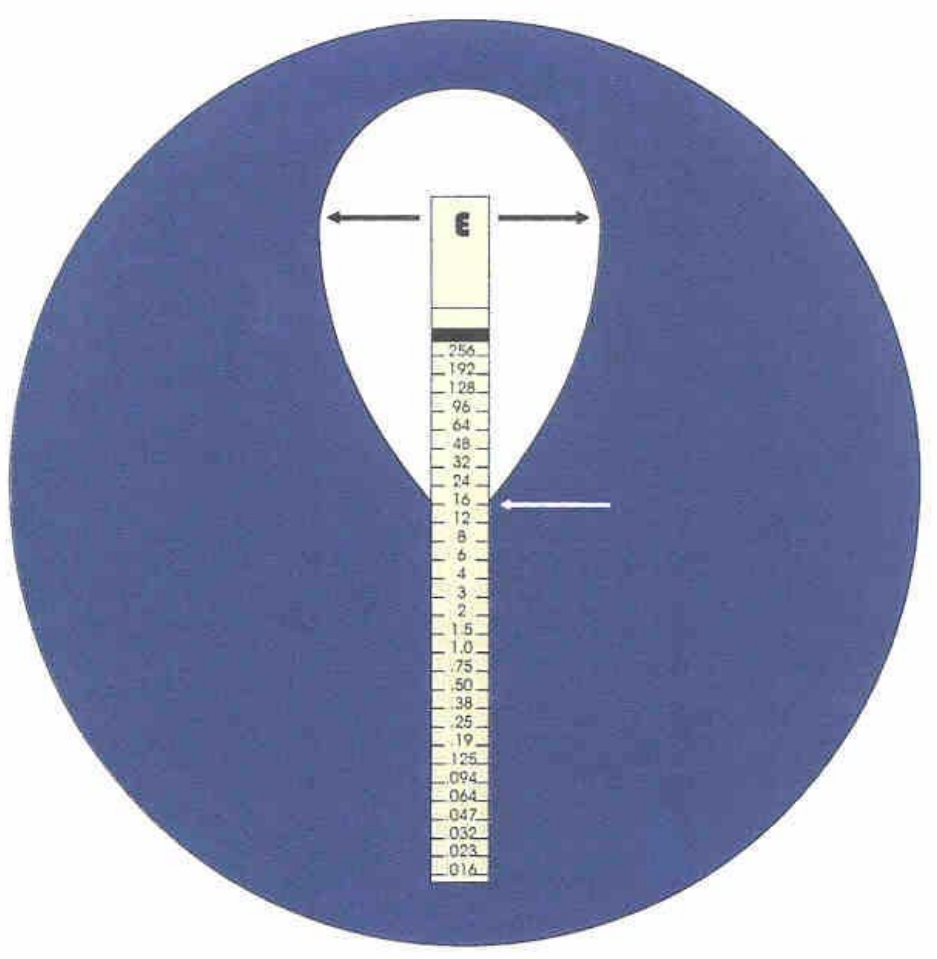

FIGURA 1 - Esquema metodológico da fita de "Etest" (antifúngicos $=\mu \mathrm{g} / \mathrm{mL}$ )

\section{Interpretação dos resultados}

O critério que seguimos para avaliar a sensibilidade antifúngica foi aquele recomendado pelo CLSI (M27A2-2002), que preconiza, de acordo com a Tabela 1, os seguintes valores de concentrações de drogas para avaliar a sensibilidade ou resistência aos antifúngicos. 
TABELA 1 - Interpretação do comportamento de cepas de Candida sp, segundo normas do CLSI (M27A2-2002), frente a concentração dos antifúngicos $\mu \mathrm{g} / \mathrm{mL}$.

\begin{tabular}{lcccc}
\hline \multicolumn{1}{c}{$\begin{array}{c}\text { Agentes } \\
\text { Antifúngicos }\end{array}$} & Sensíveis & $\begin{array}{c}\text { Sensível Dose } \\
\text { Dependente } \\
\text { (SDD) }\end{array}$ & Intermediário & Resistentes \\
\hline Fluconazol & $\leq 8$ & $16-32$ & - & $\geq 64$ \\
Itraconazol & $\leq 0,125$ & $0,25-0,5$ & - & $\geq 1$ \\
5-Fluorcitosina & $\leq 4$ & - & $8-16$ & $\geq 32$ \\
Anfotericina B & - & - & - & $>2$ (Sugere) \\
\hline
\end{tabular}

Esse critério acima não estipula valores para o cetoconazol que é considerada um droga fungistática. Apenas indica que a maioria dos valores são encontrados entre 0,03 e $16 \mu \mathrm{g} / \mathrm{mL}$ para os isolados clínicos (M27-A2) CLSI. Neste estudo valores acima de $16 \mu \mathrm{g} / \mathrm{mL}$ foram considerados como resistência.

Para voriconazol, cepas com CIMs acima de $1 \mu \mathrm{g} / \mathrm{mL}$ foram consideradas resistentes, segundo documento do CLSI-M27-S2 (2005). Para a caspofungina, as cepas foram consideradas resistentes quando mostravam CIMs maiores que $2 \mu \mathrm{g} / \mathrm{mL}$ (PFALLER et al., 2008).

\subsection{Perfis Genéticos das Amostras de Leveduras}

\subsubsection{Cariotipagem - Eletroforese em campo pulsátil (PFGE) (BRANCHINI et al., 1994 modificado)}

Foram estudadas 24 amostras sequenciais de Candida isoladas de nove pacientes diferentes para verificar a diversidade de perfis moleculares destas cepas.

Também empregou-se a técnica de PFGE para todas as amostras de C. albicans (17) e C. parapsilosis (29).

As amostras de Candida foram repicadas em ágar Sabouraud dextrose (Difco, Detroit, EUA) e incubadas a $35^{\circ} \mathrm{C}$ por 24 horas. As colônias que cresceram na superfície do ágar foram semeadas em placas de ágar YPD (Difco, Detroit, EUA), incubando-se a 
$35^{\circ} \mathrm{C}$. Cerca de 200 a $300 \mu \mathrm{L}$ de células foram transferidas em tubos de Eppendorf contendo a mesma quantidade de EDTA $(50 \mathrm{mM}, \mathrm{pH} 8,0)$ e agitado em vortex. Os tubos foram centrifugados a $3000 \mathrm{rpm}$ sob refrigeração a $4^{\circ} \mathrm{C}$ por 15 minutos. $\mathrm{O}$ sobrenadante foi desprezado e adicionou-se EDTA $(50 \mathrm{mM}, \mathrm{pH} 8,0)$ novamente para a lavagem das células. Esse procedimento foi repetido por mais duas vezes. Após a última lavagem foi adicionado $300 \mu \mathrm{L}$ de EDTA $(50 \mathrm{mM}, \mathrm{pH} 8,0)$ e homogeneizado. A esta suspensão de células foi adicionado $160 \mu \mathrm{L}$ da enzima Lyticase $(1250 \mathrm{U} / \mathrm{mL})$ dissolvida em glicerol $50 \%$ (vol/vol)-0,01 $\mathrm{M} \mathrm{NaPO}_{4}$, pH 7,5 (Sigma, St. Louis, EUA) e incubada a $37^{\circ} \mathrm{C}$ por 60 minutos. Após foi acrescentado a esta solução $400 \mu \mathrm{L}$ de agarose "low-melt"(Bio-Rad) a 0,8\% dissolvida em 50mM de EDTA, $\mathrm{pH} 8,0$, e mantida liquefeita a $50^{\circ} \mathrm{C}$. A mistura foi homogeneizada suavemente e colocada rapidamente em moldes. $\mathrm{O}$ conjunto foi mantido sob refrigeração a $4^{\circ} \mathrm{C}$ por um período de 20 minutos. Em seguida os blocos foram removidos dos moldes e colocados em tubos de fundo chato contendo $3 \mathrm{~mL}$ de tampão

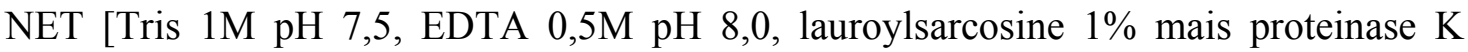
$\left(1 \mathrm{mg} / \mathrm{mL} ; 20 \mathrm{U} / \mathrm{mg}\right.$ Invitrogen, Brasil)] . Esses tubos foram incubados a $50^{\circ} \mathrm{C}$ por 18 horas. Os blocos foram, então, lavados três vezes com $2 \mathrm{~mL}$ de EDTA $(50 \mathrm{mM}$ pH 8,0) por 30 minutos sob agitação a temperatura ambiente. Uma quarta lavagem foi feita e os tubos foram mantidos a temperatura ambiente, sob agitação, por 24 horas. Após este período foram realizadas mais duas lavagens e os blocos estavam prontos para a corrida eletroforética.

Para separação do DNA cromossômico de diferentes pesos moleculares, foi utilizado o aparelho CHEF MAPPER (Bio-Rad). Para tal os blocos de agarose das amostras e do peso molecular foram cortados na largura dos dentes do pente e fixados com a própria agarose de corrida. O pente foi posicionado no molde para o gel do sistema CHEF MAPPER (Bio-Rad) e então adicionado agarose 1\% (Sigma, Detroit, EUA) liquefeita. Após solidificação, o pente foi retirado e os poços contendo os blocos foram preenchidos com agarose (Sigma, Detroit, EUA). Para a realização da corrida, 2,5 litros de tampão TBE $0,5 x$ foram colocados na cuba do aparelho e a temperatura ajustada para $14^{\circ} \mathrm{C}$. As condições de corrida foram: Bloco 1 com tempo de corrida de 23 horas sob voltagem de $5 \mathrm{~V} / \mathrm{cm}$ e tempo de pulso inicial e final de 120 segundos. ; bloco 2 com 
tempo de corrida de 11 horas sob voltagem de $5 \mathrm{~V} / \mathrm{cm}$ e tempo de pulso inicial e final de 240 segundos.

O gel foi corado com brometo de etídio durante 15 minutos e descorado em água destilada por cerca de 60 minutos. A visualização foi realizada com o auxílio do equipamento GEL DOC 1000 sob iluminação ultravioleta, com o programa "Molecular Analyst $^{\mathrm{TM}}$ ", (versão 1.4.1, Bio-Rad).

A diferenciação entre os isolados foi obtida pela comparação visual dos cariótipos eletroforéticos (BARCHESI et al., 1995). Isolados foram considerados como possuindo o mesmo perfil quando a banda que estava presente em uma amostra também estava presente na outra. Não foi levado em consideração a intensidade das bandas.

\subsubsection{Técnica de Microssatélites}

Esta técnica foi empregada para todas as amostras de $C$. albicans (17) e $C$. parapsilosis (29).

\subsubsection{Extração do DNA (SCHERER e STEVENS, 1987)}

Amostras de C. albicans foram cultivadas em YPD ('Yeast Peptone Dextrose' Difco, Detroit, EUA) líquido por 18 horas $37^{\circ} \mathrm{C}$, em tubos de ensaios estéreis, após o qual cada amostra foi recolhida e transferida para um tubo Eppendorf de 1,5 mL junto com 1,0 mL de tampão SET (Tris 20mM, EDTA 25mM, NaCl 75 mM, pH 8) para serem lavadas. Foram então adicionados $300 \mu \mathrm{L}$ de lisozima (Amersham-Pharmacia) em uma concentração de $3,0 \mathrm{mg} / \mathrm{mL}$ em tampão $\mathrm{SET}$, e os tubos foram incubados a $37^{\circ} \mathrm{C}$ durante sessenta minutos. A seguir, cerca de $25 \mu \mathrm{L}$ de RNase a 10,0 mg/mL (AmershamPharmacia) foi adicionada e a mistura foi incubada a $37^{\circ} \mathrm{C}$ por trinta minutos. Foram acrescentados então $50 \mu \mathrm{L}$ de SDS (Sodium dodecyl sulphate - Sigma, St. Louis, EUA) a $10 \%$ e $10 \mu \mathrm{L}$ de proteinase $\mathrm{K}$ a 10,0 mg/mL (Invitrogen, Brasil). A mistura foi incubada a $37^{\circ} \mathrm{C}$ por uma hora, após o qual cerca de $150 \mu \mathrm{L}$ de acetato de sódio (Merck, Germany) $3 \mathrm{M}$ foram acrescentados e a mistura foi mantida em banho de gelo durante dez minutos. Cerca de $500 \mu \mathrm{L}$ de uma mistura de fenol/clorofórmio/álcool isoamílico na proporção de 
25:24:1 (Amersham-Pharmacia) foi adicionada, misturadas por inversão cerca de cinqüenta vezes e centrifugadas a $3.000 \mathrm{Xg}$ por trinta minutos à temperatura ambiente. $\mathrm{O}$ sobrenadante foi transferido para outro tubo Eppendorf de $1,5 \mathrm{~mL}$. Foi então acrescentado $500 \mu \mathrm{L}$ de uma mistura de clorofórmio/álcool isoamílico (24:1), misturados por inversão cerca de cinqüenta vezes e centrifugados a $3.000 \mathrm{X}$ g por 15 minutos à temperatura ambiente. $\mathrm{O}$ sobrenadante foi transferido para outro tubo Eppendorf de 1,5 $\mathrm{mL}$ juntamente com igual volume de álcool isopropílico (Amersham-Pharmacia). O tubo foi invertido três ou quatro vezes e deixado por duas a três horas a $-20^{\circ} \mathrm{C}$. Os tubos foram então centrifugados durante trinta minutos a $3.000 \mathrm{X}$ g e o sobrenadante foi descartado. Foi acrescentado etanol (Merck, Germany) a 70\%, e os tubos foram centrifugados a 3.000 $\mathrm{X}$ g durante 15 minutos. O sobrenadante foi descartado e o tubo foi secado a temperatura ambiente. O DNA presente no sedimento foi então ressuspendido em $25 \mu \mathrm{L}$ de tampão TE 1X (Tris 0,01M, EDTA 1mM, Ph 7,5). A quantificação do DNA extraído foi realizada por dosagem espectrofotométrica a $260 \mathrm{~nm}$ (Beckman DU640, EUA).

\subsubsection{Visualização do DNA extraído}

Géis de agarose a 0,8\% foram preparados em tampão TBE $1 \mathrm{X}$ (Tris $0,09 \mathrm{M}$, ácido bórico 0,09M, EDTA 2mM, pH 8) que foi depositado em placa de acrílico apropriada, onde estava posicionado um pente de acrílico contendo oito espaçadores (Bio-Rad, EUA). Este foi coberto com tampão de corrida (TBE 1X) em cuba de eletroforese horizontal (Bio-Rad, EUA). Em cada poço do gel foi colocado cerca de $5 \mu \mathrm{L}$ de DNA e corante azul de bromofenol (V/V) (Invitrogen, Brasil), sendo que no primeiro poço foi aplicado marcador de peso molecular na seguinte proporção: $1 \mu \mathrm{L}$ do fago $\lambda$ digerido com HindIII (Amersham-Pharmacia), e $5 \mu \mathrm{L}$ de corante e $4 \mu \mathrm{L}$ de TE. A corrida foi realizada a $90 \mathrm{~V}$ por trinta minutos, até que o corante de corrida atingisse a extremidade oposta do gel. A seguir, o gel foi corado com brometo de etídio (Sigma, St. Louis, EUA) $2 \mu \mathrm{g} / \mathrm{mL}$ durante 15 minutos. A visualização da banda de DNA foi realizada com auxílio do equipamento GEL DOC 1000 sob iluminação de luz ultravioleta, com o programa "Molecular Analyst ${ }^{\mathrm{TM}}$ " (versão 1.4.1, Bio-Rad). 


\subsubsection{Análise dos Microssatélites}

Foram analisados, nas amostras de C. albicans, os locus microssatélites $C E F 3\left(1^{\circ}\right.$ “primer”)(“translation elongation-fator gene”), (BRETAGNE et al., 1997) que localiza-se no cromossoma 5; o ERK1 (2 " "primer") ("gene regulador do sinal extracelular de kinase”), (METZGAR et al., 1998) que localiza-se no cromossomo 4; o CDC3 (3 “primer")(“cell division cycle protein gene”), (DIDOMENICO et al., 1994) que localizase no cromossoma 1; o EF3 (4 “primer") (“elongation factor 3 gene”), (MYERS et al., 1992) que localiza-se no cromossoma 5; e o HIS3 (5 "primer") ("imidazole glycerol phosphate deshydratase gene"), (MAGEE et al., 1998). As seqüência repetitivas de nucleotídeos desses microsatélites e os primers utilizados para reação de PCR (Tabela 2), estão baseados em publicação prévia (BOTTEREL et al., 2001; FUNDYGA et al., 2002). 
TABELA 2 - Locus microssatélites para caracterização de C. albicans, primers e descrição.

\begin{tabular}{|c|c|c|}
\hline Lócus & "Primers" & "Tandens" repetitivos \\
\hline \multirow[t]{2}{*}{ CEF3 } & Sense: TTTCCTCTTCCTTTCATATAGAA & \\
\hline & Anti-sense:GGATTCACTAGCAGCAGACA & TTC/TTTC \\
\hline \multirow[t]{2}{*}{ ERK1 } & Sense: CGACCACGTCATCAATACAAATCG & $(\mathrm{CAGGCT})_{\mathrm{a}}(\mathrm{CAAGCT})_{\mathrm{b}}$ \\
\hline & Anti-sense: CGTTGAATGAAACTTGACGAGGGG & $\ldots(\mathrm{CAA})_{\mathrm{c}} \ldots(\mathrm{GCCGCA})_{\mathrm{d} \ldots} .(\mathrm{CTT})_{\mathrm{e}}$ \\
\hline \multirow[t]{2}{*}{$C D C 3$} & Sense: CAGATGATTTTTTGTATGAGAAGAA & $(\mathrm{AGTA})_{8}$ \\
\hline & Anti-sense:CGATCACAAGATTAAAATGTTCAAG & \\
\hline \multirow[t]{2}{*}{$E F 3$} & Sense: TTTCCTCTTCCTTTCATATAGAA & $(\mathrm{TTTC})_{5}(\mathrm{TTC})_{5}$ \\
\hline & Anti-sense: GGATTCACTAGCAGCAGACA & \\
\hline \multirow[t]{2}{*}{$H I S 3$} & Sense: TGGCAAAAATGATATTCCAA & $(\mathrm{ATTT})_{13}$ \\
\hline & Anti-sense: TACACTATGCCCCAAACACA & \\
\hline
\end{tabular}

Fonte: BOTTEREL et al. (2001); FUNDYGA et al. (2002).

Para as amostras de C. parapsilosis foram analisados os locus microsatélites $A, B$ e $D$. As seqüência repetitivas de nucleotídeos desses microsatélites e os primers utilizados para a reação de PCR (Tabela 3), estão baseados em publicação prévia (LASKER et al., 2006). 
TABELA 3 - Locus microssatélites para caracterização de C. parapsilosis, primers e descrição.

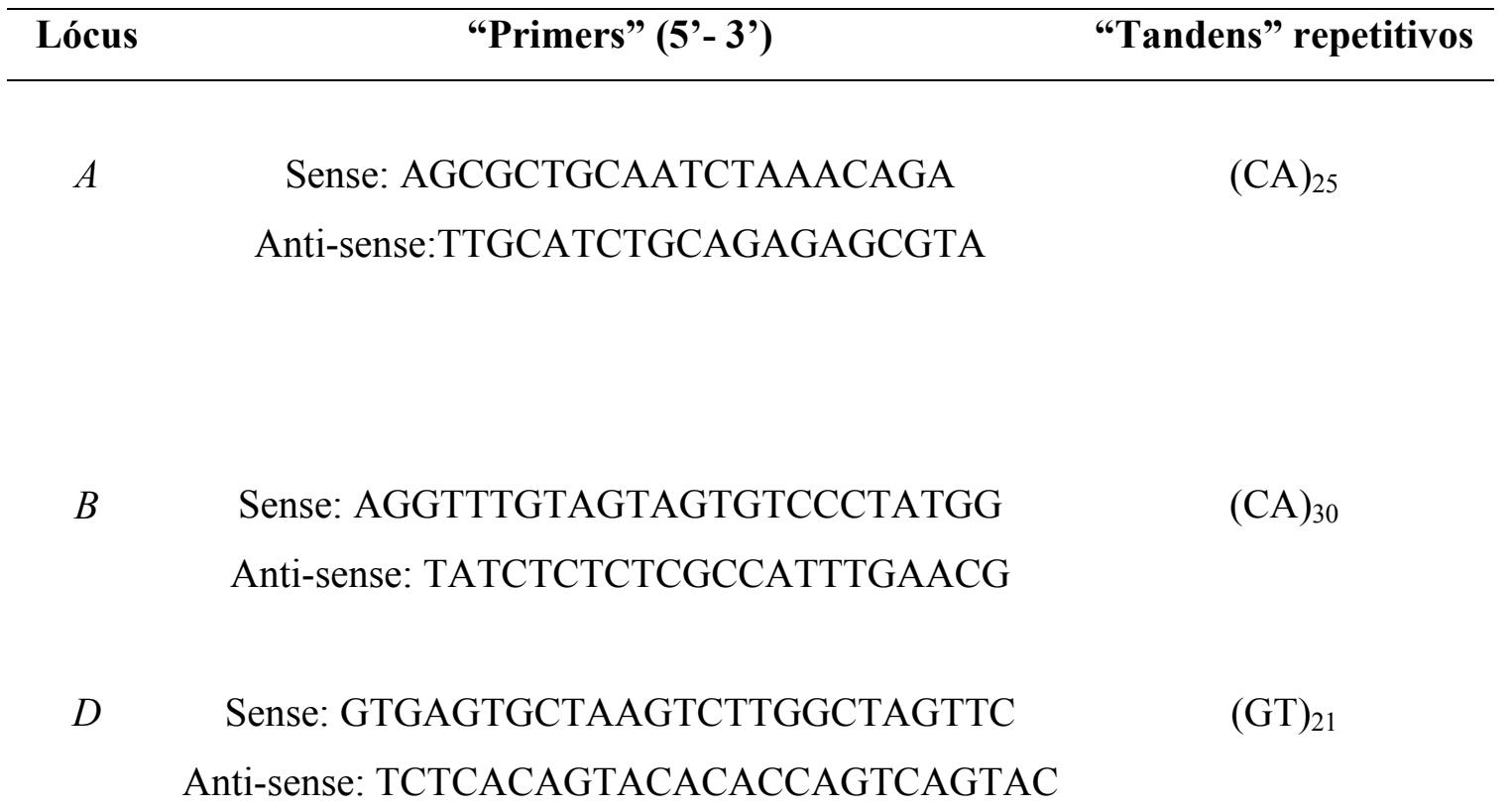

Fonte: LASKER et al. (2006)

Para garantir a reprodutibilidade do método, foi utilizado em cada experimento uma cepa padrão de C. albicans (ATCC64548) e de C. parapsilosis (ATCC220190).

Cada par de primer do PCR foi sintetizado e os primers anti-sense de cada par foi marcado com fluorescência: EKR1, EF3, A, B, e D com FAM; CEF3 e HIS3 com TET; CDC3 com HEX.

Os lócus para C. albicans foram, então, amplificados por PCR em reações de 25 $\mu l$ contendo tampão $\mathrm{Mg}^{+} 1 \mathrm{x}$ (Biotools, Brasil), $1 \mu \mathrm{M}$ de cada primer (Invitrogen, Brasil), 0,2 $\mu \mathrm{M}$ de dNTPs (Biotools, Brasil), $1 \mathrm{U}$ de Tap Polimerase (Biotools, Brasil) e $1 \mu \mathrm{l}$ de DNA extraído de cada amostra. A amplificação foi realizada nos seguintes parâmetros: desnaturação à $95^{\circ} \mathrm{C}$ por 5 minutos; 35 ciclos para desnaturação por 1 minuto a $95^{\circ} \mathrm{C}$, anelamento à $55^{\circ} \mathrm{C}$ por 1 minuto e extensão à $72^{\circ} \mathrm{C}$ por 1 minuto; e uma extensão final de $72^{\circ} \mathrm{C}$ por 5 minutos. O lócus $C E F 3$ requeriu uma temperatura de anelamento de $50^{\circ} \mathrm{C}$.

Para a amplificação dos lócus de C. parapsilosis, a PCR foi realizada em reações de $25 \mu$ l contendo tampão $\mathrm{Mg}^{+} 1 \mathrm{x}$ (Biotools, Brasil), 0,2 $\mu \mathrm{M}$ de cada primer (Invitrogen, 
Brasil), 0,2 $\mu \mathrm{M}$ de dNTPs (Biotools, Brasil), 2,5 U de Taq Polimerase (Biotools, Brasil) e $1 \mu \mathrm{L}$ de DNA extraído de cada amostra. Os parâmetros para a mplificação foram: desnaturação à $95^{\circ} \mathrm{C}$ por 3 minutos; 30 ciclos para desnaturação por 30 segundos a $95^{\circ} \mathrm{C}$, anelamento à $58^{\circ} \mathrm{C}$ por 30 segundos e extensão à $72^{\circ} \mathrm{C}$ por 1 minuto; e uma extensão final de $72^{\circ} \mathrm{C}$ por 5 minutos.

As reações de amplificação foram realizadas em aparelho Termociclador (MJ Research PTC-100).

\subsubsection{Leitura e interpretação dos dados}

$\mathrm{O}$ produto de PCR foi analisado em aparelho de sequenciador automático MegaBACE 1000 (Amersahm Biosciences-GE) por sistema de eletroforese de capilar, utilizando o software Genetic Profiler e fazendo uso do MegaBACE ET-550R, como marcador padrão, com fragmentos que variam de 60 a 550 pares de bases.

A diferenciação entre os isolados foi obtida pela comparação do comprimento de pares de bases obtido do produto de PCR de cada isolado, segundo Botterel et al. (2001).

\subsubsection{Comparação entre as Técnicas de Microssatélites e Cariotipagem aplicadas as amostras de $C$. albicans e $C$. parapsilosis}

Foram estudadas 17 amostras de C. albicans e 29 amostras de C.parapsilosis,em relação a diversidade genética. Foram utilizadas as técnicas de microssatélites e cariotipagem (PFGE), para posterior comparação em relação ao poder discrminatório entre ambas as técnicas.

\subsubsection{Análise Estatística}

Verificamos o poder discriminatório (D) das técnicas de microssatélites e cariotipagem para diversidade genética das 17 amostras de C. albicans e 31 amostras de C. parapsilosis, por meio da fórmula preconizada por Hunter e Gaston (1988): 


$$
\begin{array}{ll}
\mathrm{D}=1-\frac{1}{N(N-1)} & \sum^{\mathrm{s}} n_{j-} n_{j}-1 \\
\mathrm{j}=1
\end{array}
$$

Onde:

$\mathrm{D}=$ Poder discriminatório ou Index discriminatório

$\mathrm{N}=$ número total de isolados

$\mathrm{S}=$ número total de perfi obtidos

$n j=$ número de amostras pertencentes a cada perfil 
RESULTADOS 


\section{RESULTADOS}

\subsection{Re-caracterização das Amostras de Leveduras}

O nível de concordância entre o método tradicional e o sistema API20C, na identificação das 70 espécies de Candida foi de 93\% (65/70).

O sistema API 20C identificou de modo diverso 03 isolados de C. tropicalis como C. guilliermondii, e 02 isolados de C. krusei como Saccharomyces sp (Tabela 04).

TABELA 4 - Identificação de 70 leveduras do gênero Candida pelo método tradicional e sistema API 20C.

\begin{tabular}{lccc}
\hline \multicolumn{1}{c}{ Espécies } & $\begin{array}{c}\text { Identificação } \\
\text { método } \\
\text { tradicional }\end{array}$ & $\begin{array}{c}\text { Identificação } \\
\text { API 20C }\end{array}$ & $\begin{array}{c}\text { Não } \\
\text { identificado }\end{array}$ \\
\hline C. parapsilosis & 31 & 31 & 0 \\
C. albicans & 17 & 17 & 0 \\
C. tropicalis & 10 & 07 & 0 \\
C. guilliermondii & 08 & 11 & 0 \\
C. krusei & 03 & 01 & 0 \\
C. glabrata & 01 & 01 & 0 \\
Saccharomyces $\mathrm{sp}$ & 0 & 02 & 0 \\
\hline Total & $\mathbf{7 0}$ & $\mathbf{7 0}$ & $\mathbf{0}$ \\
\hline
\end{tabular}

\subsection{Diferenciação entre $C$. albicans e $C$. dubliniensis}

Um total de 17 amostras, inicialmente identificadas como C. albicans com base na caracterização fenotípica, foram consideradas para análise.

Dos 17 isolados semeados em ágar Sabouraud dextrose e incubados a temperatura de $42^{\circ} \mathrm{C}$, observamos que $100 \%$ apresentaram crescimento sob estas condições. 
Do total de amostras testadas no meio CHROMagar Candida, foi observado que 16 isolados $(94,1 \%)$ exibiram coloração verde claro enquanto uma amostra $(5,8 \%)$ exibiu coloração rosada.

A identificação genotípica foi realizada pelo método de PCR. O tamanho do fragmento amplificado pelos "primers" CAL5/NL4CAL e pelos "primers" CDU2/NA4CAL, de 175pb, corresponde àqueles observados por Mannarelli \& Kurtzman (1998), permitiu desta forma a identificação das espécies.

Observamos que $100 \%$ das amostras não apresentaram amplificação do fragmento quando utilizado o primer CDU/NL4CAL (C. dubliniensis), no entanto quando utilizado o primer CAL5/NL4CAL (C. albicans) os isolados apresentaram amplificação do fragmento, sendo, portanto, identificadas como C. albicans (Figura 02).

Com base nas características fenotípicas e genotípicas, podemos considerar que todas as 17 amostras inicialmente identificadas como C. albicans permanecem com esta classificação.

Apenas uma amostra demonstrou coloração outra que verde claro, mesmo exibindo crescimento a $42^{\circ} \mathrm{C}$ em meio Sabouraud dextrose e apresentando as demais características fenotípicas típicas da espécie, bem como amplificação do fragmento para identificação molecular de C. albicans. 


\section{A}

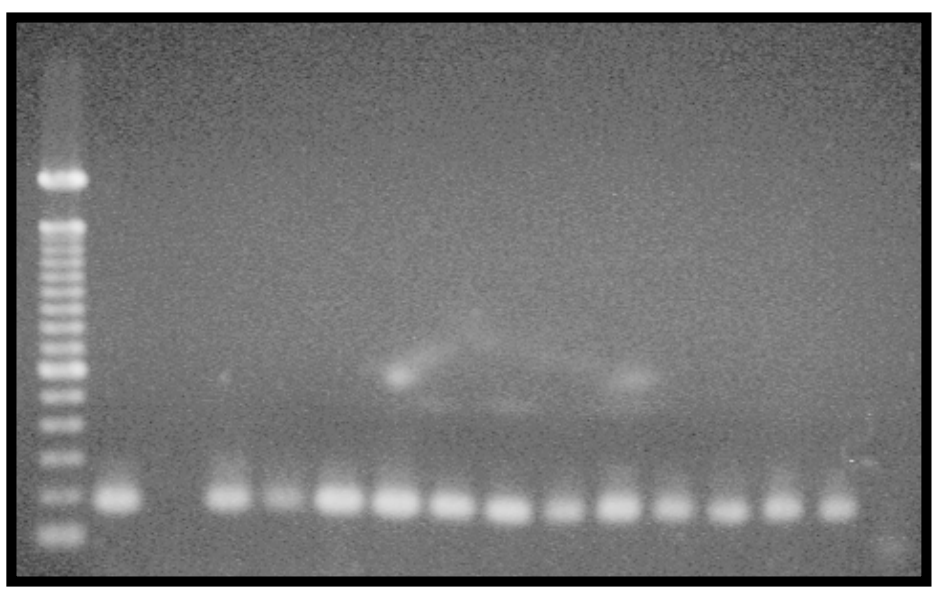

B

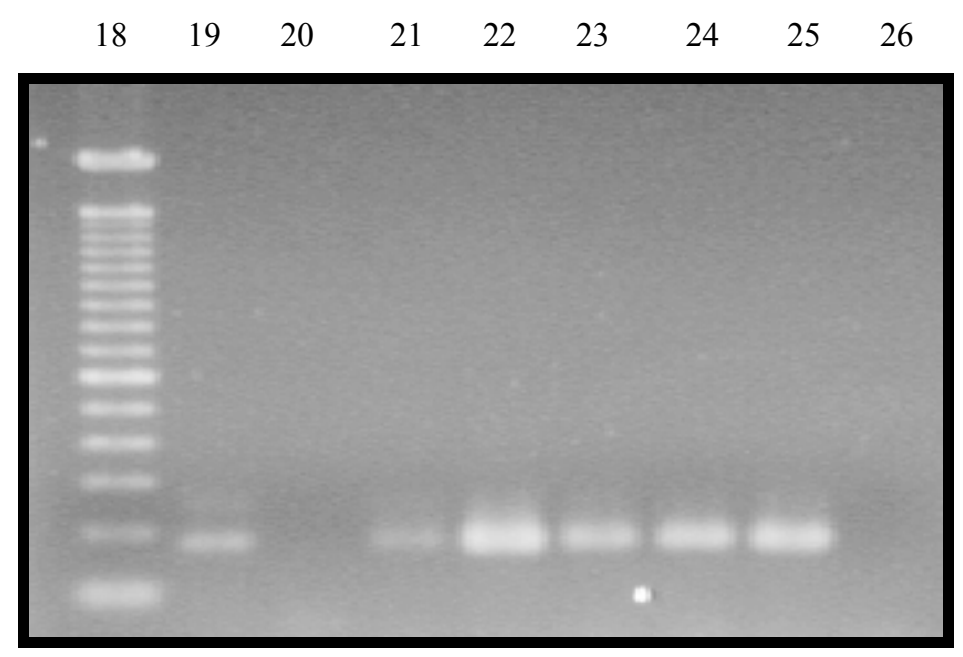

FIGURA 2 - Amplificação do fragmento de $175 \mathrm{pb}$ de 17 isolados de C. albicans, obtidos através da técnica de PCR utilizando-se primer CAL5/NL4CAL. Todas as amostras amplificaram o fragmento correspondente àquele de C. albicans. A - linha 1 padrão de peso molecular; linha 2 C. albicans ATCC 64548; linha 2 C. dubliniensis ATCC 777; linhas de 5 a 16 isolados em estudo; linha 17 controle negativo. B linha 18 padrão de peso molecular; linha 19 C. albicans ATCC 64548; linha 20 C. dubliniensis ATCC 777; linhas 21 - 25 isolados estudados; linha 26 controle negativo. 


\subsection{Sensibilidade Antifúngica}

Os dados de sensibilidade e resistência das amostras de Candida são mostrados na Tabela 5. Baseado nos resultados do método Etest, a Tabela 5 mostra o número de isolados para cada espécie classificada como sensível (S), sensível dose dependente (SDD) e resistente (R) de acordo com os "breakpoints" da CIM recomendado pelo documento M27-A2 (CLSI, 2002).

As amostras de C. parapsilosis, C. albicans, C. tropicalis e C. glabrata apresentaram alta porcentagem de amostras sensíveis (de 90,3 a 100\%) às sete drogas testadas. As amostras de C. guilliermondii apresentaram uma menor porcentagem de sensibilidade em relação ao fluconazol $(75 \%)$, 5-fluorcitosina $(87,5 \%)$ e itraconazol (25\%). C. krusei apresentou menor sensibilidade aos antifúngicos fluconazol e itraconazol, 66,6\% para ambos. C. tropicalis apresentou menor sensibilidade apenas para o itraconazol e caspofungina ( $80 \%$ e $96,7 \%$, respectivamente), enquanto para os demais antifúngicos esta espécie apresentou $100 \%$ de sensibilidade.

A Tabela 6 mostra os intervalos das CIMs e as CIMs 50\% e 90\% das amostras (CIM 50 e 90 respectivamente) obtidas das espécies de Candida. A maioria dos valores de CIM 50 e 90 apresentaram valores baixos considerados como sensíveis. Os maiores valores de CIM 90 foram apresentados pelas amostras de C. guilliermondii e C. krusei para os antifúngicos fluconazol e itraconazol.

Com relação a anfotericina $\mathrm{B}, 96,7 \%$ dos isolados mostraram-se sensíveis, sendo que um isolado de $C$. parapsilosis apresentou resistência a este antifúngico.

Em relação a caspofungina, notamos que as CIMs para as 70 amostras estudadas variaram de $0,032-2 \mu \mathrm{g} / \mathrm{mL}$, com isso, $100 \%$ dos isolados mostraram-se sensíveis a droga. 
TABELA 5 - Sensibilidade das espécies de Candida isoladas de sangue de pacientes internados no Hospital das Clinicas de Botucatu, São Paulo, frente aos antifúngicos estudados.

\begin{tabular}{|c|c|c|c|}
\hline \multirow[t]{2}{*}{ Espécies (n)/drogas antifúngicas } & \multicolumn{3}{|c|}{$\%$ de isolados } \\
\hline & $\mathbf{S}$ & SDD & $\mathbf{R}$ \\
\hline \multicolumn{4}{|l|}{ C. parapsilosis $(\mathrm{n}=31)$} \\
\hline Cetoconazol & 100 & - & - \\
\hline Fluconazol & 90,3 & 9,7 & - \\
\hline 5-Fluorcitosina & 100 & - & - \\
\hline Anfotericina B & 96,7 & - & 3,3 \\
\hline Itraconazol & 100 & - & - \\
\hline Voriconazol & 100 & - & - \\
\hline Caspofungina & 100 & - & - \\
\hline \multicolumn{4}{|l|}{ C. albicans $(\mathrm{n}=17)$} \\
\hline Cetoconazol & 100 & - & - \\
\hline Fluconazol & 100 & - & - \\
\hline 5-Fluorcitosina & 100 & - & - \\
\hline Anfotericina B & 100 & - & - \\
\hline Itraconazol & 100 & - & - \\
\hline Voriconazol & 100 & - & - \\
\hline Caspofungina & 100 & - & - \\
\hline \multicolumn{4}{|l|}{ C. tropicalis $(\mathrm{n}=10)$} \\
\hline Cetoconazol & 100 & - & - \\
\hline Fluconazol & 100 & - & - \\
\hline 5-Fluorcitosina & 100 & - & - \\
\hline Anfotericina B & 100 & - & - \\
\hline Itraconazol & 80 & 20 & - \\
\hline Voriconazol & 100 & - & - \\
\hline Caspofungina & 96,7 & - & 3,3 \\
\hline \multicolumn{4}{|l|}{ C. guilliermondii $(\mathrm{n}=08)$} \\
\hline Cetoconazol & 100 & - & - \\
\hline Fluconazol & 75 & 25 & - \\
\hline 5-Fluorcitosina & 87,5 & - & 12,5 \\
\hline Anfotericina B & 100 & - & - \\
\hline Itraconazol & 25 & 37,5 & 37,5 \\
\hline Voriconazol & 100 & - & - \\
\hline Caspofungina & 100 & - & - \\
\hline \multicolumn{4}{|l|}{ C. krusei $(\mathrm{n}=03)$} \\
\hline Cetoconazol & 100 & - & - \\
\hline Fluconazol & 66,6 & 33,4 & - \\
\hline 5-Fluorcitosina & 100 & - & - \\
\hline Anfotericina B & 100 & - & - \\
\hline Itraconazol & 66,6 & - & 33,4 \\
\hline Voriconazol & 100 & - & - \\
\hline
\end{tabular}


Tabela 5 (Continuação)

\begin{tabular}{cccc}
\hline Espécies (n)/drogas antifúngicas & \multicolumn{3}{c}{$\%$ de isolados } \\
\cline { 2 - 4 } & S & SDD & R \\
\hline C. glabrata (n=01) & & & - \\
Cetoconazol & 100 & - & - \\
Fluconazol & 100 & - & - \\
5-Fluorcitosina & 100 & - & - \\
Anfotericina B & 100 & - & - \\
Itraconazol & 100 & - & - \\
Voriconazol & 100 & - & - \\
Caspofungina & 100 & - & - \\
\hline
\end{tabular}


TABELA 6 - Sensibilidade in vitro de Candida isoladas de sangue frente a sete antifúngicos através do método comercial Etest (CIM $\mu \mathrm{g} / \mathrm{mL})$.

\begin{tabular}{|c|c|c|c|}
\hline \multirow[t]{2}{*}{ Espécies (n)/drogas antifúngicas } & \multicolumn{3}{|c|}{ CIM $(\mu \mathrm{g} / \mathrm{mL})$} \\
\hline & Variações do CIM & CIM 50 & CIM 90 \\
\hline \multicolumn{4}{|l|}{ C. parapsilosis $(\mathrm{n}=31)$} \\
\hline Cetoconazol & $0,006-0,75$ & 0,031 & 0,155 \\
\hline Fluconazol & $0,38-24$ & 1,56 & 11,4 \\
\hline 5-Fluorcitosina & $0,002-0,064$ & 0,015 & 0,039 \\
\hline Anfotericina B & $0,008-\geq 32$ & 0,015 & 0,183 \\
\hline Itraconazol & $0,012-3,0$ & 0,086 & 0,95 \\
\hline Voriconazol & $0,012-0,75$ & 0,082 & 0,093 \\
\hline Caspofungina & $0,047-1,5$ & 0,434 & 0,746 \\
\hline \multicolumn{4}{|l|}{ C. albicans $(\mathrm{n}=17)$} \\
\hline Cetoconazol & $0,004-0,125$ & 0,06 & 0,041 \\
\hline Fluconazol & $0,094-2$ & 0,2 & 1,24 \\
\hline 5-Fluorcitosina & $0,004-0,38$ & 0,033 & 0,101 \\
\hline Anfotericina B & $0,006-0,064$ & 0,018 & 0,049 \\
\hline Itraconazol & $0,008-0,75$ & 0,021 & 0,103 \\
\hline Voriconazol & $0,006-0,25$ & 0,008 & 0,02 \\
\hline Caspofungina & $0,032-0,75$ & 0,043 & 0,43 \\
\hline \multicolumn{4}{|l|}{ C. tropicalis $(\mathrm{n}=10)$} \\
\hline Cetoconazol & $0,016-0,38$ & 0,064 & 0,25 \\
\hline Fluconazol & $0,38-12$ & 1,25 & 8 \\
\hline 5-Fluorcitosina & $0,002-0,19$ & 0,098 & 0,094 \\
\hline Anfotericina B & $0,006-0,38$ & 0,19 & 0,315 \\
\hline Itraconazol & $0,032-0,75$ & 0,064 & 0,565 \\
\hline Voriconazol & $0,023-0,19$ & 0,047 & 0,142 \\
\hline Caspofungina & $0,032-2$ & 0,064 & 1 \\
\hline \multicolumn{4}{|l|}{ C. guilliermondii $(\mathrm{n}=08)$} \\
\hline Cetoconazol & $0,006-0,38$ & 0,064 & 0,228 \\
\hline Fluconazol & $0,50-48$ & 2 & 15,6 \\
\hline 5-Fluorcitosina & $0,003-\geq 32$ & 0,002 & 6,6 \\
\hline Anfotericina B & $0,012-1$ & 0,039 & 0,275 \\
\hline Itraconazol & $0,006-8$ & 0,315 & 4 \\
\hline Voriconazol & $0,008-0,25$ & 0,125 & 0,225 \\
\hline Caspofungina & $0,38-1$ & 0,25 & 0,80 \\
\hline \multicolumn{4}{|l|}{ C. krusei $(\mathrm{n}=03)$} \\
\hline Cetoconazol & $0,047-12$ & 0,07 & 8,42 \\
\hline Fluconazol & $4,0-48$ & 4 & 34,8 \\
\hline 5-Fluorcitosina & $0,006-0,023$ & 0,007 & 0,018 \\
\hline Anfotericina B & $0,002-0,19$ & 0,033 & 0,152 \\
\hline Itraconazol & $0,008-\geq 32$ & 0,099 & 22,45 \\
\hline Voriconazol & $0,125-0,25$ & 0,125 & 0,212 \\
\hline Caspofungina & $0,38-0,50$ & 0,28 & 0,084 \\
\hline
\end{tabular}


Tabela 6 (continuação)

Espécies (n)/drogas antifúngicas

CIM $(\mu \mathrm{g} / \mathrm{mL})$

Variações do CIM CIM 50 CIM 90

C. glabrata $(\mathrm{n}=01)$

Cetoconazol

Fluconazol

5-Fluorcitosina

Anfotericina B

Itraconazol

Voriconazol

0,012

ND ND

Caspofungina

* ND - Não determinado

1,5

0,064

0,125

0,006

0,016

0,38
ND ND

ND ND

ND ND

ND ND

ND ND

ND ND 


\subsection{Perfis Genéticos das Amostras de Leveduras}

\subsubsection{Cariotipagem (Eletroforese em campo pulsátil - PFGE) - Amostras Sequenciais}

Através da técnica de PFGE pudemos observar seis cariótipos diferentes de Candida spp nos 24 isolados sequenciais, provenientes de nove pacientes. Cada perfil eletroforético apresentou de 3 a 6 bandas, sendo que os mesmos foram discriminados através de letras (A a F) (Tabela 7 e Figura 3). C. parapsilosis apresentou 4 perfis diferentes (A, B, C e F); C. albicans 3 (A, C e E), C. tropicalis 2 (C e D). No paciente 3 foram isoladas 06 amostras de C. parapsilosis que apresentaram 2 perfis diferentes (B e C). O mesmo fato foi observado nas amostras de C. albicans (A e C); C. tropicalis (C e D) e $C$. parapsilosis (B e F) nos pacientes 4, 5 e 8, respectivamente. No paciente 9, $C$. Krusei e C. parapsilosis apresentaram o mesmo perfil (C). Em alguns pacientes distintos, com espécies diferentes, obtivemos também o mesmo cariótipo. Os isolados de C.albicans do paciente 4, C. parapsilosis do pacientes 1 e 2, C. tropicalis do paciente 5 e C. krusei do paciente 9, apresentaram o mesmo cariótipo (C). O mesmo foi observado entre os isolados de C. parapsilosis dos pacientes 1 e 2 (A) e C. albicans do paciente 4 (A). 
TABELA 7 - Cariótipos obtidos das amostras de Candida associadas com o mesmo paciente.

\begin{tabular}{|c|c|c|c|c|}
\hline Paciente & Amostra & Espécie & Cariótipo & $\begin{array}{c}\mathrm{N}^{\circ} \text { de Bandas (variação do } \\
\text { tamanho - pb) }\end{array}$ \\
\hline \multirow[t]{2}{*}{ P1 } & 1 & C. parapsilosis & $\mathrm{A}$ & $5(945-2200 \mathrm{pb})$ \\
\hline & 2 & C. parapsilosis & A & $5(945-2200 \mathrm{pb})$ \\
\hline \multirow[t]{4}{*}{$\mathbf{P 2}$} & 3 & C. parapsilosis & $\mathrm{A}$ & $5(945-2200 \mathrm{pb})$ \\
\hline & 4 & C. parapsilosis & A & $5(945-2200 \mathrm{pb})$ \\
\hline & 5 & C. parapsilosis & $\mathrm{B}$ & $4(945-2200 \mathrm{pb})$ \\
\hline & 6 & C. parapsilosis & $\mathrm{B}$ & $4(945-2200 \mathrm{pb})$ \\
\hline \multirow[t]{4}{*}{ P3 } & 7 & C. parapsilosis & $\mathrm{B}$ & $4(945-2200 \mathrm{pb})$ \\
\hline & 8 & C. parapsilosis & $\mathrm{C}$ & $5(945-2200 \mathrm{pb})$ \\
\hline & 9 & C. parapsilosis & $\mathrm{C}$ & $5(945-2200 \mathrm{pb})$ \\
\hline & 10 & C. parapsilosis & $\mathrm{B}$ & $4(945-2200 \mathrm{pb})$ \\
\hline \multirow[t]{2}{*}{$\mathbf{P 4}$} & 11 & C. albicans & $\mathrm{C}$ & $5(945-2200 \mathrm{pb})$ \\
\hline & 12 & C. albicans & A & $5(945-2200 \mathrm{pb})$ \\
\hline \multirow[t]{2}{*}{ P5 } & 13 & C. tropicalis & $\mathrm{C}$ & $5(945-2200 \mathrm{pb})$ \\
\hline & 14 & C. tropicalis & $\mathrm{D}$ & $3(1020-2200 \mathrm{pb})$ \\
\hline \multirow[t]{3}{*}{ P6 } & 15 & C. albicans & $\mathrm{E}$ & $5(1020-2200 \mathrm{pb})$ \\
\hline & 16 & C. albicans & $\mathrm{E}$ & $5(1020-2200 \mathrm{pb})$ \\
\hline & 17 & C. parapsilosis & $\mathrm{B}$ & $4(945-2200 \mathrm{pb})$ \\
\hline \multirow[t]{2}{*}{ P7 } & 18 & C. parapsilosis & $\mathrm{B}$ & $4(945-2200 \mathrm{pb})$ \\
\hline & 19 & C. parapsilosis & $\mathrm{B}$ & $4(945-2200 \mathrm{pb})$ \\
\hline \multirow[t]{3}{*}{ P8 } & 20 & C. parapsilosis & $\mathrm{B}$ & $4(945-2200 \mathrm{pb})$ \\
\hline & 21 & C. parapsilosis & $\mathrm{F}$ & $3(945-2200 \mathrm{pb})$ \\
\hline & 22 & C. parapsilosis & $\mathrm{C}$ & $5(945-2200 \mathrm{pb})$ \\
\hline \multirow[t]{2}{*}{ P9 } & 23 & C. krusei & $\mathrm{C}$ & $5(945-2200 \mathrm{pb})$ \\
\hline & 24 & C. parapsilosis & $\mathrm{C}$ & $5(945-2200 \mathrm{pb})$ \\
\hline
\end{tabular}



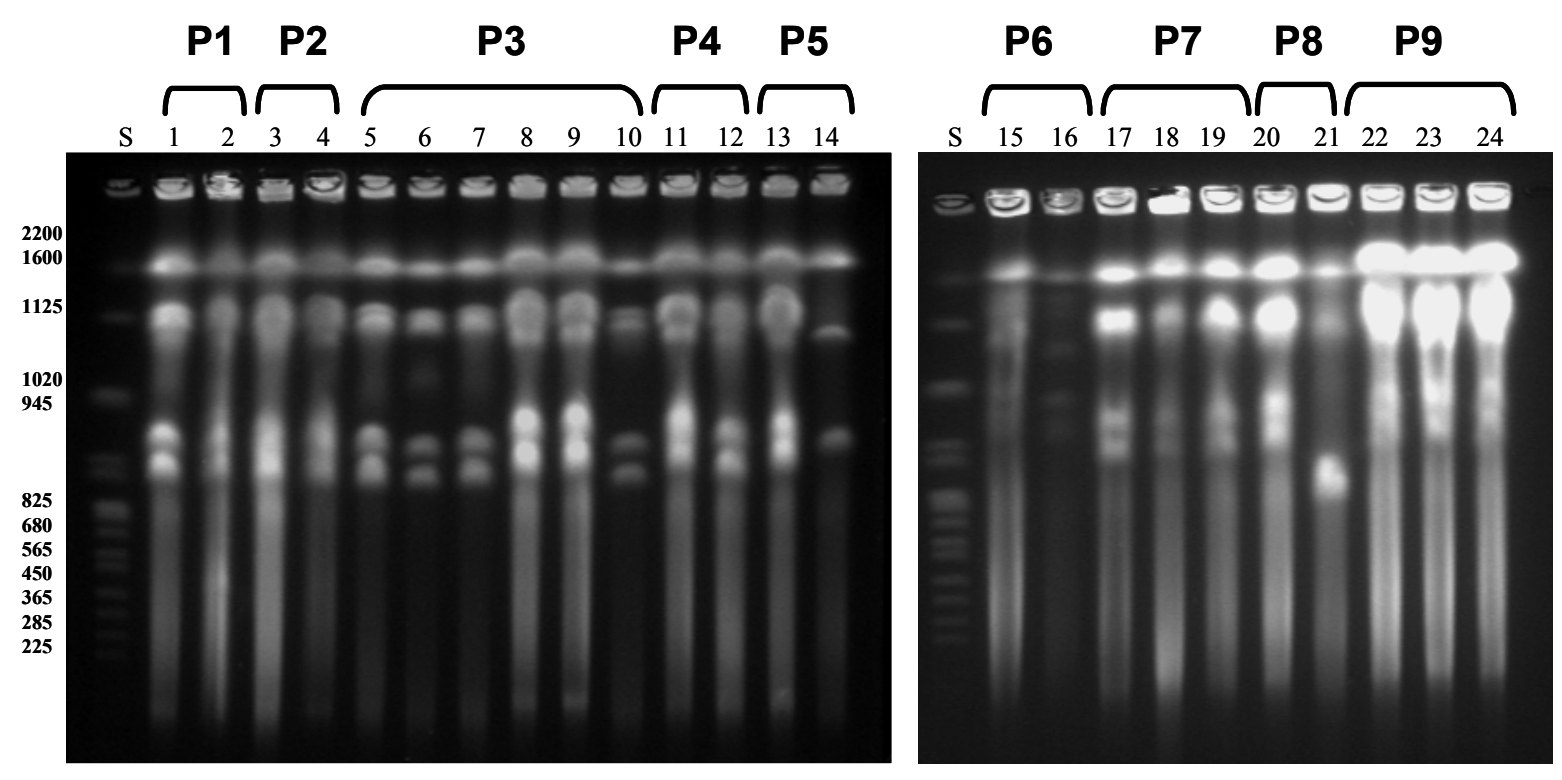

FIGURA 3 - Cariótipos eletroforéticos de amostras de Candida isoladas do mesmo paciente (sangue). S: Padrão de peso molecular (Saccharomyces cerevisiae) (Kb); linhas 1-2: paciente 1; linhas 3-4: paciente 2; linhas 5-10: paciente 3; linhas 11-12: paciente 4; linhas 13-14: paciente 5; linhas 15-16: paciente 6; linhas 17-19: paciente 7; linhas 20-21: paciente 8; linhas 22-24: paciente 9. 


\subsubsection{Comparação entre as Técnicas de Microssatélites e Cariotipagem aplicadas as amostras de $C$. albicans e $C$. parapsilosis}

\subsubsection{Técnica de Microssatélites}

Em relação a técnica de microssatélites, foram testados cinco "primers" para os 17 isolados de $C$. albicans $(C E F 3, E R K 1, C D C 3, E F 3, E R K 1)$ e cada "primer"apresenta como resultado 2 alelos (pb). As tabelas 8 e 9 mostram os resultados obtidos em relação aos comprimentos de pares de bases para cada isolado para os 5 "primers" estudados.

$\mathrm{O}$ “primer" $C D C 3$ apresentou o maior poder discriminatório $(0,86)$, sendo observados 4 alelos diferentes e fragmentos de pares de base que variaram de 119 a 131 pb. Analisando as combinações possíveis destes 4 alelos encontramos 6 perfis genotípicos diferentes para este "primer", sendo que os genótipos mais freqüentes foram 127-127 pb e 123-127 pb. Os "primers" CEF3, ERK1, EF3 e ERK1 apresentaram poder discriminatório de $0,33,0,67,0,75$ e 0,83 , respectivamente.

O poder discriminatório da técnica quando combinamos os cinco marcadores foi de 0,95 , sendo encontrados 24 perfis genotípicos diferentes.

Para as amostras de C. parapsilosis foram estudados três "primers" $(A, B$ e $D)$ apresentando, também, como resultado 2 alelos (pb). A Tabela 10 apresenta os pares de alelos (pb) encontrados para cada isolado em relação aos 3 "primers".

$\mathrm{O}$ "primer" $A$ apresentou o maior poder discriminatório $(0,67)$, apresentando 6 alelos diferentes com fragmentos de pares de base variando entre 107 e 114 pb. Este "primer" mostrou 7 perfis genotípicos diferentes para as 29 amostras de leveduras estudadas, sendo o mais frequente 109-109 pb. Os "primers" $B$ e $D$ mostraram poder discriminatório de 0,56 e 0,40 , respectivamente.

Quando combinamos os três marcadores, observamos que a técnica obteve um poder discriminatório de 0,84 e um total de 17 genótipos diferentes. 
TABELA 8 - Comprimentos de pares de bases, pela análise de PCR, de 17 isolados de Candida albicans, empregando-se os "primers" CEF3 e ERK1.

\begin{tabular}{ccccc}
\hline & \multicolumn{2}{c}{ Primer CEF3 } & \multicolumn{2}{c}{ Primer ERK1 } \\
\cline { 2 - 5 } Amostras & Alelo 1 (pb) & Alelo 2 (pb) & Alelo 1(pb) & Alelo 2 (pb) \\
\hline H-827 & 133 & 133 & 235 & 243 \\
H-840 & 127 & 137 & 235 & 243 \\
H-848 & 127 & 137 & 243 & 243 \\
H-515 & 127 & 137 & 235 & 243 \\
H-2171 & 127 & 137 & 235 & 243 \\
H-2158 & 127 & 137 & 243 & 243 \\
H-268 & 127 & 137 & 243 & 243 \\
H-674 & 138 & 141 & 235 & 235 \\
H-1303 & 127 & 137 & 243 & 243 \\
H-424 & 127 & 137 & 235 & 235 \\
H-1223 & 127 & 137 & 243 & 243 \\
H-1558 & 132 & 141 & 243 & 243 \\
H-1406 & 127 & 137 & 235 & 235 \\
H-687 & 127 & 137 & 243 & 246 \\
H-1060 & 127 & 137 & 243 & 243 \\
H-118 & 127 & 137 & 243 & 243 \\
H-1683 & 127 & 137 & 243 & 243 \\
\hline
\end{tabular}


TABELA 9 - Comprimentos de pares de bases, pela análise de PCR, de 17 isolados de Candida albicans, empregando-se os "primers" CDC3, EF3 e HIS3.

\begin{tabular}{lcccccc}
\hline & \multicolumn{2}{c}{ Primer CDC3 } & \multicolumn{2}{c}{ Primer EF3 } & \multicolumn{2}{c}{ Primer HIS3 } \\
\cline { 2 - 7 } Amostras & Alelo 1 & Alelo 2 & Alelo 1 & Alelo 2 & Alelo 1 & Alelo 2 \\
& $\mathbf{( p b )}$ & $\mathbf{( p b )}$ & $\mathbf{( p b )}$ & $\mathbf{( p b )}$ & $\mathbf{( p b )}$ & $\mathbf{( p b )}$ \\
\hline H-827 & 119 & 131 & 135 & 135 & 158 & 162 \\
H-840 & 127 & 127 & 131 & 131 & 162 & 162 \\
H-848 & 119 & 131 & 135 & 135 & 158 & 162 \\
H-515 & 127 & 127 & 145 & 145 & 217 & 217 \\
H-2171 & 123 & 127 & 145 & 145 & 150 & 191 \\
H-2158 & 123 & 127 & 145 & 145 & 150 & 191 \\
H-268 & 119 & 127 & 137 & 137 & 162 & 162 \\
H-674 & 123 & 123 & 135 & 135 & 158 & 162 \\
H-1303 & 119 & 119 & 135 & 135 & 150 & 191 \\
H-424 & 127 & 127 & 131 & 131 & 162 & 162 \\
H-1223 & 123 & 127 & 145 & 145 & 217 & 217 \\
H-1558 & 127 & 127 & 145 & 145 & 217 & 217 \\
H-1406 & 123 & 127 & 140 & 140 & 150 & 191 \\
H-687 & 119 & 127 & 145 & 145 & 217 & 217 \\
H-1060 & 123 & 123 & 131 & 131 & 161 & 161 \\
H-118 & 123 & 123 & 145 & 145 & 161 & 161 \\
H-1683 & 119 & 127 & 135 & 135 & 150 & 191 \\
\hline
\end{tabular}


TABELA 10 - Comprimentos de pares de bases, pela análise de PCR, de 29 isolados de Candida parapsilosis, empregando-se os "primers" $A, B$ e $D$.

\begin{tabular}{|c|c|c|c|c|c|c|}
\hline \multirow{2}{*}{ Amostras } & \multicolumn{2}{|c|}{ Primer $A$} & \multicolumn{2}{|c|}{ Primer $B$} & \multicolumn{2}{|c|}{ Primer D } \\
\hline & Alelo 1 (pb) & Alelo 2 (pb) & Alelo 1 (pb) & Alelo 2 (pb) & Alelo 1 (pb) & Alelo 2 (pb) \\
\hline H-1759 & 107 & 109 & 131 & 131 & 137 & 137 \\
\hline H-2503 & 114 & 114 & 112 & 112 & 137 & 137 \\
\hline H-2484 & 114 & 114 & 112 & 112 & 137 & 137 \\
\hline H-2514 & 114 & 114 & 112 & 112 & 137 & 137 \\
\hline H-2030 & 109 & 109 & 132 & 132 & 137 & 137 \\
\hline H-2174 & 109 & 109 & 132 & 132 & 137 & 137 \\
\hline H-1566 & 110 & 110 & 112 & 112 & 134 & 134 \\
\hline H-2480 & 109 & 109 & 132 & 132 & 137 & 137 \\
\hline H-1153 & 112 & 112 & 108 & 108 & 137 & 137 \\
\hline H-2794 & 109 & 109 & 132 & 132 & 137 & 137 \\
\hline H-2434 & 109 & 109 & 132 & 132 & 137 & 137 \\
\hline H-2471 & 109 & 109 & 132 & 132 & 137 & 139 \\
\hline H-2526 & 109 & 109 & 132 & 132 & 137 & 137 \\
\hline H-2175 & 112 & 112 & 108 & 108 & 134 & 134 \\
\hline H-2538 & 109 & 109 & 132 & 132 & 137 & 137 \\
\hline H-1356 & 114 & 114 & 131 & 131 & 137 & 137 \\
\hline H-2153 & 110 & 110 & 142 & 142 & 137 & 137 \\
\hline H-861 & 109 & 109 & 132 & 132 & 134 & 134 \\
\hline H-2259 & 109 & 109 & 132 & 132 & 137 & 137 \\
\hline H-541 & 109 & 109 & 132 & 132 & 137 & 137 \\
\hline H-2016 & 109 & 109 & 132 & 132 & 137 & 137 \\
\hline H-2339 & 109 & 109 & 132 & 132 & 137 & 137 \\
\hline H-818 & 107 & 109 & 132 & 132 & 139 & 139 \\
\hline H-488 & 112 & 112 & 131 & 131 & 134 & 134 \\
\hline H-1480 & 109 & 111 & 132 & 132 & 137 & 137 \\
\hline H-2289 & 109 & 109 & 132 & 132 & 134 & 134 \\
\hline H-2278 & 111 & 111 & 148 & 148 & 137 & 137 \\
\hline H-2246 & 109 & 109 & 132 & 132 & 137 & 137 \\
\hline H-496 & 109 & 109 & 132 & 132 & 137 & 137 \\
\hline
\end{tabular}




\subsubsection{Técnica de PFGE}

Com a técnica de PFGE pudemos observar nove cariótipos diferentes entre as 17 amostras de C. albicans pesquisadas. Cada perfil eletroforético apresentou de 1 a 5 bandas (variando de $825-2200 \mathrm{pb}$ ), sendo que os mesmos foram discriminados através de letras (A a I) (Tabela 11 e Figura 4). O poder discriminatório da técnica foi de 0,90.

Em relação as amostras de C. parapsilosis, os resultados mostraram nove perfis de cariótipos, entre as 29 amostras, com poder discriminatório de 0,62. Os perfis apresentaram de 2 a 6 bandas (variando de $450-2200 \mathrm{pb}$ ), sendo estas identificadas através das letras J a S (Tabela 12 e Figura 5). 
TABELA 11 - Cariótipos obtidos das amostras de Candida albicans.

\begin{tabular}{|c|c|c|c|}
\hline Amostra & $\mathrm{N}^{\circ} \mathrm{ICB}$ & Cariótipo & $\mathrm{N}^{\circ}$ de Bandas (variação do tamanho - pb) \\
\hline 1 & H-827 & G & $3(825 \mathrm{pb}-2200 \mathrm{pb})$ \\
\hline 2 & H-848 & $\mathrm{C}$ & $5(825 \mathrm{pb}-2200 \mathrm{pb})$ \\
\hline 3 & H-1406 & $\mathrm{F}$ & $1(2220 \mathrm{pb})$ \\
\hline 4 & H-1303 & $\mathrm{F}$ & $1(2220 \mathrm{pb})$ \\
\hline 5 & H-1223 & $\mathrm{F}$ & $1(2220 p b)$ \\
\hline 6 & $\mathrm{H}-840$ & $\mathrm{H}$ & $5(825 \mathrm{pb}-2200 \mathrm{pb})$ \\
\hline 7 & H-1558 & I & $3(825 \mathrm{pb}-2200 \mathrm{pb})$ \\
\hline 8 & H-687 & A & $2(1125 \mathrm{pb}-1600 \mathrm{pb})$ \\
\hline 9 & H-1060 & $\mathrm{B}$ & $4(825 p b-1600 p b)$ \\
\hline 10 & H-424 & $\mathrm{C}$ & $5(825 \mathrm{pb}-2200 \mathrm{pb})$ \\
\hline 11 & H-1683 & A & $2(1125 \mathrm{pb}-1600 \mathrm{pb})$ \\
\hline 12 & H-118 & $\mathrm{D}$ & $3(1020 \mathrm{pb}-1600 \mathrm{pb})$ \\
\hline 13 & H-515 & $\mathrm{E}$ & $5(1020 \mathrm{pb}-1600 \mathrm{pb})$ \\
\hline 14 & H-674 & $\mathrm{E}$ & $5(1020 \mathrm{pb}-1600 \mathrm{pb})$ \\
\hline 15 & H-2158 & $\mathrm{E}$ & $5(1020 \mathrm{pb}-1600 \mathrm{pb})$ \\
\hline 16 & H-2171 & $\mathrm{E}$ & $5(1020 \mathrm{pb}-1600 \mathrm{pb})$ \\
\hline 17 & H-268 & $\mathrm{F}$ & $1(2220 p b)$ \\
\hline
\end{tabular}


TABELA 12 - Cariótipos obtidos das amostras de Candida parapsilosis.

\begin{tabular}{|c|c|c|c|}
\hline Amostra & $\mathbf{N}^{\circ} \mathrm{ICB}$ & Cariótipo & $N^{\circ}$ de Bandas (variação do tamanho - pb) \\
\hline 1 & H-2174 & $\mathrm{J}$ & $6(450 \mathrm{pb}-2200 \mathrm{pb})$ \\
\hline 2 & H-2030 & $\mathrm{L}$ & $5(945 \mathrm{pb}-2200 \mathrm{pb})$ \\
\hline 3 & H-1759 & M & $5(825 \mathrm{pb}-2200 \mathrm{pb})$ \\
\hline 4 & H-2503 & M & $5(825 \mathrm{pb}-2200 \mathrm{pb})$ \\
\hline 5 & H-2484 & $\mathrm{N}$ & $5(825 \mathrm{pb}-2200 \mathrm{pb})$ \\
\hline 6 & H-2514 & $\mathrm{O}$ & $3(1125 \mathrm{pb}-2200 \mathrm{pb})$ \\
\hline 7 & H-1566 & $\mathrm{O}$ & $3(1125 \mathrm{pb}-2200 \mathrm{pb})$ \\
\hline 8 & H-2480 & $\mathrm{N}$ & $5(825 \mathrm{pb}-2200 \mathrm{pb})$ \\
\hline 9 & H-1153 & $\mathrm{P}$ & $4(825 \mathrm{pb}-2200 \mathrm{pb})$ \\
\hline 10 & H-2434 & $\mathrm{N}$ & $5(825 \mathrm{pb}-2200 \mathrm{pb})$ \\
\hline 11 & H-2471 & $\mathrm{N}$ & $5(825 \mathrm{pb}-2200 \mathrm{pb})$ \\
\hline 12 & H-2526 & $\mathrm{N}$ & $5(825 \mathrm{pb}-2200 \mathrm{pb})$ \\
\hline 13 & H-2153 & $\mathrm{N}$ & $5(825 \mathrm{pb}-2200 \mathrm{pb})$ \\
\hline 14 & H-2175 & Q & $5(565 p b-2200 p b)$ \\
\hline 15 & H-2538 & $\mathrm{N}$ & $5(825 \mathrm{pb}-2200 \mathrm{pb})$ \\
\hline 16 & H-2339 & $\mathrm{N}$ & $5(825 \mathrm{pb}-2200 \mathrm{pb})$ \\
\hline 17 & H-496 & $\mathrm{N}$ & $5(825 p b-2200 p b)$ \\
\hline 18 & H-2289 & $\mathrm{N}$ & $5(825 p b-2200 p b)$ \\
\hline 19 & H-488 & $\mathrm{N}$ & $5(825 p b-2200 p b)$ \\
\hline 20 & H-861 & $\mathrm{N}$ & $5(825 \mathrm{pb}-2200 \mathrm{pb})$ \\
\hline 21 & H-2278 & $\mathrm{N}$ & $5(825 \mathrm{pb}-2200 \mathrm{pb})$ \\
\hline 22 & H-1356 & $\mathrm{N}$ & $5(825 p b-2200 p b)$ \\
\hline 23 & H-541 & $\mathrm{N}$ & $5(825 \mathrm{pb}-2200 \mathrm{pb})$ \\
\hline 24 & H-818 & $\mathrm{N}$ & $5(825 \mathrm{pb}-2200 \mathrm{pb})$ \\
\hline 25 & H-2246 & $\mathrm{N}$ & $5(825 \mathrm{pb}-2200 \mathrm{pb})$ \\
\hline 26 & H-2794 & $\mathrm{N}$ & $5(825 \mathrm{pb}-2200 \mathrm{pb})$ \\
\hline 27 & H-1480 & $\mathrm{R}$ & $3(825 \mathrm{pb}-2200 \mathrm{pb})$ \\
\hline 28 & H-2016 & $\mathrm{J}$ & $6(450 \mathrm{pb}-2200 \mathrm{pb})$ \\
\hline 29 & H-2259 & $\mathrm{S}$ & $2(1020 p b-2200 p b)$ \\
\hline
\end{tabular}




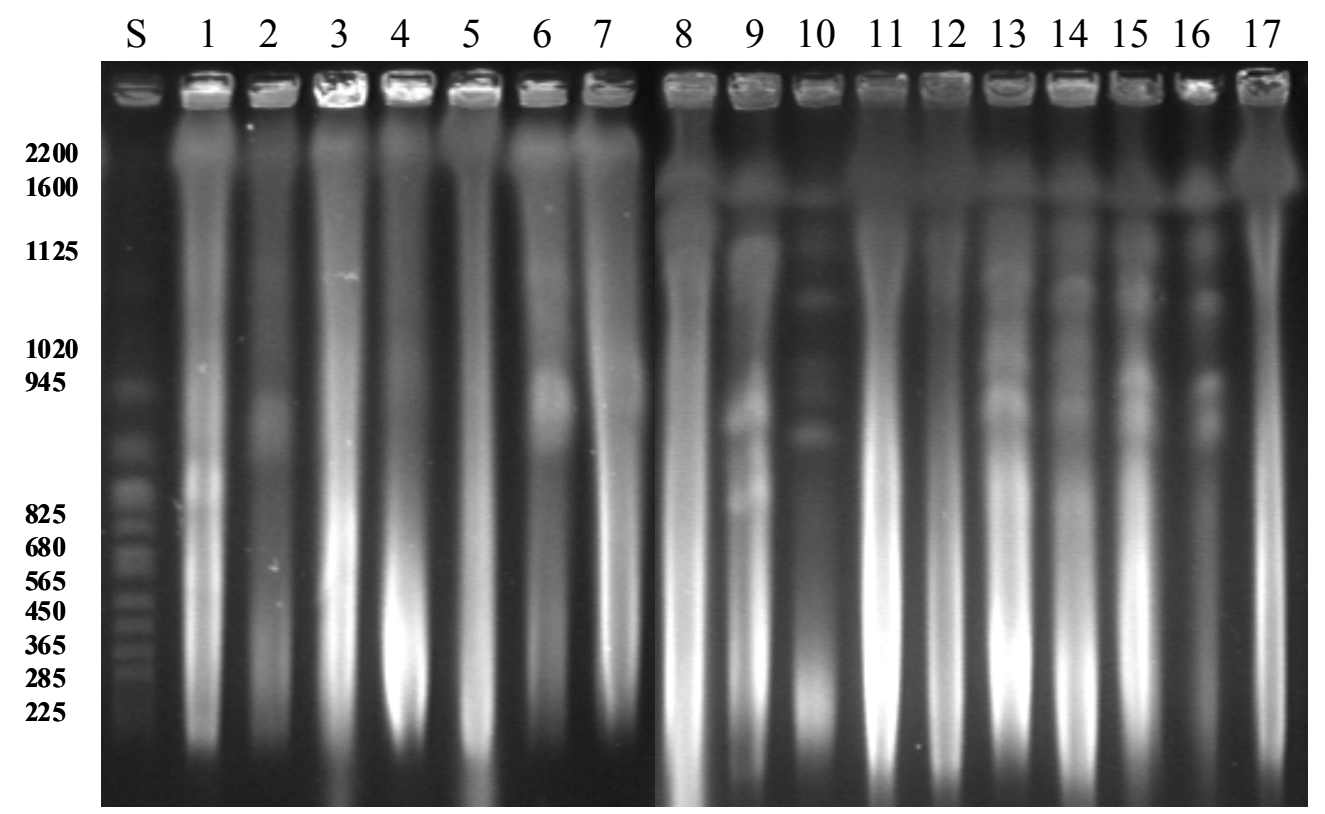

FIGURA 4 - Cariótipos eletroforéticos de 17 amostras de C. albicans isoladas de sangue. S: Padrão de peso molecular (Saccharomyces cerevisiae) (Kb); linhas 1-17: amostras de $C$. albicans.

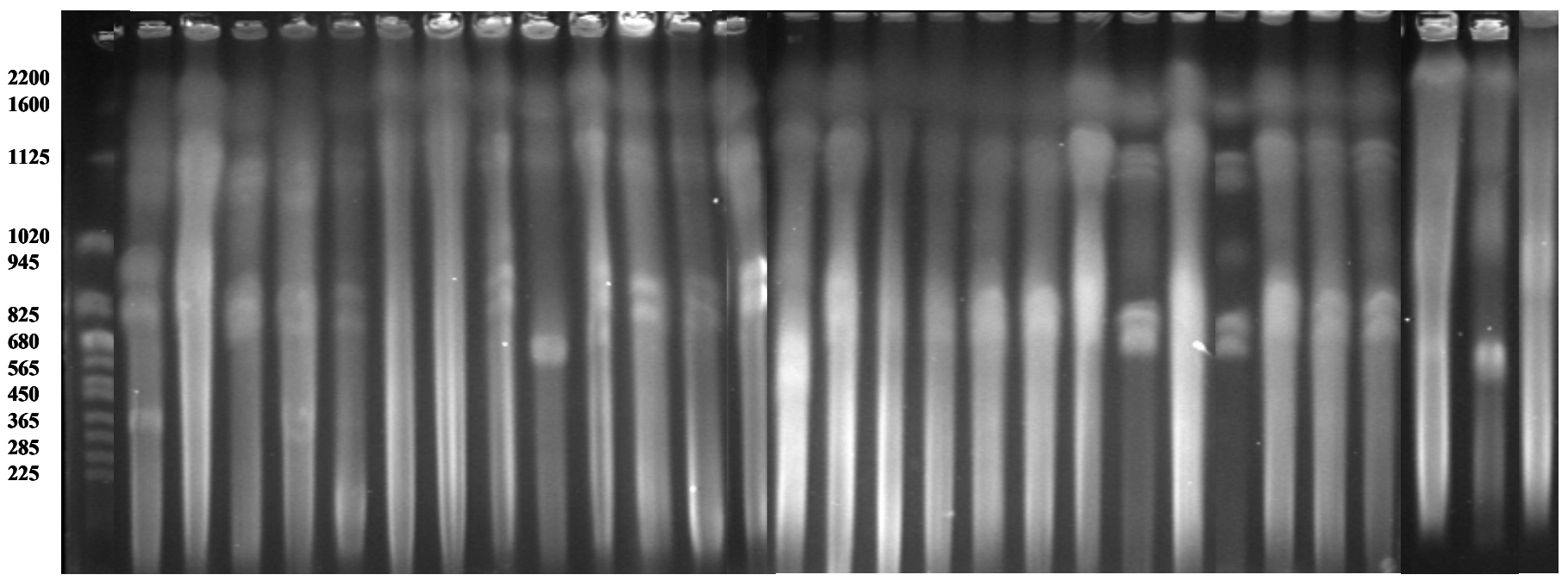

FIGURA 5 - Cariótipos eletroforéticos de 29 amostras de C. parapsiolosis isoladas de sangue. S: Padrão de peso molecular (Saccharomyces cerevisiae) (Kb); linhas 1-17: amostras de C. parapsilosis. 
Por meio da comparação dos perfis genotípicos obtidos, analisamos a concordância das amostras em metodologias diferentes (PFGE e microssatélite), ou seja, se a similaridade molecular entre as amostras seria a mesma em ambas as metodologias. Para os isolados de $C$. albicans observamos similaridades moleculares entre ambas as técnicas em 4, 2, 4, 3 e 2 amostras para os "primers" CEF3, ERK1, CDC3, EF3 e HIS3, respectivamente (Tabelas 8, 9 e 11). Para os isolados de C. parapsilosis obtivemos similaridades moleculares entre as metodologias empregadas em 12, 18 e 19 amostras para os "primers" $A, B$ e $C$, respectivamente (Tabelas 9 e 12).

\subsection{Comparação entre os Perfis Genotípicos e Sensibilidade aos Antifúngicos}

Comparamos os perfis genotípicos obtidos através das técnicas de microssatélites e PFGE com os perfis de sensibilidade antifúngica, e não observamos nenhuma correlação, uma vez que os valores de MICs mostraram-se similares em todas as amostras.

As amostras com CIMs elevados tinham perfil genotípico igual a outras inúmeras amostras (Tabelas 5 e 6). 
DISCUSSÃO 


\section{DISCUSSÃO}

\subsection{Re-caracterização das Amostras de Leveduras}

O aumento na incidência de infecções leveduriformes tem estimulado o desenvolvimento de sistemas comerciais manuais e automatizados para identificação destes microrganismos (CAMPBELL et al., 1999). O sistema API 20C (bioMerieux, Marcy-1'Etoile, France) foi um dos primeiros sistemas comerciais a ser introduzido em pesquisas para identificação de leveduras (BUESCHING et al., 1979). Em 1979, LAND e colaboradores, relataram uma concordância de $96 \%$ entre as identificações obtidas pelo método convencional e o sistema API 20C. Atualmente é considerado um sistema aprovado e confiável, com o qual outros estão sendo comparados (ESPINEL-INGROFF et al., 1998; HEELAN et al., 1998; XU et al., 2002).

Neste estudo, o sistema API 20C identificou igualmente 93\% das 70 amostras pesquisadas quando comparado ao método tradicional. Este resultado é comparável com aqueles observados por outros autores (EL-ZAATARI et al., 1990; ST. GERMAIN et al., 1991). Fenn et al. (1994) relataram que 99\% das leveduras isoladas foram identificadas corretamente pelo API 20C, quando comparadas ao método tradicional, enquanto Davey et al. (1995) encontraram $88 \%$ de identificações corretas com este sistema. Campbell et al. (1999) observaram uma taxa de identificação correta de 91,8\%.

Utilizando 178 isolados identificados pelo método convencional, Schuffenecker et al. (1993), avaliaram quatro sistemas comerciais para identificação de leveduras. O "kit" que apresentou maior taxa de concordância foi o API $20 \mathrm{C}(86.5 \%)$, seguido por Auxacolor (86\%), Mycotube (68\%) e Candifast (51.1\%).

Chen et al. (2000), em estudos comparativos, observaram que o API 20C mostrou-se mais seguro na identificação de isolados de leveduras comuns (97\%) e raros (88\%) que o API 32C, o qual pode seguramente identificar $92 \%$ e $85 \%$, respectivamente.

$\mathrm{Xu}$ et al. (2002) realizaram uma comparação do API 20C com a identificação molecular de 58 isolados de Candida spp provenientes de infecções sanguíneas. Para identificação genotípica utilizaram o PCR e sequenciamento direto da região ITS2. Os autores observaram que do total de amostras estudadas, apenas um isolado não mostrou 
concordância entre os métodos, sendo que o sistema API $20 \mathrm{C}$ identificou como $C$. albicans e o método molecular como C. dubliniensis.

Segundo Ramani et al. (1998), embora este sistema seja efetivo na identificação de leveduras comumente isoladas, sua aplicação é algumas vezes mais limitada na identificação acurada de espécies mais raras. Esta limitação, de acordo com o autor, é provavelmente atribuída, em parte, a base de dados aplicada no índice de perfis bioquímicos. Em nosso estudo tal fato não pode ser corroborado, uma vez que nenhuma levedura rara foi isolada no Hospital Público em estudo.

Em nossa pesquisa, o API 20C mostrou ser um sistema eficaz, rápido e de fácil execução. Tais características tornam-se de grande importância para o clínico pois, além do aspecto epidemiológico, uma identificação leveduriforme rápida e eficaz ao nível de espécie, faz-se fundamental para permitir a escolha da melhor abordagem terapêutica a ser instituída no paciente infectado (COLOMBO e GUIMARÃES, 2003).

\subsection{Diferenciação entre $C$. albicans e $C$. dubliniensis}

C. dubliniensis é uma levedura recentemente descrita como patógeno oportunista associado a candidiase oral, particularmente em indivíduos HIV positivos e pacientes com AIDS (SULLIVAN et al., 1998). No entanto, o isolamento de C. dubliniensis de outras fontes clínicas, obtidas de pacientes HIV negativos, tem sido relatado com menor freqüência, incluindo urina, vagina, fezes de pacientes diabéticos, sítios cirúrgicos, transplantados e sangue (MEIS et al. 1999, BRANDT et al. 2000, WILLIS et al. 2000).

O primeiro caso de fungemia por C. dubliniensis foi descrito na Europa em três pacientes transplantados de medula óssea e neutropênicos (MEIS et al., 1999). Brandt et al. (2000) registrou os primeiros quatro casos de fungemia por esta espécie de Candida na América do Norte. Desde então, novos estudos observaram a presença de $C$. dublinensis como agente etiológico de fungemia (GOTTLIEB et al., 2001, MARRIOTT et al., 2001, BOYLE et al., 2002, CIMOLAI et al., 2002, McMULLAN et al., 2002, JABRA-RIZK et al., 2005, MUBAREKA et al., 2005, VAN HAL et al., 2008). No entanto, a incidêcia, importância clínica, características epidemiológicas e conseqüências da candidemia por $C$. dubliniensis não estão bem esclarecidas. 
Esta espécie é fenotipicamente semelhante a $C$. albicans o que tem gerado problemáticas na identificação de isolados clínicos (GIAMMANCO et al., 2002), bem como a re-identificação de isolados mantidos em coleções de leveduras inicialmente identificados como C. albicans (PONTÓN et al., 2000).

Em estudo retrospectivo realizado em uma coleção de leveduras, os autores demonstraram que $2 \%$ dos isolados originalmente identificados como C. albicans eram amostras de $C$. dubliniensis (COLEMAN et al., 1997). Odds et al. (1998) realizaram uma reidentificação de 2589 culturas mantidas em micoteca e inicialmente identificadas como C. albicans. Do total de culturas estudadas, $2.1 \%$ foram reidentificadas como $C$. dubliniensis. Jabra-Rizk et al. (2000) obteve uma prevalência de C. dubliniensis de 1,2\% entre 1251 isolados originalmente identificados como C. albicans. Colombo et al. (2003) investigaram a presença de $C$. dubliniensis entre 548 isolados mantidos em coleção e previamente identificados como C. albicans. Os autores constataram a presença de 11 isolados reidentificados como C. dubliniensis.

Segundo Mariano et al. (2003), na América do Sul, a prevalência de isolados de C. dubliniensis parece ser menor do que aquela exibida por países da América do Norte.

A incidência de C. dubliniensis, em pacientes HIV positivos e com AIDS, observada no Brasil mostra-se menor do que na Europa e EUA. Milan et al. (2001) realizaram o primeiro estudo prospectivo multicêntrico da incidência oral de $C$. dubliniensis em pacientes brasileiros com AIDS e HIV positivos. No período de dois anos, foram pesquisados seis centros médicos terciários com atividades no tratamento de pacientes HIV em todo Brasil. De um total de 155 amostras isoladas, 2.8\% foram identificadas como C. dubliniensis. Ainda no Brasil, Chavasco et al. (2006) isolaram 37 amostras de Candida de pacientes HIV positivos e negativos com candidíase oral, sendo que destes 5,4\% eram $C$. dubliniensis. Em estudo realizado na Irlanda, constatou-se uma incidência de C. dubliniensis variando de 18 a 32\% em indivíduos infectados com HIV (COLEMAN et al., 1997; SULLIVAN et al., 1999), enquanto pesquisas conduzidas nos EUA têm relatado taxas de 11.1 a 17.5\% (KIRKPATRICK et al., 1998; MEILLER et al. 1999).

Vários métodos fenotipicos para discriminação e identificação de C. dubliniensis têm sido relatados, incluindo aqueles utilizados neste estudo, sendo estes a cultura em 
meio CHROMagar Candida e a avaliação da habilidade de crescimento a temperatura de $42^{\circ} \mathrm{C}$ (SULLIVAN et al., 1995, 1997). Estes testes têm sido utilizados por vários autores, e mostram-se de rápida execução e fácil manuseio, gerando resultados rápidos com critérios claros de leitura (SCHOOFS et al., 1997; SULLIVAN e COLEMAN, 1997; KIRKPATRICK et al., 1998; TINTELNOT et al., 2000).

Uma maneira segura e usual de identificação de $C$. dubliniensis são os testes genotípicos. Esta análise indica que a organização do genoma de $C$. dubliniensis é distinta da de C. albicans. Análises de DNA de diferentes amostras de C. dubliniensis tem demonstrado que a mesma apresenta seqüências conservadas de elementos de DNA sendo útil na identificação das amostras fazendo o diagnóstico diferencial de infecções por C. albicans (JOLY et al., 1999).

Neste estudo, 17 amostras isoladas de sangue e originalmente identificadas como C. albicans foram re-identificadas de acordo com suas características fenotípicas e genotípicas. Demonstramos que todas as amostras estão corretamente identificadas como C. albicans. Este resultado estaria de acordo com a baixa incidência de $C$. dubliniensis na América do Sul, principalmente no que se refere a casos de candidemia onde o isolamento desta espécie torna-se ainda menor.

Uma única amostra em nosso estudo, apesar de ter apresentado crescimento a temperatura de $42^{\circ} \mathrm{C}$ e características genotípicas de C. albicans, não exibiu colônias com coloração verde claro sobre o meio CHROMagar. Talvez isto possa ser explicado pelo fato de se tratarem de amostras mantidas em micoteca por um longo período de tempo, com isso elas perdem sua capacidade de exibir coloração típica quando semeada sobre este meio cromogênico (SCHOOFS et al., 1997; SULLIVAN et al., 1999).

\subsection{Sensibilidade Antifúngica}

Infecções fúngicas causadas por espécies de Candida são de interesse especial por duas razões: primeiro pela virulência e patogenicidade; segundo pela ocorrência de resistência às drogas antifúngicas atualmente disponíveis (DIEKEMA et al., 2002). Salienta-se a necessidade de uma vigilância contínua no que se refere aos padrões de 
sensibilidade aos antifúngicos, não somente para se evitar casos de resistência, mas para prevenir e controlar as infecções fúngicas nosocomiais.

Aplicando-se os valores de "breakpoints" de sensibilidade e resistência indicados pelo CLSI, neste estudo, podemos observar um alto índice de sensibilidade da maioria das amostras para todas as drogas antifúngicas estudadas.

C. guilliermondii apresentou três isolados resistentes ao itraconazol e um resistente a 5-fluorcitosina, sendo esta a espécie que demonstrou o maior número de amostras resistentes. Esta espécie tem sido mais relacionada com resistência a anfotericina B (DICK et al., 1985; PFALLER et al., 2003) e fluconazol (ESPINELINGROFF et al., 1998, 2001). Alguns trabalhos demostraram que isolados de $C$. guilliermondii parecem ser menos sensíveis ao fluconazol que outras espécies de Candida mais comuns, como C. albicans, C. parapsilosis e C. tropicalis (PFALLER et al., 2002; PFALLER et al., 2003). Em nosso estudo todas as amostras mostraram-se sensíveis ao fluconazol, porém suas CIMs mostraram-se mais elevadas do que para as demais espécies $(0,5 \mathrm{a} 48 \mu \mathrm{g} / \mathrm{mL})$.

Os isolados de $C$. parapsilosis mostraram-se sensíveis a todos os antifúngicos testados, a exceção de uma única amostra que apresentou-se resistente a anfotericina B. Este é um dado interessante, uma vez que geralmente isolados clínicos desta espécie são sensíveis a esta droga e aos triazólicos (DIEKEMA et al., 2002; SANGLARD e ODDS, 2002). A resistência "in vitro" a anfotericina B tem sido associada com fungemia persistente em pacientes pediátricos (KOVACICOVA et al., 2001). Em adição, $C$. parapsilosis tem sido observada como tolerante a anfotericina B em concetrações alcançadas em soro de pacientes (CANTON et al., 2004). Zaoutis et al. (2005) realizaram um estudo de sensibilidade antifúngica com espécies de Candida, e constataram que 20\% dos isolados de $C$. parapsilosis possuíam resistência a anfotericina B.

Todos os isolados de C. krusei apresentaram-se sensíveis ao fluconazol, sendo que $66,6 \%$ mostraram valores de $\mathrm{CIM} \leq 4 \mu \mathrm{g} / \mathrm{mL}$. Tal dado contraria trabalhos da literatura que mostram valores de CIM elevados e na maioria das vezes confirmando a resistência inata desta espécie ao fluconazol (KOÇ et al., 2000; POSTERARO et al., 2000; MORACE et al., 2002). 
O único isolado de C. glabrata mostrou valor de CIM baixo para o fluconazol, não corroborando com os dados da literatura que mostram que cerca de $10 \%$ das amostras de C. glabrata recuperadas do sangue são resistentes ao fluconazol (PFALLER et al., 2000; DIEKEMA et al., 2002) e 20\% desenvolvem resistência durante a terapia ou profilaxia (REX et al., 1995). No Brasil, Colombo et al. (2003) observaram que as nove amostras de C. glabrata isoladas, tiveram CIMs mais baixos que os geralmente encontrados e desses apenas um foi resistente ao fluconazol. Estes dados podem estar relacionados com a menor freqüência do uso de fluconazol no Brasil do que nos EUA ou na Europa. Na Ásia, Yang et al. (2005), realizaram um estudo de sensibilidade com amostras de Candida coletadas em hospitais pertencentes ao TSARY ("Taiwan Surveillance of Antimicrobial Resistance of Yeasts") e constataram que de 1999 a 2002 houve uma baixa da taxa de resistência ao fluconazol de 8,4\% para 1,9\%, respectivamente.

Em relação aos isolados de C. tropicalis, todos mostraram-se sensíveis às seis drogas antifúngicas testadas, sendo que para o fluconazol $80 \%$ foram considerados sensíveis e 20\% sensíveis dose-dependente. Estes dados não vão de acordo com a literatura que mostra que $10 \%-25 \%$ dos isolados desta espécie possuem resistência inerente ou secundária ao fluconazol (KRCMERY e BARNES, 2002).

Estudos relacionados à resistência aos antifúngicos demonstraram que espécies não albicans estão associadas a maior índice de resistência (COLOMBO et al., 2003). Em nosso estudo os isolados de C. albicans mostraram-se sensíveis a todos os antifúngicos testados.

Em relação à caspofungina,, espécies de Candida apresentam sensibilidade intrinsica a caspofungina, e embora a anfotericina B seja o tratamanto "gold standart" para infecções sistêmicas por estas leveduras, a caspofungina vem tornando-se uma droga promissora junto a estas infecções pela sua baixa toxicidade e eficácia clínica (MADSEN et al., 2006).

As equinocandinas, de um modo geral, demonstram excelente atividade junto as espécies de Candida, incluíndo aquelas resistentes aos poliênicos e azóis (PFALLER et al., 2008). Em estudos multicêntricos, a caspofungina mostrou-se tão eficiente quanto a 
anfotericina B no tratamento primário de candidemia e outras infecções por Candida (MORA-DUARTE et al., 2002; KARTSONIS et al., 2004).

Em nosso estudo, todos os isolados mostraram sensibilidade a caspofungina. Pfaller et al. (2008) em estudo realizado com diferentes espécies de Candida, também observaram uma sensibilidade a caspofungna variando de 98 a 100\%. Na pesquisa, os autores consideraram sensíveis, amostras com CIM $\leq 2 \mu \mathrm{g} / \mathrm{mL}$, seguindo critério determinado em junho de 2007 pelo CLSI (não publicado), sendo que até então, não existia uma padronização do "breakpoint" para esta droga. Para tal o CLSI levou em consideração a distribuição dos CIMs gerados pela sobrevivência "in vitro", os mecanismos de ação e resistência das equinocandinas, a farmacocinética e farmacodinâmica da droga e a eficácia clínica de cada agente em relação ao CIM do isolado infectante. Em nosso estudo utlizamos, também, este CIM para definir a sensibilidade e a resistência dos isolados de sangue estudados..

Neste estudo, apesar de todos os isolados mostrarem sensibilidade a caspofungina, três isolados de $C$. parapsilosis e um de $C$. tropicalis apresentaram valores elevados de CIM (entre 1 e $2 \mu \mathrm{g} / \mathrm{mL}$ ). Valores altos de CIMs, em algumas espécies de Candida, também foram encontrados por alguns autores (PFALLER et al., 2006; PFALLER et al., 2008), que sugerem diferenças biológicas, na sensibilidade a caspofungina, entre estes isolados e aqueles com valores de CIMs menores.

Assim, notamos que as espécies de Candida possuem diferentes graus de sensibilidade às drogas antifúngicas mais comuns, apesar dos baixos valores de CIMs. Este fenômeno enfatiza a importância da identificação e controle das espécies de Candida na clínica médica (YANG et al., 2005). Além disso, as pesquisas mostram a necessidade de um monitoramento epidemiológico, juntamente com uma vigilância contínua nos padrões de sensibilidade aos antifúngicos, assim como mais trabalhos associando resistência-sensibilidade às demais características biológicas das leveduras.

Vale aqui salientar que este estudo foi realizado com um método comercial o Ëtest", porém de alta concordância com o método de referência do CLSI (ESPINELINGROFF et al., 1996; POSTERARO et al., 2000, SILVA et al., 2002). 


\subsection{Perfis Genéticos das Amostras de Leveduras}

\subsubsection{Cariotipagem - Eletroforese em campo pulsátil (PFGE) - Amostras Sequenciais}

Recentemente, técnicas genotípicas ou moleculares tem recebido uma maior atenção como uma ferramenta para análise epidemiológica de infecções nosocomiais e para estabelecimento de inter-relação entre espécies. De modo geral, a eletroforese em campo pulsátil (PFGE) é um dos métodos de tipagem de boa reprodutibilidade e poder discriminatório e, frequentemente, é o método de escolha para muitas avaliações epidemiológicas (SINGH et al., 2006).

Neste nosso estudo utilizamos a técnica de PFGE para verificar a diversidade genotípica de 24 amostras de Candida spp provenientes de nove pacientes e que tiveram isolamentos sequenciais no sangue. Como ilustrado na Tabela 07, algumas espécies apesar de serem taxonomicamente diferentes, tiveram o mesmo perfil genotípico. Essas amostras serão avaliadas com maior acuidade tanto bioquimicamente como genotipicamente. No entanto, quando analisamos o perfil molecular das amostras isoladas do mesmo paciente, observamos que a maioria apresentou o mesmo cariótipo, sugerindo que essas amostras foram oriundas da mesma fonte de infecção e que foram novamente isoladas por falha na terapêutica ou por tempo ainda curto no tratamento.

Saracli et al. (2004) fizeram um estudo para investigar a relação genética de 3 isolados de C. albicans em 2 pacientes, através do PFGE. As 3 amostras de C. albicans de mesmo paciente, foram isoladas do sangue, abscesso e fluido de drenagem e apresentaram o mesmo cariótipo, enquanto que as 3 amostras isoladas de fluido cerebroespinhal, material nasofaríngeo e de excreção do outro paciente estavam intimamente relacionadas. Com estes resultados os autores concluíram que o PFGE foi capaz de fornecer informações sobre a fonte de transmissão nesses dois casos de infecção. A cariotipagem pelo PFGE pode indicar a possibilidade de uma infecção cruzada, principalmente por $C$. parapsilosis, que pode ser transmitida pelas mãos do pessoal que trabalha no hospital, causando a fungemia (POSTERARO et al., 2004).

Neste estudo as espécies, C. parapsilosis, C. albicans e C. tropicalis apresentaram 4,3 e 2 cariótipos diferentes, respectivamente. Estudos recentes, relatam isolados de $C$. 
parapsilosis como sendo fisiologicamente indistinguíveis mas geneticamente heterogêneos (LASKER et al., 2006). Investigações tem sugerido que esta espécie é formada por um complexo de três grupos geneticamente distintos, sendo estes conhecidos como C. parapsilosis (grupo I), C. orthopsilosis (grupo II) e C. metapsilosis (grupo III) (TAVANTI et al., 2005). Esta divisão em grupos esta baseada em técnicas moleculares como RAPD (LEHMANN et al., 1992), sequenciamento da região ITS (LIN et al., 1995), relação entre DNA (ROY et al., 1998), morfotipagem (CASSONE et al., 1995), diferenças na sequência do DNA mitocondrial (NOSEK et al., 2002), sequência do gene topoisomerase II (KATO et al., 2001) e técnicas de sondas de oligonucleotídeos (ENGER et al., 2001).

A técnica de PFGE permite a separação de moléculas grandes de DNA, incluindo os cromossomos, e estes podem variar nas espécies e entre a espécies, no tamanho e no número, sendo assim caracterizados por um determinado perfil ou cariótipo. O PFGE mostra-se muito útil para o acompanhamento de amostras isoladas de um mesmo paciente durante o curso de uma infecção, podendo-se ainda acompanhar a eficácia terapêutica.

Shin et al. (2001) diferenciaram isolados de 17 pacientes através da cariotipagem eletroforética em campo pulsado, e esta foi capaz de diferenciar vários isolados do mesmo paciente. Desses 17 pacientes foram analisados 48 isolados e 25 cariótipos diferentes foram obtidos, sendo que, cada isolado foi único para cada paciente. Este estudo mostrou uma variabilidade cromossomal de C. parapsilois isoladas de sangue, confirmando, desta forma, que não foi encontrado um perfil predominante para os isolados desta espécie durante o período de estudo.

Em nosso estudo C. parapsilosis foi a espécie mais isolada entre os pacientes que tinham leveduras com isolamentos sequenciais, mostrando 4 perfis diferentes (Tabela 7). Saracli et al. (2005) estudaram 42 amostras de C. albicans, isoladas de pacientes com fungemia e genotipadas pelo PFGE. Os resultados mostraram 31 cariótipos diferentes entre a população estudada, sendo que as amostras não estavam relacionadas entre si. Chen et al. (2005) estudaram 18 hospitais em Taiwan, com o intuito de se investigar o perfil genético de 53 cepas de $C$. albicans isoladas de pacientes HIV. Os autores demonstraram que o PFGE foi capaz de identificar isolados de "clones" relacionados do mesmo paciente. Entretanto esta técnica mostrou baixo poder discriminatório (19 
genótipos) quando comparado com o PFGE utilizando-se enzimas de restrição BssHII (40 genótipos) e SfiI (35 genótipos). Estudo realizado por Shin et al. (2005) também mostrou que a cariotipagem eletroforética é um método que tem valor limitado em termos de capacidade de diferenciação entre isolados de C. albicans, especialmente, quando comparada com a técnica que envolve a utilização de enzimas de restrição (REAG "Restriction endonuclease analysis of genomic DNA").

Nos pacientes que foram isoladas as mesmas espécies em amostras consecutivas de sangue, porém, com cariótipos diferentes, sugere-se que sejam PFGE tipos da mesma espécie ou re-infecção.

A cariotipagem pelo PFGE tem sido definida como de grande valor para estudos epidemiológicos de isolados seriados de um mesmo paciente durante um determinado período de tempo (BRANCHINI et al., 1995). Neste trabalho, a técnica se mostrou satisfatória, porém faz-se necessário outros estudos moleculares destas cepas para uma melhor discriminação das mesmas.

\subsubsection{Comparação entre as Técnicas de Microssatélites e Cariotipagem Aplicadas as} Amostras de $C$. albicans e $C$. parapsilosis

A tipagem molecular é uma técnica que fornece importantes informações sobre a distribuição e associação dos isolados entre si (TAYLOR et al., 1999). Dentre os inúmeros métodos moleculares de tipagem que vêm sendo empregadas, a análise de microssatélite e o PFGE, apresentam destaque no cenário atual (ELOY et al., 2006).

Neste estudo, realizamos uma comparação entre ambas as técnicas em relação ao poder de discriminar genotipicamente as 17 amostras de C. albicans e e as 29 amostras de C. parapsilosis. Assim, observamos que a técnica de microssatéllites demonstrou uma maior capacidade em distinguir molecularmente os isolados de Candida ,com maior poder discriminatório (0,95 e 0,84 para C. albicans e C. parapsilosis, respectivamente).

Este fato ocorreu porque a técnica de microssatélite análisa fragmentos de DNA do tipo "primer"- específico, com leitura dos dados em aparelho de sequenciador automatizado, o que contribui para o aumento do poder discriminatório e da reprodutibilidade do método. 
A técnica de PFGE mostrou menor poder discriminatório $(0,90$ e 0,62 para $C$. albicans e C. parapsilosis, respectivamente) quando comparada ao método de microssatélites. Isto deve-se ao fato também da técnica analisar todo o genoma da amostra em busca de diferenças moleculares. Além disso, os resultados do PFGE foram analisados visualmente, o que os torna menos precisos, e, consequentemente, a técnica torna-se menos reprodutível.

Para a realização da técnica de microssatélites, utilizamos para distinguir molecularmente isolados de C. albicans e C. parapsilosis, cinco (CEF3, ERK1, CDC3, $E F 3, E R K 1)$ e três $(A, B$ e $D)$ "primers", respectivamente.

Em relação as 17 amostras de C. albicans estudadas, observamos um maior poder discriminatório para o "primer" $C D C 3(0,86)$, conseguindo discriminar de forma satisfatória os isolados. Com este marcador foram observados seis perfis genotípicos diferentes, sendo os mais frequentes $127-127 \mathrm{pb}$ e $123-127 \mathrm{pb}$.

Em trabalho realizado por Botterel et al. (2001), foram utilizados os marcadores $C D C 3, E F 3$ e HIS3. O “primer' CDC3 mostrou-se com poder discriminatório de 0,77 e foi capaz de distinguir 10 perfis genotípicos entre 100 isolados de C. albicans provenientes de materiais clínicos diversos.

Esta técnica vem sendo, também, utilizada em cepas provenientes de infecção hospitalar, com o intuito de verificar o perfil genotípico de cepas e tentar estabelecer a fonte da infecção.

Eloy et al. (2006) analisaram o perfil molecular, pelo método de microssatélites, de isolados de C. albicans provenientes de infecção nosocomial. Os marcadores utilizados foram o $C D C 3, E F 3$ e HIS3. Os autores encontraram 26 genótipos diferentes em 36 isolados, sugerindo que as infecções nosocomiais poderiam ser ocasionadas por leveduras albergadas no próprio paciente.

Beretta et al. (2006), utilizando os mesmos marcadores, tinham como objetivo verifcar o perfil genotípico de isolados de C. albicans provenientes de pacientes internados em Unidade de Terapia Intensiva (UTI). Os autores observaram que todos os pacientes encontravam-se colonizados com isolados de genótipos diferentes, sugerindo que não ocorreu infecção cruzada nesses pacientes. Com relação ao método empregado, 
os autores observaram que o mesmo mostrou-se estável, reprodutível e com alto poder discriminatório $(0,97)$.

Outros marcadores também têm sido citados na literatura. Sampaio et al. (2005) utilizaram os "primers" CAI, CAII, CAV, CAVI e CAVII em 72 amostras de C. albicans. Os autores encontraram 46 genótipos diferentes e um poder discriminatório de 0,97.

Este sistema para observação de perfis moleculares pode também ser desenvolvido para tipar outras leveduras de importância médica tais como C. glabrata e C. parapsilosis.

Em nosso estudo, utilizamos três "primers" $(A, B$ e $D)$ para observar a diversidade genética de 29 isolados de $C$. parapsilosis. O marcador $A$ apresentou o maior poder discriminatório $(0,67)$, sendo observados 7 perfis genotípicos diferentes com maior frequência para o genótipo 109-109pb.

Lasker et al. (2006) utilizaram a técnica de microssatélites para distinguir genótipos de isolados de $C$. parapsilosis provenientes de casos de infecção nosocomial. Os marcadores $A$ e $B$ apresentaram o maior poder discriminatório, 0,83 e 0,87, respectivamente, sendo que o "primer" $A$ forneceu 6 genótipos diferentes com maior frequência para 109-109 pb, assim como em nosso estudo.

Em nossa pesquisa, quando combinamos todos os "primers", a técnica de microssatélite mostrou alto poder discriminatório de 0,95 e 0,84 para os isolados de $C$. albicans e C. parapsilosis, respectivamente. Desta forma, os resultados mostraram que esta técnica conseguiu discriminar de maneira satisfatória os isolados dentro das espécies estudadas.

Botterel et al. (2001) observaram um poder discriminatório referente a técnica de microssatélites de 0,97, para distinguir entre amostras de C. albicans. Lasker et al. (2006), estudando amostras de C. parapsilosis, observou um poder discriminatório para a técnica de 0,97 .

Neste estudo, segundo nossa classificação, com relação a técnica de PFGE, para os isolados de C. albicans, obtivemos nove genótipos sendo que o cariótipo E (cinco bandas - de 825 a $1600 \mathrm{pb}$ ) foi o mais frequente. Para C. parapsilosis obtivemos também nove cariótipos sendo o mais frequente o N (cinco bandas- de 825 a 2200 pb). 
Shin et al. (2001) estudaram 48 isolados de $C$. parapsilosis pela técnica de PFGE e encontraram 25 cariótipos diferentes. Saracli et al. (2005) estudando o perfil genético de 42 amostras de $C$. albicans por esta técnica obtiveram 31 diferentes cariótipos. A classificação dos cariótipos varia de autor para autor, fato que dificulta a comparação dos resultados.

Analisando as vantagens e desvantagens das técnicas, em relação a de microssatélites, constatamos que esta é uma metodologia que apresenta um custo elevado, devido a utilização de "primers" fluorescentes e aparelho sequenciador. No entanto, é uma técnica de fácil execução, rápida e, como exposto, demonstra um melhor poder discriminatório. A técnica de PFGE, também utiliza automação, com um custo operacional menor, entretanto, o tempo de realização do experimento é consideravelmente maior, apresentando menor poder discriminatório.

Nesta pesquisa comparamos os perfis genotípicos obtidos e analisamos a concordância das amostras entre as duas metodologias utizadas (PFGE e microssatélites), ou seja, a similaridade entre as amostras em ambas as metodologias. Nossos resultados mostraram que houve pouco consenso na similaridade entre as amostras nas técnicas de PFGE e microssatélites. Isto sugere que o emprego de metodologias diferentes pode diversificar o grau de similaridade molecular entre os isolados em estudo.

Nesta pesquisa, de um modo geral, o emprego destas metodologias de tipagem molecular mostrou diferenças genotípicas entre os isolados estudados, porém ressaltamos que quando comparamos esses resultados da tipagem molecular com o perfil de sensibilidade aos atifúngicos ("Etest”) o mesmo não mostrou diferenças nas CIMs $(\mu \mathrm{g} / \mathrm{mL})$ entre os isolados.

A importância do estudo da diversidade genética de isolados da mesma espécie, além da tipagem, pode estar relacionada ao tratamento terapêutico a ser escolhido, uma vez que diferentes sítios de ação aos antifúngicos podem ser expostos. Nestes subtipos, antígenos diversos também podem constituir parte da célula fúngica e com isso teremos diferentes respostas imunológicas do hospedeiro. 
CONCLUSÕES 


\section{CONCLUSÕES}

Na identificação das 70 amostras de Candida o nível de concordância entre o método tradicional e o sistema API20C foi de $93 \%$.

* De acordo com os resultados obtidos pela técnica de PCR, nenhum isolado de $C$. dubliniensis foi identificado no estudo.

Em relação a sensibilidade antifúngica, as amostras de $C$. parapsilosis, $C$. albicans, C. tropicalis e C. glabrata apresentaram alta porcentagem de amostras sensíveis às sete drogas testadas (cetoconazol, fluconazol, itraconazol, voriconazol, 5-fluorcitosina, anfotericina-B e caspofungina). As amostras de $C$. guilliermondii apresentaram uma menor porcentagem de sensibilidade em relação ao fluconazol, 5-fluorcitosina e itraconazol. C. krusei apresentou menor sensibilidade aos antifúngicos fluconazol e itraconazol. C. tropicalis apresentou baixa sensibilidade apenas para o itraconazol, enquanto que para os demais antifúngicos esta espécie apresentou $100 \%$ de sensibilidade.

* Com relação a anfotericina $\mathrm{B}$, somente uma amostra de C. parapsilosis apresentou resistência. Todas as amostras foram sensíveis a caspofungina. 
A análise molecular pela técnica de PFGE, em amostras sequenciais de mesmo paciente, permite o acompanhamento da eficácia terapêutica, bem como, a averiguação de uma possível re-infecção.

* Nos pacientes que foram isoladas as mesmas espécies em amostras sequenciais de sangue, porém, com cariótipos diferentes, sugere-se que sejam PFGE tipos da mesma espécie ou re-infecção.

* A técnica de PFGE mostrou nove cariótipos diferentes tanto para as amostras de C. albicans $(\mathrm{n}=17)$ como para as de C. parapsilosis $(\mathrm{n}=29)$. Os cariótipos mais frequentes foram E ( 5 bandas - 1020 a 1600 pb) e o N (5 bandas - 825 a 2200 $\mathrm{pb})$.

Em relação a técnica de microssatélites para as amostras de C. albicans, o marcador $C D C 3$, apresentou o maior poder discriminatório e um total de 6 perfis genotípicos (pares de bases variando de 119 a 131 pb). Enquanto que para os isolados de C. parapsilosis, o marcador com maior poder discriminatório foi o $A$, apresentando 7 perfis de cariótipos (pares de base variando de 107 a 114 pb).

A técnica de microssatélites mostrou uma maior capacidade de discriminar molecularmente os isolados de $C$. albicans $(0,95)$ e $C$. parapsilosis $(0,84)$, em comparação ao poder discriminatório da técnica de PFGE $(0,90$ e 0,62 , respectivamente). 
* A técnica de análise de microssatélites mostrou-se de fácil execução, rápida e com bom poder discriminatório, para ambas as espécies estudadas (C. albicans e $C$. parapsilosis). 


\section{REFERÊENCIAS}

\section{BIBLIOGRÁFICAS}




\section{REFERÊNCIAS BIBLIOGRÁFICAS*}

ABI-SAID, D.; ANAISSIE, E.; UZUN, O.; ROAD, I.; PINZCOWSKI, H.; VARTIVARIAN, S. The epidemiology of hematogeneous candidiasis caused by different Candida species. Clin .Infect. Dis., v. 24, p. 1122-1128, 1997.

ABUHAMMOUR, W.; HABTE-GABER, E. Newer antifungal agents. Indian. J. Pediatr., v. 71, p. 253-259, 2004

ALVES, S.H.; MILAN, E.P.; BRANCHINI, M.L.M.; NISHIMURA, K.; FUKUSHIMA, K.; OLIVEIRA, L.O.; COSTA, J.M.; COLOMBO, A.L. First isolation of Candida dubliniensis in Rio Grande do Sul, Brazil. Diag. Microbiol. Infect. Dis., v. 39, p.165-168, 2001.

ANTUNES, A.G.V.; PASQUALATO, A.C.; DIAZ, M.C.; D'AZEVEDO, P.A.; SEVERO, L.C. Candidemia in a Brazilian tertiary care hospital: species distribution and antifungal susceptibility patterns. Rev. Inst. Trop. S. Paulo, v. 46, p. 239-241, 2004.

ARAUJO, M.R.E.; COLOMBO, A.L. Infecções fúngicas hospitalares. In: Manual de Microbiologia Clínica Aplicada ao Controle de Infecção Hospitalar APECIH, p.36-40, 1998.

ARIKAN, S.; GÜR, D.; AKOVA, M. Comparison of Etest, microdilution and colorimetric dilution with reference broth macrodilution method for antifungal susceptibility testing of clinically significant Candida species isolated from immunocompromissed patients. Mycoses, v. 40, v. 291-296, 1997.

BALL, L.M.; BES, M.A.; THEELEN, B.; BOEKOUT, T.; EGELER, R.M.; KUIJPER, E.J. Significance of amplified fragment length polymorphism in identification and epidemiological examination of Candida species colonization in cildren undergoing allogenic stem cell traspaltation. J. Clin. Microbiol., v. 42, p. 1673-1679, 2004.

BAUTERS, T.G.; NELIS, H.J. Comparison of chromogenic and fluorogenic membrane filtration methods for detection of four Candida species. J. Clin. Microbiol., v. 40, p. 1838-1839, 2002.

BARCHIESI, F. et al. Transmission of fluconazole-resistant Candida albicans btween patients with Aids and oropharyngeal candidiasis documented by pulsed-field gel eletrophoresis. Clin. Infect. Dis., v. 21, p. 561-564, 1995.

\footnotetext{
* De acordo com:

ASSOCIAÇÃO BRASILEIRA DE NORMAS TÉCNICAS NRB 6023: informação e documentação: referências: elaboração. Rio de Janeiro, 2002.
} 
BERETTA, S.; FULGENCIO, J.P.; ENACHE-ANGOULVANT, A.; BERNARD, C.; METAOUA, S.; ANCELlE, T.; DENIS, M.; HENNEQUIN, C. Application of microsatellite typing for the investigation of a cluster of cases of Candida albicans candidemia. Clin. Microbiol. Infect., v. 12, p. 674-676, 2006.

BONASSOLI, L.A.; SVIDZINSKI, T.I.E. Influence of the hospital environment on yeast colonization in nursing students. Med. Mycol., v. 40, p. 311-313, 2002.

BOTTEREL, F.; CESTERKE, C.; COSTA, C.; BRETAGNE, S. Analusis of microsatellite markers of Candida albicans used for rapid typing. J. Clin. Microbiol., v. 39, p. 4076-4081, 2001.

BOYLE, B. M.; SULLIVAN, D.J.; FORKIN, C.; MULCAHY, F.; KEANE, C.T.; COLEMAN, D.C. Candida dubliniensis candidaemia in an HIV-positive patient in Ireland. Int. J. STD AIDS. v. 13, p. 55-57, 2002.

BRANCHINI, M.L.; PFALLER, M.A.; RHINE-CHALBERG, J.; FREMPONG, T.; ISENBERG, H.D. Genotypic variation and slime production among blood and catheter isolates of Candida parapsilosis. J. Clin. Microbiol., v. 32, p. 452-456, 1994.

BRANCHINI, M.L.M.; GEIGER, D.C.P.; FISCHMAN, O.; PIGNATARI, A.C. Molecular typing of Candida albicans strains isolated from nosocomial candidemia. Rev. Inst. Med. Trop. São Paulo, v. 37, p. 483-487, 1995.

BRANDT, M.E.; HARRISON, L.H.; PASS, M.; SOFAIR, A.N.; HUIE, S.; LI, R.; MORRISON, C.J.; WARNOCK, D.W.; HAJJEH, R.A. Candida dubliniensis fungemia: the first four case in North America. Emerg. Infect. Dis., v. 6, p. 46-49, 2000 .

BRETAGNE, S.; COSTA, J.M.; BESMOND, C.; CARSIQUE, R.; CALDERONE, R. Microsatellite polymorphism in the promoter sequence of the elongationfactor 3 gene of Candida albicans as the basis for a typing system. J. Clin. Microbiol., v. 35, p. 1777-1780, 1997.

BUESCHING, W.J.; KUREK, K.; ROBERTS, G.D. Evaluation of modified API 20C system for identification of clinically important yeasts. J. Clin. Microbiol., v. 9, p. 565-569, 1979.

CAGGIANO, G.; IATTA, R.; HOLMES, A.D.; MANCA, F.; MONTAGNA, M.T. observacional study on cadidaemia at a university hospital in southern Italy from 1998 to 2004. Mycoses, v. 51, p. 123-128, 2008.

CAMPBELL, C.K.; DAVEY, K.G.; HOLMES, A.D.; SZEKELY, A.; WARNOCK, D.W. Comparison of the API Candida system with the AUXACOLOR system for identification of common yeast pathogens. J. Clin. Microbiol., v. 37, p. 821-823, 1999. 
CANTON, E. et al. Patterns of amphotericin B killing kinetics aganist seven Candida species. Antimicrob. Agents Chemother., v. 48, p. 2477-2482, 2004.

CASSONE, A,; DE BERNARDIS, F.; PONTIERI, E.; CARRUBA, G.; GIRMENIA, C.; MARTINO, P.; FÉRNADEZ-RODRÍGUES, M.; QUINDÓS, G.; PONTÓN, J. Byotipe diversity of Candida parapsilosis and its relationship to the clinical source and experimental pathogenicity. J. Infect. Dis., v. 171, p. 967-975, 1995.

CHAVASCO, J.K.; PAULA, C.R.; HIRATA, M.H.; ALEVA, N.A.; MELO, C.E.; GAMBALE, W.; RUIZ, L.S.; FRANCO, M.C. Molecular identification of Candida dubliniensis isolated from oral lesions of HIV-positive and HIV-negative patients in São Paulo, Brazil. Rev. Inst. Med. Trop. São Paulo., v. 48, p. 21-26, 2006.

CHEN, Y.C.; EISNER, D.J.; KATTAR, M.M. Identification of medically important yeasts using PCR-based detectio of DNA sequence polymorphisms in the internal transcribed spacer 2 region of the rRNA ges. J. Clin. Microbiol., v. 6, p. 2302-2310, 2000 .

CHEN, K.W.; LO, H.J.; LIN, Y.H.; LI, S.Y. Comparison of four molecular typing mrthods to assess genetic relatedness of Candida albicans clinical isolates in Taiwan. J. Med. Microbiol., v. 54, p. 249-258, 2005.

CHRYSSANTHOU, E.; GRONFORS, C.; KHANNA, N. Comparison of broth macrodilution, broth microdilution and $\mathrm{E}$ test susceptibility tests of Cryptococcus neoformans for fluconazole. Mycoses, v. 40, p. 423-427, 1997.

CIMOLAI, N.; DAVIS, J.; TROMBLEY, C. Candida dubliniensis fungemia and vascular access infection. J. Pediatr. Hematol. Oncol., v. 24, p. 237-239, 2002.

CLANCY, C.J.; NGUYEN, M.H.; Comparison of a photometric method with standardized methods of antifungal susceptibility testing of yeasts. J. Clin. Microbiol., v. 35, p. 2878-2882, 1997.

CLEMONS, K.V.; FEROZE, F.; HOLMBERG, K.; STEVENS, D.A. Comparative analysis of genetic variability among Candida albicans isolates from different geographic locales by three genotypic methods. J. Clin. Microbiol., v. 35, p. 13321336, 1997.

CLSI - CLINICAL AND LABORATORY STANDARDS INSTITUTE. Reference method for broth dilution antifungal susceptibility testing for yeasts; Approved standard M27-A. Wayne, Pa. 1997. (Document M27-A).

CLSI - CLINICAL AND LABORATORY STANDARDS INSTITUTE. Reference method for broth dilution antifungal susceptibility testing for yeasts; Approved standard. Wayne, Pa. 2002. (Document M27-A2).

CLSI - CLINICAL AND LABORATORY STANDARDS INSTITUTE. Quality Control Minimal Inhibitory Concentration (MIC) Limit for Broth Microdilution 
and MIC Interpretative Breakpoints. Informacional supplement - Second Edition M27-S2. Wayne, Pa. 2005.

COLEMAN, D.C.; SULLIVAN D.J.; BENNETT, D.E. Candidiasis: the emergence of a novel species Candida dubliniensis.AIDS, v. 11, p. 557-567, 1997a.

COLEMAN, D.C.; SULlIVAN, D.J.; HAYNES,K. Molecular and phenotypic analysis of Candida dubliniensis: a recently identified species linked with orla candidosis in HIV-infected and AIDS patients. Oral Dis., v. 3, p. 96-101, 1997b. Suppl.1

COLEMAN, D.C.; RINALDI, M.G.; HAYNES, K.A.; REX, J.H.; SUMMERBELL, R.C.; ANAISSE, E.J.; LI, A.; SULLIVAN, D.J. Importance of Candida species other than Candida albicans as opportunistic pathogens. Med. Mycol., v. 36, p. 156-165, 1998. Suppl.1

COLOMBO, A.L; BARCHIESI, F.; MCGOUGH, D.A.; FOTERGILL, A.W.; RINALDI, M.G. Evaluation of Etest system versus a microtire broth for method for antifungal susceptibility of yeasts again fluconazole and itraconazole. J. Antimicrob. Chemother., v. 36, p. 93-100, 1995.

COLOMBO, A.L.; BARCHIESI, F.; MCGOUGH, D.A.; RINALDI, M.G. Comparison of $\mathrm{E}$ test and National Committee for clinical laboratory standards broth macrodilution method for azole antifungal susceptibility testing. J. Clin. Microbiol., v. 33, p. 535-540, 1995a.

COLOMBO, A.L.; BARCHIESI, F.; MCGOUGH, D.A.; FOTERGILL, A.W.; RINALDI, M.G. Evaluation of Etest system versus a microtire broth for method for antifungal susceptibility of yeasts again fluconazole and itraconzole. J. Antimicrob. Chemother., v. 36, p. 93-100, 1995b

COLOMBO, A.L.; NUCCI, M.; SALOMÃO, R.; BRANCHINI, M.L.M.; RICHTMANN, R.; DEROSSI, A.; WEY, S.B. High rate of non-albicans candidemia in Brazilian tertiary care hospitals. Diagn. Microbiol. Infect. Dis., v. 34, p. 281-286, 1999.

COLOMBO, A.L. e GUIMARÃES, T. Epidemiologia das infecções hematogênicas por Candida sp. Rev. Soc. Bras. Med. Trop., v. 36, p. 599-607, 2003.

COLOMBO, A.L.; PERFECT, J.; DINUBILE, M.; BARTIZAL, K.; MOTYL, M.; HICKS, P.; LUPINACCI, R.; SABLE, C.; KARTSONIS, N. Global distribution and outcomes for Candida species causing invasive candidiasis: results from an international randomized double-blind study of caspofungin versus amphotericin B for the treatment of invasive candidiasis. Eur. J. Clin. Microbiol. Infect. Dis., v. 22, p. 470-474, 2003.

CORMICAN, M.G e PFALLER, M.A. Standardization of antifungal susceptibility testing. J. Antimicrobiol. Chemother., v. 38, p. 561-578, 1996. 
DALLE, F.; FRANCO, N.; LOPEZ, J.; VAGNER, O. et al. Comparative genotyping of Candida as bloodstream and nonbloodstream isolates at a polymorphic microsatellite locus. J. Clin. Microbiol., v. 38, p. 4554-4559, 2000.

DAVEY, K.G.; CHANT, P.M.; DOWNER, C.S.; CAMPBELL, C.K.; WARNOCK, D.W. Evaluation of the Auxacolor System a new method of clinical yeast identification. J. Clin. Pathol., v. 48, p. 807-809, 1995.

DAVEY, K.G.; HOLMES, A.D.; JOHNSON. E.M.; SZEKELY, A.; WARNOCK, D.W. Comparative evaluation of FUNGITEST and broth microdilution methods for antifungal drug susceptibilty testing of Candida species and Cryptococcus neoformans. J. Clin. Microbiol., v. 36, p. 926-930, 1998a

DAVEY, K.G.; SZEKELY, A.; JOHNSON. E.M.; WARNOCK, D.W. Comparison of a new commercial colorimetric microdilution method with a standard method for invitro susceptibility testing of Candida spp and Cryptococcus neoformans. J. Antimicrob. Chemother., v. 42, p. 439-444, 1998 b.

DIAZ-GUERRA, T.M.; MARTINEZ-SUAREZ, J.V.; LAGUNA, F.; VALENCIA, E; RODRIGUEZ-TUDELA, J.L. Change in fluconazole susceptibility testing of Candida albicans isolated. AIDS, v. 12, p. 1601-1610, 1998.

DIEKEMA, D.J.; PFALLER, M.A.; JONES, R.N. Age-related trends in pathogen frequency and antimicrobial susceptibility of bloodstream isolates in North America. SENTRY Antimicrobial Surveilance Program, 1997-2000. Int. J. Antimicrob. Agents, v. 20, p. 412-418, 2002.

DICK, J.D.; ROSENGARD, R.R.; MERZ, W.G.; STUART, R.K.; HUTCHINS, G.M.; SAVAL, R. Fatal disseminated candidiasis due to amphotericin B-resistant Candida guilliermondii. Ann. Int. Med., v. 102, p. 67-68, 1985.

DIDOMENICO, B.J.; BROWN, N.H.; LUPISELLA, J.; GREENE, J.R.; YANKO, M.; KOLTIN, Y. Homologs of the yeasts neck filament associated genes: isolation and sequence analysis of Candida albicans CDC3 and CDC10. Mol. Gen. Genet. v. 242, p. 689-698, 1994.

DROMER, F.; IMPROVISE, L.; DUPONT, D.; ELIASZEWICS, M.; PIALOUX, G.; FOURNIER, S.; FEUILLIE, V. Oral transmission of Candida albicans between partners in HIV- infected couples could contribute to dissemination of fluconzoleresistant isolates. AIDS, v. 11, p. 1905-1101, 1997.

ENGER, L.; JOLY, S.; PUJOL, C.; SIMONSON, P.; PFALLER, M.; SOLL, D.R. Cloning and characterization of a complex DNA fingerprinting probe for Candida parapsilosis. J. Clin. Microbiol., v. 39, p. 658-669, 2001.

ELOY, O.; MARQUE, S.; BOTTEREL, F.; STEPHAN, F.; COSTA J.M.; LASSERRE, V.; BRETAGNE, S. Uniform distribution of three Candida albicans 
microsatellite marker in two French ICU population supports a lack os nosocomial cross-contamination. BMC Infect. Dis., v. 13, p. 156-162, 2006.

EL-ZAATARI, M.; PASARELL, L.; MCGINNIS, M.R.; BUCKNER, J.; LAND, G.A.; SALKIN, I.F. Evaluation of the updated Vitek yeast identification data base. J. Clin. Microbiol., v. 29, p. 1938-1941, 1990.

ESPINEL-INGROFF, A.; PFALLER, M.; ERWIN, M.E.; JONES, R.N. Interlaboratory evaluation of Etest method for testing antifungal susceptibilities of pathogenic yeasts to five antifungal agents by using Casitone agar and solidified RPMI 1640 medium with 2\% glucose. J. Clin. Microbiol., v. 34, p. 848-852, 1996.

ESPINEL-INGROFF, A.; STOCKMAN, L.; PINCUS, D.; POLLACK, J.; MARLER, J. Comparison of rapID Yeast Plus System with API 20C System for identification of common, new, and emerging yeast pathogens. J. Clin. Microbiol., v. 36, p. 883-886, 1998.

ESPINEL-INGROFF, A.; VAZQUEZ, J.A.; BOIKOV, D.; PFALLER, M.A. Evaluation of DNA-based typing procedures for strain categorization of Candida spp. Diagn. Microbiol. Infect. Dis., v. 33, p. 231-239, 1999.

ESPINEL-INGROFF, A.; BOYLE, K.; SHEEHAN, D. In vitro antifungal activities of voriconazole and reference agents as determined by NCCLS methods. Review of the literature. Mycopathologia, v. 150, p. 101-115, 2001.

FAVEL, A.; PEYRON, F.; DEMEO, M.; MICHEL-NGUYEN, A.; CARRIEU, J.; CHASTIN, C.; REGLI, P. Amphotericin B susceptibility testing of Candida lusitaniae isolates by flow cytofluorometry: comparison with the Etest and the NCCLS broth macrodilution method. J. Antimicrob, Chemother., v. 43, p. 227-232, 1999.

FENN, J.P.; SEGAL, H.; BARLAND, B.; DENTON, D.; WHISENANT, J.; CHUN, H.; CHRISTOFFERSON, K.; HAMILTON, L.; CARROLL, K. Comparison of update Vitek yeast biochemical card and API 20C yeast identidication system. J. Clin. Microbiol., v. 32, p. 1184-1187, 1994.

FRICKER-HIDALGO, H.; VANDAPEL, O.; DUCHESNE, M.A.; MAZOYER, M.A.; MONGET, D.; LARDY, B.; LEBEAU, B.; FRENEY, J.; THOMASAMBROISE, P.; GRILLOT, R. Comparison of the new Api Candida system to the ID 32C system for identification of clinically important yeast species. J. Clin. Microbiol., v. 34, p. 1846-1848, 1996.

FRIDKIN, S.K. \& JARVIS, W.R. Epidemiology of nosocomial fungal infections. Clin. Microbiol. Rev., v. 9, p. 499-511, 1996.

FRIDKIN, S.K.; KAUFMAN, D.; EDWARDS, J.R.; SHATTY, S.; HORAN, T. Changing incidence of Candida bloodstream infections among NICU patients in the United States. Pediatrics, v. 117, p. 1680-1687, 2006. 
FUNDYGA, R.E.; LOTT, T.J.; ARNOLD, J. Population structure od Candida albicans, a member of the human flora, as determined by microsatellite loci. Infect. Gen. Evol., v. 2, p. 57-968, 2002.

GHANNOUM, M.A. e ABU-ELTEEN, K.H. Pathogenicity determinants of Candida. Mycoses, v. 33, p. 265-282, 1990.

GHANNOUM, M.A. e RICE, L.B. Antifungal agents: mode of action, mechanisms of resistance and correlation of these mechanisms with bacterial resistance. Clin. Microbiol. Rev., v. 12, p. 501-517, 1999.

GIAMMANCO, G.M.; PIZZO, G.; PECORELLA, S.; DISTEFANO, S.; PECORARO, V.; MILICI, M.E. Identification of Candida dubliniensis among oral yeast isolates from an Italian population of human immunodeficiency virus-infected (HIV+) subjects. Oral Microbiol. Immunol., v. 17, p. 89-94, 2002.

GOLDANI, L.Z.; MARIO, P.S. Candida tropicalis fungemia in a tertiary care hospital. J. Infect., v. 46, p. 150-160, 2003.

GOTTLIEB, G.S.; LIMAYE, A.P.; CHEN, Y.C.; VAN VOORHIS, W.C. Candida dubliniensis fungemia in a solid organ transplant patient: case report and review of the literature. Med. Micol., v. 39, p. 483-485, 2001.

HAJJEH, R.A. et al. Incidence of bloodstream infections due to Candida species and in vitro susceptibilities of isolates collected from 1998 to 2000 ina apopulation-based active surveillance program. J. Clin. Microbiol., v. 42, p. 1519-1527, 2004.

HEELAN, J.S.; SOTOMAYOR, E.; COON, K.; D'AREZZO, J.B. Comparison of the rapid yeast plus panel with the API 20C yeast system for identification of clinically significant isolates of Candida species. J. Clin. Microbiol., v. 36, p. 1443-1445, 1998.

HUNTER, P.R.; GASTON, M.A. Numerical index of the discriminatory ability of typing systems an application of Simpson's index od diversity. J. Clin. Microbiol., v. 26, p. 2465-2466, 1988.

JABRA-RIZK M.A.; FALKLER J.R.W.A.; MERZ W.G.; BAQUI A.A.M.A.; KELLEY J.I.; MEILLER T.F. Retrospective identification and characterization of Candida dubliniensis isolates among Candida albicans clinical laboratory isolates from human immunodeficiency virus (HIV)-infected and non-HIV-infected individuals. J. Clin. Microbiol., v. 38, p. 2423-2426, 2000.

JABRA-RIZK, M.A.; FAKLER, Jr.; MERZ, W.A.; KELLEY, J.I.; BAQUI, A.A.M.A.; MEILLER, T.F. Coagregation of Candida dubliniensis with Fusobacterium nucleatum. J. Clin. Microbiol., v. 37, p. 1464-1468, 1999. 
JABRA-RIZK, M.A.; JOHNSON, J.K.; FORREST, G.; MANKES, K.; MEILLER, T.F.; VENEZIA, R.A. Prevalence of Candida dubliniensis fungemia at a large teaching hospital. Clin. Infect. Dis., v. 41, p. 1064-1067, 2005.

JARVIS, W.R.; EDWARDS, J.R.; CULVER, D.H.; HUGHES, J.M.; HORAN, T.; EMORI, T.G.; BANERJEE, S.; TOLSON, J.; HENDERSON, T.; GAYNES, R.P. Nosocomial infection rates in adults and pediatric intensive care units. Am. J. Med., v. 91, p. 185S-191S, 1991.

JARVIS, W.R. Epidemiology of nosocomial fungal infections, with emphasis on Candida species. Clin. Infect. Dis., v. 20, p. 1526-1530, 1995.

JARVIS, W.R. Selected aspectos of the socioeconomic impact of nosocomial infections: morbidity, mortality, cost, and prevention. Infect. Control. Hosp. Epidemiol., v. 17, p. 552-557, 1996.

JOLY, S.; PUJOL, C.; RYSZ, M.; VARHGAS, K.; SOLL, D.R. Development and characterization of complex DNA fingerprinting probes for the infectious yeasts Candida dubliniensis. J. Clin. Microbiol., v. 37, p. 1035-1044, 1999.

KANALLOUPOULOU, M.; STAMOS, G.; PETINNELLI, I.; SAVALA, M.; TZIMOGIANNI, A.; LEGAKIS, N.J.; FOUSTOUKOU, M.; PAPAFRAGAS, E.; VELEGRAKI, A. Subtyping and antifungal susceptilities of Candida spp in the intensive care unit of a Greek general hospital. Int. J. Antimicrob. Agents v.18, p. 179-183, 2001.

KATO, M.; OZEKI, M.; KIKUCHI, A.; KANBE, T. Phylogenetic relationship and mode of evolution of yeasts DNA topoisomerase II gene in the pathogenic Candida species. Gene, v. 272, p. 275-281, 2001.

KAO, A.S.; BRANDI, M.E.; PRUIT, W.R.; CONN, L.A.; PRKINS, B.A.; STEPHENS, D.S.; BAUGHMAN, W.S.; REINGOLD, A. L.; ROTHROCK, G.A.; PFALLER, M.A.; PINNER, R.W.; HAJJEH, R.A. The epidemiology of candidemia in two United States Cities: Results of a population-basead active surveillance. Clin. Infect. Dis., v. 29, p. 164-170, 1999.

KARTSONIS, N.A.; SAAH, A.; LIPKA, C.J.; TAYLOR, A.; SABLE, C.C. Secondline therapy with caspofungin for mucosal or invasive candidiasis: results from the caspofungin compassionate-use study. J. Antimicrob. Chemother., v. 53, p. 878881, 2004.

KHAN, Z.U.; AHMAD, S.; MOKADDAS, E.; CHANDY, R. Tobacco Agar, a new medium for differentiating Candida dubliniensis from Candida albicans. J. Clin. Microbiol., v. 42, p. 796-4798, 2004.

KIRKPATRICK, W.R. et al. Fluconazole disk diffusion susceptibility testing of Candida species. J. Clin. Microbiol., v. 36, p. 3429-3432, 1998. 
KOÇ, A.N.; GOKAHMETÒGLU, S.; ÒGUZKAYA, M. Comparison of Etest with the broth microdilution method in susceptibility testing of yeast isolates against four antifungals. Mycoses, v. 43, p. 293-297, 2000.

KOSSOFF, E.H.; BUESCHER, E.S.; KARLOWICS, M.G. Candidemia in a neonatal intensive a care unit: trends during fifteen years and clinical features of 111 cases. Pediatr. Infect. Dis. J., v. 17, p. 504-508, 1998.

KOVACICOVA, G. et al. Nosocomial fungemia due to amphotericin B-resistant Candida spp in three pediatric patients after previous neurosurgery for brain tumors. J. Infect. Chemother., v. 7, p. 45-48, 2001.

KRCMERY, V.; BARNES, A.J. Non-albicans Candida spp. causing fungaemia: pathogenicity and antifungal resistance. J. Hosp. Infect., v. 50, p. 243-260, 2002.

KURZAI, O.; HEINZ, W.J.; SUlLIVAN, D.J.; COLEMAN, D.C.; FROSCH, M.; MÜHLSCHLEGEL, F.A.; Rapid PCR test for discriminating between Candida albicans and Candida dubliniensis isolates using primers derived from the $\mathrm{pH}-$ regulated PHR1 and PHR2 genes of C. albicans. J. Clin. Microbiol., v. 37, p. 15871590, 1999.

KURTZMAN, C.P.; FELL, J.W. The yeasts: a taxonomic study. Amsterdam: The Netherlands, 1998, 1055p.

LACAZ, C.S.; PORTO, E.; MARTINS, J.E.C.; HEINS VACCARI, E.M.; MELO, N.T. Tratado de Micologia Médica. 9 ed. São Paulo: Sarvier, 2002.1104p.

LAND, G.A.; HARRISON, B.A.; HULME, K.L.; COOPER, B.H.; BYRD, J.C. Evaluation of the new API 20C strip for yeast identification against a conventional method. J. Clin. Microbiol., v. 10, p. 357-364, 1979.

LASKER, B.A.; BUTLER, G.; LOTT, T.J. Molecular genotyping of Candida parapsilosis group I clinical isolates by analysis of polymorphic microdatellite markers. J. Clin. Microbiol. v. 44, p. 750-759, 2006.

LEES, E.; BARTON, R.C. The use of niger seed agar to screen for Candida dubliniensis in the clinical microbiology laboratory. Diag. Microbiol. Infect. Dis., v. 46, p. 13-17, 2003.

LEHMANN, P.F.; LIN, D.; LASKER, B.A. Genotypic identification and characterization of species and strains within the genus Candida by using random amplified polymorphic DNA. J. Clin. Microbiol., v. 30, p. 3249-3254, 1992.

LETSCHER-BRU, V.; MEYER, M.H.; GALOISY, A.C.; WALLER, J.; CANDOLFI, E. Prospective evaluation of the new chromogenic medium Candida ID, in comparison with Candiselect, for isolation of molds and isolation and presumptive identification of yeast species. J. Clin. Microbiol., v. 40, p. 1508-1510, 2002. 
LEVIN, A.S.; COSTA, F.S.; MUSSI, N.S.; BASSO, M.; SINTO, S.I.; MACHADO, C.; GEIGER, D.C.; VILLARES, M.C.; SCHREIBER, A.Z.; BARONE, M.; BRANCHINI, M.L. Candida parapsilosis fungemia associated with implantable and semi-implantable central venous catheters and the hands of health care workers. Diagn. Microbiol. Infect. Dis., v. 30, p. 243-249, 1998.

LEVY, I.; RUBIN, L.G.; VASISHTHA, S.; TUCCI, V.; SOOD, S.K. Emergence of Candida parapsilosis as the predominant species causing candidemia in children. Clin. Infect. Dis., v. 26, p. 1086-1088, 1998.

LIN, C.C.S. e FANG, D.Y.C. Conventional and rapid methods for yeast identification. Crit. Rev. Microbiol., v. 14, p. 273-288, 1987.

LIN, D.; WU, L.C.; RINALDI, M.G.; LEHMANN, P.F. Three distinct genotypes within Candida parapsilosis from clinical sources. J. Clin. Microbiol., v. 33, p. 1815-1821, 1995.

LOSANO-CHIU, M.J.; PAIETZNICK, V.L.; GHANNOUM, M.A.; REX, J.H. Detection of resistance to amphotericin B among Crypococcus neoformans clinical isolates: performances of three differents media assessed by using Etest and National Committee for Clinical Laboratory Standards M-27A methodologies. J. Clin. Microbiol., v. 36, p. 2817-2822, 1998.

LOTT, T.J.; FUNDYGA, R.E.; BRANDT, M.E.; HARRISON, L.H.; SOFAIR, A.N.; HAJJED, R.A.; WARNOCK, D.W. Stability of allelic frequencies and distribuitions of Candida albicans microsatellite loci from U.S, population-based surveillence isolates. J. Clin. Microbiol., v. 41, p. 1316-1321, 2003.

LUNEL, F.V.; LICCIARDELLO, L.; STEFANI, S. Et al. Lack of consistent short sequence repeat polymorphisms in genetically homologous colonizing and invasive Candida albicans strains. J. Bacteriol., v. 180, p. 3771-3778, 1998.

MADSEN, K.M.; ARENDRUP, M.C.; HASLET, L.; KNUDSEN, J.D. Amphotericin $\mathrm{B}$ and caspofungin resistance in Candida glabrata isolates recovered from a critically ill patient. Clin. Infect. Dis., v. 42, p. 938-944, 2006.

MAGEE, B.B.; KOLTIN, J.A.; MAGEE, P.T. Assignment of cloned genes to the seven eletrophoretically separated Candida albicans chromosomes. Mol. Cell. Biol. v. 8, p. 4721-4726, 1988.

MANNARELLI, B.M. e KURTZMAN, C.P. Rapid identification of Candida albicans and other human pathogenic yeasts by using short oligonucleotidess in a PCR. J. Clin. Microbiol., v. 36, p. 1634-1641, 1998.

MARIANO, P.L.S.; MILAN, E.P.; MATTA, D.A.; COLOMBO, A.L. Candida dubliniensis identification in Brazilian yeast stock collection. Mem. Inst. Oswaldo Cruz v. 98, p. 533-538, 2003. 
MAROL, S.; YÜCESOY, M. Molecular epidemiology of Candida species isolated from clinical specimens of intensive care unit patients. Mycoses, v. 51, p.40-49, 2008.

MARR, K.A.; RUSTAD, T.R.; REX, J. H.; WHITE, T.C. The trailing endpoint phenotype in antifungal susceptibility testing is $\mathrm{pH}$ dependent. Antimicrob. Agents Chemother., v. 43, p. 1383-1386, 1999.

MARRIOT, D.; LAXTON, M.; HARKNESS, J. Candida dubliniensis candidemia in Australia. Emerg. Infect. Dis., v. 7, p. 479, 2001.

MARTÍN-MAZUELOS, E.; GUTIÉRREZ, M.J.; ALLER, A.I.; MARTÍNEZ, M.A.; MONTERO, O.; QUINDÓS, G. A comparative evaluation of Etest and broth microdilution methods for fluconazole and itraconazole susceptibility testing of Candida spp. J. Antimicrob. Chemother., v. 43, p. 477-481, 1999.

MATSUMOTO, F.E.; GANDRA, R.F.; RUIZ, L.S.; AULER, M.E.; MARQUES, S.A.V.; GAMBALE, W.; PIRES, M.F.C.; PAULA, C.R. Yeasts isolated from blood and catheter in children from a Public Hospital of São Paulo, Brasil. Mycopathologia, v. 154, p. 63-69, 2001.

McMULLAN, R.; XU, J.; MOORE, J.E.; MILLAR, B.C.; WALKER, M.J.; IRWIN, S.T,; PRICE, J.; BAAR, J.; HEDDERWICK, S. Candida dubliniensis bloodstream infection in patients with gynaecological malignancy. Eur. J. Clin. Microbiol. Infect. Dis., v. 21, p. 635-636, 2002.

MEILLER T.F.; JABRA-RIZK M.A.; BAQUI A.; KELLEY J.I.; MEEKS V.I.; MERZ W.G.; FALKLER W.A. Oral Candida dubliniensis as a clinically important species in HIV-seropositive patients in the United States. Oral Surg. Oral Med. Oral Pathol. Oral Radiol. Endod. v. 88, p. 573-580, 1999.

MEIS J.F.G.M.; RUHNKE M.; PAUW B.E.D.; ODDS F.C.; SIEGERT W.; VERWEIJ P.E. Candida dubliniensis candidemia in patients with chemotherapyinduced neutropenia and bone marrow transplantation. Emerg. Infect. Dis., v. 5, p. 150-153, 1999.

METZGAR, D.; VAN BELKUM, A.; FIELD, D.; HAUBRICH, R.; WILLS, C. Random amplification of polymorphic DNA and microsatellite genotyping of pre- and posttreatment isolates of Candida sp. From human immunodificiency virus -infected patients on different fluconazole regimens. J. Clin. Microbiol., v. 36, p. 2308-2313, 1998.

MEYER, W.; MASZEWSKA, K.; SORREL, T.C. - PCR fingerprinting: a convenient molecular tool to distinguish between Candida dubliniensis and Candida albicans. Med. Mycol., v. 39, p. 185-193, 2001.

MILAN, E.P.; COLOMBO, A.L.; LAET SANT AN,; LEWI, D.S.; MELO, A.S.A. Primeiro isolamento de Candida dubliniensis no Brasil: In: CONGRESSO BRASILEIRO DE INFECTOLOGIA XI (1999), São Paulo. Resumos. 
MILAN, E.P.; SANT'ANA P.L.; MELO, A.S.A.; SULLIVAN, D.J.; COLEMAN, D.C.; LEWI, D.; COLOMBO, A.L. Multicenter prospective surveillance of oral Candida dubliniensis among adult Brazilian human immunodifieciency virus-positive and AIDS patients. Diag. Microbiol. Infect. Dis., v. 41, p. 29-35, 2001.

MORA-DUARTE, J.; BETTS, R.; COLOMBO, A.L.; THOMPSON-MOVA, L.; SMIETANA, J.; LUPINACCI, R.; SABLE, C.; KARTSONIS, N.; PERFECT, J.; CASPOFUNGIN INVASIVE CANDIDIASIS STUDY GROUP Comparison of caspofungin and amphotericin B for invasive candidiasis. N. Engl. J. Med., v. 347, 2020-2029, 2002.

MORACE, G.; AMATO, G.; BISTONI, F. et al. Multicenter comparative evaluation of six system and the National Commitee for Clinical Laboratory Standards M27-A Broth Microdilution for fluconazole susceptibility testing of Candida species. J. Clin. Microbiol., v. 40, 2953-2958, 2002.

MORAN, G.P.; SULLIVAN, D.J.; HENMAN, M.C.. Antifungal drug susceptibilities of oral Candida dubliniensis isolates from human immunodeficiency virus (HIV) infected and non-HIV-infected subjects and generation of stable fluconazole-resistant derivatives in vitro. Antimicrob. Agents Chemother., v. 41, 617-623, 1997.

MUBAREKA, S.; VINH, D.C.; SANCHE, S.E. Candida dubliniensis bloodstream infection: a fatal case in a lung transplant recipient. Transpl. Infect. Dis., v. 7, p. $146-149,2005$

MYERS, K.K.; FONZI, W.A.; SYPHERD, P.S. Isolation and sequence analysis of the gene for translation and elongation factor 3 from Candida albicasn. Nucleic Acids Rev., v. 20, p. 1705-1710, 1992.

NG, K.P.; MADASAMY, M.; SAW, T.L.; BAKI, A.; HE, J,; SOO-HOO, T.S. Candida biotypes isolated from clinical specimens in Malaysia. Mycopathologia, v. 144, p. 135-140, 1999.

NG, K.P.; SAW, T.L.; NA, S.L.; SOO-HOO, T.S. Systemic Candida infection in University Hospital 1997-1999: the distribution of Candida biotypes and antifungal susceptibility patterns. Mycopathologia, v. 149, p. 141-146, 2000.

NOSEK, J.; ADAMÍKOVÁ, L.; ZEMANOVÁ, J.; TOMÁSKA, L.; ZUFFEREY, R.; MAMOUN, C.B. Genetic manipulation of the pathogenic yeast Candida parapsilosis. Curr. Genet., v. 42, p. 27-35, 2002.

NUCCI, M.; ANAISSE, E. Revisiting the source of candidemia: skin or gut? Clin. Infect. Dis., v. 33, p. 1959-1967, 2001.

ODDS, F.C. Candida and candidoses. 2 ed. London: Bailliére Tindall, 1998. 468p.

PAGANO, L.; ANTINORI, A.; AMASSARI, A.; MELE, L.; NOSARI, A.; MELILLO, L.; MARTINO, B.; SANGUINETI, M.; EQUITANI, F.; NOBILE, F.; 
CAROTENUTO, M.; MORRA, E.; MORACE, G.; LEONE, G. Retrospective studu of candidemia in patients with hematological malignancies, clinical features, risk factors and outcome of 76 episodes. Eur. J. Haematol., v. 63, p. 77-85, 1999.

PARK, S.; WONG, M.; MARRAS, S.A.E.; CROSS, E.W.; KIEHN, T.E.; CHATURVEDI, V.; TYAGI, S.; PERLIN, D.S. Rapid identification of Candida dubliniensis using a species-specific molecular beacon. J. Clin. Microbiol., v. 38, p. 2829-2836, 2000.

PAULA, C.R.; MATSUMOTO, F.E.; MELO, T.A. Possible catheter-related infections in a Public Children's Hospital of São Paulo, Brazil. In: ASM Conference on Candida and Candidiasis, 1999a, Charleston, South Carolina, Abstract p.35.

PELLETIER, R.; LORANGER, L.; MARCOTTE, H.; CAROLIS, E. Voriconazole and fluconazole susceptibility of Candida isolates.J. Med. Microbiol., v. 51, p. 479483, 2002.

PFALLER, M.A. \& BARRY, A.L. Evaluation of a new colorimetric broth macrodilution method for antifungal susceptibility testing of yeasts isolates. J. Clin. Microbiol., v. 32, p. 1992-1996, 1994.

PFALLER, M.A. Epidemiology of candidiasis. J. Hosp. Infect., v. 30, p. 329-338, 1995

PFALLER, M.A. Nosocomial candidiasis: emerging species, reservoirs, and modes of transmission. Clin. Infect. Dis., v. 22, p. 89-94, 1996. Suppl 2

PFALLER, M.A.; MESSER, A.S.; KARLSSON, A.; BOLMSTROM, A. Evaluation of the Etest method for determining fluconazole susceptibilities of 402 clinical yeast isolates by using three different agar media. J. Clin. Microbiol., v. 36, p. 2586-2589, 1998.

PFALLER, M.A.; JONES, R.N.; MESSER, S.A.; EDMOND, M.B.; WENZEL, R.P. National surveillance of nosocomial blood stream infections due to Candida albicans: Frequency of occurrence and antifungal susceptibility in the SCOPE program. Diagn. Microbiol. Infect. Dis., v. 31, p. 327-332, 1998a.

PFALLER, M.A.; MESSER, S.A.; BOLMSTROM, A. Evaluation of Etest for determining in vitro susceptibility of yeast isolates to amphotericin B. Diagn. Microbiol., v. 32, 223-227, 1998 b.

PFALLER, M.A.; MESSER, S.A.; KARLSSON, A.; BOLMSTROM, A. Evaluation of the Etest method for determining fluconazole susceptibilities of 402 clinical yeats isolates by using three different agar media. J. Clin. Microbiol., v. 36, p. 2586-2589, $1998 \mathrm{c}$.

PFALLER, M.A.; JONES, R.N.; DOERN, G.V. International surveillance of blood stream infections due to Candida species in the Eurpean SENTRY Program: species 
distribution and antifungal susceptibility including the investigational triazole and echinocandin agents. SENTRY Participant Group (Europe). Diagn. Microbiol. Infect. Dis., v. 35, p. 19-25, 1999.

PFALLER, M.A.; JONES, R.N.; DOERN, G.V. et al Bloodstream infections due to Candida species: SENTRY Antimicrobial Surveillance Program in North America and Latin America, 1997-1998. Antimicrob. Agents Chemother., v. 44, p. 745-751, 2000 .

PFALLER, M.A. e DIEKEMA, D.J. Role of sentinel survellance of candidemia. Trends in species distribution and antifungal susceptibility. J. Clin. Microbiol., v. 40, p. 3551-3557, 2002.

PFALLER, M.A. et al. In vitro activies of voriconazole, posaconazole, and four licensed systemic antifungal agents against Candida species infrequently isolated from blood. J. Clin. Microbiol., v. 41, p. 78-83, 2003.

PFALLER, M.A.; BOYKEN, L.; HOLLIS, R.J.; MESSER, S.A.; TENDOLKAR, S.; DIEKEMA, D.J. Global surveillance in vitro activity of micafungin against Candida: a comparison with caspofungin by CLSI-recommended methods. J. Clin. Microbiol., v. 44, p. 3533-3538, 2006.

PFALLER, M.A.; BOYKEN, L.; HOLLIS, R.J.; KROEGER, J.; MESSER, S.A.; TENDOLKAR, S.; DIEKEMA, D.J. In vitro susceptibility of invasive isolates of Candida spp. to anidulafungin, caspofungin, and micafungin: six years of global surveillance. J. Clin. Microbiol., v. 46, p. 150-156, 2008.

PINJON, E.; SULLIVAN, D.; SALKIN, I.; SHANLEY, D.; COLEMAN, D. Simple, inexpensive, reliable method for differentiation of Candida dubliniensis from Candida albicans. J. Clin. Microbiol., v. 36, p. 2093-2095, 1998.

POIKONEN, E.; VUOPIO-VARKILA, J.; KAUKORANTA-TOLVANEN, S.S.; SIVONEN, A.; SIREN, E.; RUUTU, P. Epidemiological typing of Candida albicans from bloodstream infections by restriction enzyme analysis. Scan. J. Infect. Dis., v. 33 , p. $140-144,2001$

POLACHECK, I.; STRAHILEVITZ, J.; SULLIVAN, D.; DONNELLY, S.; SALKIN, F.; COLEMAN, D.C. Recovery of Candida dubliniensis from non-human immunodeficiency virus-infected patients in Israel. J. Clin. Microbiol., v. 38, p. 170$174,2000$.

PONTON, J.; RUCHEL, R.; CLEMONS, K.V. et al. Emerging pathoges. Med. Mycol., v. 38, (Suppl.1), p. 225-236, 2000.

POSTERARO, B.; ROMANO, L.; SANGUINETTI, M.; MASUCCI, L.; MARACE, G.; FADDA, G. Commercial system for fluconazole susceptibility testing of yeast: comparison with the both microdilution method. Diag. Microbiol. Infect. Dis., v. 38, p. 29-36, 2000 . 
POSTERARO, B.; BRUNO, S.; BOCCIA, S.; RUGGIERO, A.; SANGUINETTI, M.; ROMANO SPICA, V.; RICCIARDI, G.; FADDA, G. Candida parapsilosis bloodstream infection in pediatric oncology patients: results of an epidemiologic investigation. Infect. Control Hosp. Epidemiol., v. 25, p. 641-645, 2004.

RAMANI, R.; GROMADZKI, S.; PINCUS, D.H.; SALKIN, I.F.; CHATURVEDI, V. Efficacy of API 20C and ID 32C systems for identification of common and rare clinical yesat isolates. J. Clin. Microbiol., v. 36, p. 3396-3398, 1998.

REVANKAR, S.G.; KIRKPATRICK, W.R.; McATEE, R.K.; FOTHERGILL, A.W.; REDDING, S.W.; RINALDI, M.G.; PATTERSON, T.F. Interpretation of trailing endpoints in antifungal susceptibility testing by the National Committee for Clinical Laboratory Standards method. J. Clin. Microbiol., v. 36, p. 153-156, 1998.

REX, J.H.; WALSH, T.J.; SOBEL, J.D. Practice guidelines for the treatment of candidiasis. Clin. Infect. Dis., v. 30, p. 662-678, 2000.

RICHARDS, M.J.; EDWARDS, J.R.; CULVER, D.H.; GAYNES, R.P. Nosocomial infections in medical intensive care units in the United States. National Nosocomial Infections Surveillance System. Crit. Care Med., v. 27, p. 887-892,1999.

RIEDERER, K.; FOZO, P.; KHATIB, R. Typing of Candida albicans and Candida parapsilosis species-related limitations of eletrophoretic karyotyping and restriction endonuclease analysis of genomic DNA. Mycoses, v. 41, p. 397-402, 1998.

RODRIGUEZ-TUDELA, J.L. e CUENCA-ESTRELLA, M. Fungemia by yeast: a multicenter study in Spain. Rev. Clin. Esp., v., p. 199: 356-361, 1999.

ROY, B.; MEYER, S.A. Confirmation of the distinct genotype groups within the form species Candida parapsilosis. J. Clin. Microbiol., v. 36, p. 216-218, 1998.

RUHNKE, M. SCHIMIDT-WESTHAUSEN, A.; TRAUTMANN, M. In vitro activities of voriconazole (UK-109,496) against fluconazole-susceptible and resistant Candida albicans isolates from oral cavities of patients with human immunodeficiency virus infection. Antimicrob. Agents Chemother., v. 41, p. 575577, 1997.

RUIZ, L.S.; SUGIZAKI, M.F.; MONTELLI, A.C.; MATSUMOTO, F.E.; PIRES, M.F.C.; DA SILVA, B.C.M.; SILVA, E.H.; GANDRA, R.F.; GONÇALVES DA SILVA, E.; AULER, M.E.; PAULA, C.R. Fungemia by yeasts in Brazil: ocurrance and phenotypic study of strains isolated at the Public Hospital, Botucatu, São Paulo. J. Mycol. Med., v. 15, p. 13-21, 2005.

SAFRAN, D.B.; DAWSON, E. The effect of empiric and prophylactic treatment with fluconazole on yeast isoaltes in a surgical trauma invasive care unit. Arch. Surg., v. 132, p. 1184-1188, 1997. 
SALESA, R.; MORAGUES, M.D.; SOTA, R.; PEMÁN, J.; QUINDÓS, G.; PONTÓN, J. Specific antibody response in a patient with Candida dubliniensis fungemia. Rev. Iberoam. Micol., v. 18, p. 42-44, 2001.

SALKIN, I.F.; PRUITT, W.R.; PADHYE, A.A.; SULlIVAN, D.; COLEMAN, D.; PINCUS, D.H. Distinctive carbohydrate assimilation profiles used to identify the first clinical isolates of Candida dubliniensis recovered in the United States. J. Clin. Microbiol., v. 36, p. 1467, 1998.

SAMARANAYAKE, Y.H.; SAMARANAYAKE, L.P.; DASSANAYAKE，R.S.; YAU, J.Y.; TSANG, W.K.; CHEUNG, B.P.; YEUNG, K.W. Genotypic shuffling of sequencial clones of Candida albicans in HIV-infected individuals with and without symptomatic oral candidiasis. J. Med. Microbiol., v. 52, p. 349-359, 2003.

SAMPAIO, P.; GUSMÃO, L.; ALVES, C.; PINA-VAZ, C.; AMORIM, A.; PAIS, C. Highly polymorphic microsatellite for identification of Candida albicans strains. J. Clin. Microbiol., v. 41, p. 552-557, 2003.

SANDVEN, P.; BEVANGER, L.; DIGRANES, A.; GAUSTAD, P.; HAUKLAND, H.; STEINBAKK, and the Noweigian Yeast Study Group. Constant low rate of fungemia in Norway, 1991-1996. J. Clin. Microbiol., v. 36, p. 3455-3459, 1998.

SANGLARD, D. e ODDS, F.C. Resistance of Candida species to antifungal agents: molecular mechanisms and clinical consequences. Lancet Infect. Dis., v. 2, p. 73-85, 2002.

SANO, A.; VILELA, M.M.; TAKAHASHI, I.; FUKUSHIMA, K. TAKIZAWA, K.; SILVA, MT.; UNO, J.; NISHIMURA, K.; MIYAJI, M. Isolation of Candida dubliniensis from the oral cavity of an HIV-positive child in Brazil. Nippon Ishinkin Gakkai Zasshi, v. 41, p. 177-181, 2000.

SARACLI, M.A.; YILDIRAN, S.T.; YAGCI, G.; OZDAG, F.; DOGANCI, L. Karyotipic investigation of two cases of invasive candidiasis. Mikrobiyol. Bul., v. 38, p. 449-453, 2004.

SARACLI, M.A.; YILDIRAN, S.T.; GONLUM, A.; DONANCI, L. Genotyping of Candida albicans strains isolated from nosocomial fungemia patients by pulsed-field electroforesis. Mikrobiyol. Bul., v. 39, p. 191-198, 2005.

SCHERER, S.; STEVENS, D.A. Aplication of DNA typing methods to epidemiology and taxonomy of Candida J. Clin. Microbiol., v. 25, p. 675-679, 1987.

SCHOOFS, A.; ODDS, F.C.; COLEBUNDERS, R.; IEVEN, M.; GOOSSENS, H. Use of a specialization isolation media for recognition and identification of Candida dubliniensis isolates from HIV-infected patients. Eur. J. Clin. Microbiol. Dis., v. 16, p. 296-300, 1997. 
SCHORLING, S.R.; KORTINGA, H.C.; FROSCHB, M.; MÜHLSCHLEGEL, F.A. The role of Candida dubliniensis in oral candidiasis in human immunodeficiency virus-infected individuals. Crit. Rev. Microbiol., v. 26, p. 59-68, 2000.

SCHUFFENECKER, I.; FREYDIÉRE, A.; de MONTCLOS, H.; GILLE, Y. Evaluation of four commercial systems for identification of medically important yeasts. Eur. J. Clin. Microbiol. Infect. Dis., v. 12, p. 255-260, 1993.

SEWELL, D.L; PFALLER, M.A.; BARRY, L.A. Comparison of broth macrodilution , broth microdilution and Etest antifungal susceptibility tests for fluconazole. J. Clin. Microbiology, v. 32, p. 2099-2102, 1994.

SHEEHAN, D.J.; HITCHCOCK, C.A.; SIBLEY, C.M. Current and emerging azole antifungal agents. Clin. Microbiol. Rev., v. 12, p. 40-79, 1999.

SHIN, J.H.; SHIN, D.H.; SONG, J.W.; KEE, S.J.; SUH, S.P.; RYANG, D.W. Electrophoretic karyotipe analysis of sequential Candida parapsilosis isolates from patients with persistent or recurrent fungemia. J. Clin. Microbiol., v. 39, p. 12581263, 2001.

SILVA, V.; CABRERA, M.; DÍAZ, M.C.; ABARCA,C.; HERMOSILLA,G. Prevalência de serotipos de Candida albicans en aislamientos de hemocultivo en Chile y primer caso de candidemia por candida dubliniensis. Rev. Iberoam. Micol., v. 20, p. 46-51, 2003.

SILVA, V.; DIAZ, M.C.; FEBRE, N.; CHILEAN INVASIVE FUNGAL INFECTIONS GROUP. Invasive fungal infections in Chile: a multicenter study of fungal prevalence and susceptibility during a 1-year period. Med. Mycol., v. 42, p. 333-339, 2004.

SILVA, M.R.R.; COSTA, M.R.; MIRANDA, A.T.B.; FERNANDES, O.F.L.; COSTA, C.R.; PAULA, C.R. Evaluation of Etest and macordiluition broth method for antifungal susceptibility testing of Candida sp strains isolated from oral cavities of AIDS patients. Rev. Inst. Med. Trop. S. Paulo, v. 44, p. 121-125, 2002.

SINGH, A.; GOERING, R.V.; SIMJEE, S.; FOLEY, S.L.; ZERVOS, M.J. Application of molecular techniques to the study of hospital infection. Clin. Mcrobiol. Rev., v. 19, p. 512-530, 2006.

SOLL, D.R. The ins and outs of DNA fingerprinting the infectious fungi. Clin. Microbiol. Rev., v. 13, p. 332-370, 2000.

ST GERMAIN, G.; BEAUCHESNE, D. Evaluation of the MicroScan Rapid Yeast Identification panel. J. Clin. Microbiol., v. 29, p. 2296-2299, 1991.

STAIB, P.; MORSCHHAUSER, J. Chlamydospore formation on Staib agar as a species-specific characteristic of Candida dubliniensis. Mycoses, v. 42, p. 521-524, 1999. 
SULLIVAN, D.J.; WESTERNENG, T.J.; HAYNES, K.A; BENNET, D.E.; COLEMAN, D.C. Candida dubliniensis sp. nov.: phenotypic and molecular characterization of a novel spcies associated with oral candidosis in HIV-infected individuals. Microbiol., v. 141, p. 1507-1521, 1995.

SULLIVAN, D.J.; HAYNES, K.; BILLE, J.; BOERLIN, P.; RODERO, L.; LLOYD, S.; HENMAN, M.; COLEMAN, D. Widespread geographic distribution of oral Candida dubliniensis strains in human immunodeficiency virus-infected individuals. J. Clin. Microbiol., v. 35, p. 960-964, 1997.

SULLIVAN, D.; COLEMAN, D.Candida dubliniensis:characteristics and identification. J. Clin. Microbiol., v. 36, p. 329-334, 1998.

SUlLIVAN, D.J.; MORAN, G.; DONNELLY, S.; GEE, S.; PINJON, E.; MCCARTAN, B.; SHANLEY, D.B.; COLEMAN, D.C. Candida dubliniensis: an update. Rev. Iberoam. Micol., v. 16, p. 72-76, 1999.

TAN, A.L.; WANG, G.C.Y.; CHIU, Y.W. Candida dubliniensis infection. Singapure Emerg. Infect. Dis., v. 8, p. 445-446, 2002.

TAVANTI, A.; DAVIDSON, A.D.; GOW, N.A.R.; MAIDEN, M.C.J. Candida orthopsilosis and Candda metapsilosis spp. Nov. to replace Candida parapsilosis groups II and III. J. Clin. Microbiol., v. 43, p. 284-292, 2005.

TYLOR, J.W.; HARRER, T.; PSCHEID, E.; SCHWEIZER, A.; ROLLINGHOFF, M.; SCHROPPEL, K. Surveillance of nosocomial transmission of Candida albicans in an intensive care unit by DNA fingerprinting. J. Hosp. Infect., v. 55, p. 283-289, 2003.

TINTELNOT, K.; HAASE, G.; SEIBOLD, M.; BERGMANN, F.; STAEMMLER, M.; FRANZ, T.; NAUMANN, D. Evaluation of phenotypic markers for selection and identification of Candida dubliniensis. J. Clin. Microbiol., v. 38, p. 1599-1608, 2000.

TORTORANO, A.M. et al. Epidemiology of Candidaemia in Europe: results of 28month European Confederation of Medical Mycology (ECMM) Hospital-Based surveillence study. Eur. J. Clin. Microbiol. Infec. Dis., v. 23, p. 317-322, 2004.

VAN HAL, S.J.; STARK, D.; HARKNESS, J.; MARRIOTT, D. Candida dubliniensis meningitis as delayed sequela of treated Candida dubliniensis fungemia. Emerg. Infect. Dis., v. 14, p. 327-329, 2008.

VOSS, A.; KLUYTMANS, J.A.J.W.; KOELEMAN, J.G.M.; SPANJAARD, L.; VANDENBROUCKE-GRAULS, C.M.J.E.; VERBRUGH, H.A.; VOSS, M.C.; WEERSINK, A.Y.L.; HOOGKAMP-KORSTANJE, J.A.A.; MEIS, J.F.G.M. Occurance of yeast bloodstream infections between 1987 and 1995 in five Dutch university hospitals. J. Clin. Microbiol. Infect. Dis., v. 15, p. 909-912, 1996. 
WANGER, A.; MILLS, K.; NELSON, P.W.; REX, J.H. Comparison of Etest and National Committee for Clinical Laboratory Standards broth macrodilution method for antifungal susceptibilty testing: enhancedability to detect amphotericin-resistant Candida isolates. Antimicrob. Agents Chemother., v. 39, p. 2520-2522, 1995.

WARREN, N.G.; HANZEN, K.C. Candida, Cryptococcus, and others yeast of medical importance. In: MURRAY, P.R. et al., eds. Manual of Clinical Microbiology. 7th ed. Washington, DC: ASM Press, 1999. p. 1184-1199.

WEEMS, J.J Jr. Candida parapsilosis: epidemiology, pathogenicity, clinical manifetations, and antimicrobial susceptibility. Clin. Infect. Dis., v. 14, p. 756-766, 1992.

WENZEL, R.P. Nosocomial candidemia: risk factors and attributale mortality. Clin. Infect. Dis., v. 20, p. 1531-1534, 1995.

WENZEL, R.P.; GENNINGS, C. Bloodstream infections due to Candida species in the intensive care unit: identifying specially high-risk patients to determine prevention strategies. Clin. Infect. Dis., v. 15, p. S389-S393, 2005.

WEY, S.B.; MORI, M.; PFALLER, M.A.; WOOLSON, R.F.; WENZEL, R.P. Risk factors for hospital-acquired candidemia. A matched case-control study. Arch. Intern. Med., v. 149, p. 2349-2353, 1989.

WHITE, T.C.; MARR, K.A.; BOWDEN, R.A. Cellular and molecular factors that contribute to antifungal drug resistance. Clin. Microbiol. Rev., v. 11, p. 382-402, 1998.

WINGARD, J.R. Importance of Candida species other than C. albicans as pathogens in oncology patients. Clin. Infect. Dis., v. 20, p. 115-125, 1995.

WILLIS A.M.; COULTER W.A.; SULLIVAN D.J.; COLEMAN D.C.; HAYES J.R.; BELL P.M.; LAMEY P.J. Isolation of Candida dubliniensis from insulin-using diabetes mellitus patients. J. Oral Pathol. Med., v. 29, p. 86-90, 2000.

YANG, C.W.; BARKHAM, T.M.S.; CHAN, F.Y.; WANG, Y. Prevalence of Candida species, including Candida dubliniensis, in Singapore. J. Clin. Microbiol., v. 41, p. 2003.

YANG, Y.L.; LI, S.Y.; CHENG, H.H.; LO, H.J. Susceptibility to amphotericin B and fluconazole of Candida species in TSARY 2002. Diag. Microbiol. Infect. Dis., v. 51, p.176-9-183, 2005.

YUCESOY, M.; MAROL, S. Performance of CHROMAGAR candida and BIGGY agar for identification of yeast species. Ann. Clin. Microbiol. Antimicrob., v. 29, p. 2-8, 2003. 
YEE-CHUN CHEN, M.M.; SHAN-CHWEN CHAF, M.D.; CHUN-CHUAN SUN, R.N.; LISE YANG, R.N.; WEI-CHUAN HSIEH, M.D.; KWEN-TAY LUH, M.D. Secular trends in the epidemiology of nosocomial fungal infections at a teaching hospital in Taiwan, 1981 to 1993. Infect. Control. Hosp. Epidemiol., v. 18, p. 366375, 1997.

XU, J.; MILLAR, B.C.; MOORE, J.E.; McCLURG, R.; WALKER, M.J.; EVANS, J.; HEDDERWICK, S.; McMULLAN, R. Comparison of API 20C with molecular identification of Candida spp isolated from bloodstream infection. J. Clin. Pathol., v. 55, p. 774-777, 2002.

ZAOUTIS, T.E. et al. Antifungal susceptibility of Candida spp. isolated from pediatric patients: a survey of 4 children's hospitals. Diag. Microb. Infect. Dis., v. 52, p. 295-298, 2005. 
ANEXOS 
Anexo 1 - Protocolo de identificação de leveduras da Seção de Micologia do Departamento de Microbiologia-ICB-USP.

Procedência:

Registro:

Observações:

1.Exame direto:

2.Crescimento em meios usuais:

Crescimento em meios com ácido graxo:

3.Microcultivo e tubo germinativo:

PM:

BL:

MV:

CL:

AR:

TG:

Outros:

4.Ascos e ascósporos:

Positivos:

5.Outras provas

-Síntese amido:

-Produção melanina:

-TTC:

6.Auxanograma

$\mathrm{KNO}_{3}$

PEP

glicose:

inositol:

sacarose:

lactose:

dulcitol:

rafinose:

celobiose:

melibiose:

trealose:

ramnose:

maltose:

xilose:

7.Zimograma

glicose:

lactose:

maltose:

sacarose:

Diagnóstico: 